\title{
New Information Reported under HMDA and Its Application in Fair Lending Enforcement
}

Robert B. Avery and Glenn B. Canner, of the Division of Research and Statistics, and Robert E. Cook, of the Division of Consumer and Community Affairs, prepared this article. Shannon C. Mok and Caitlin $G$. Coslett provided research assistance. Patricia J. Dykes and Sylvia A. Fretana assisted in preparing the 2004 HMDA data for analysis.

Most lending institutions with offices in metropolitan statistical areas are required by the Home Mortgage Disclosure Act of 1975 (HMDA) to disclose information to the public about applications for home loans and the home loans that they originate or purchase during each calendar year. The law's requirements arose from concerns that, in some cases, lenders were contributing to the decline of certain neighborhoods by failing to provide adequate home financing to qualified applicants on reasonable terms and conditions. The disclosure of lending activity is intended to help determine whether lenders are adequately serving their communities' housing finance needs, to facilitate enforcement of the nation's fair lending laws, and to guide investment activities in both the public and the private sectors. HMDA is implemented by the Federal Reserve Board's Regulation $\mathrm{C}$.

Underlying HMDA's disclosure requirements is a presumption that more publicly available information will improve market performance and help prevent market failures. The data reported under HMDA are certainly extensive: Taken together, the 8,853 lenders covered by the law as of the end of 2004 are estimated to have accounted for about 80 percent of home loans extended that year.

The Congress has amended HMDA on several occasions to extend the reach of the law to more lenders and to expand the types of information that must be disclosed. Amendments passed in 1989 have been the most sweeping to date. They require that lenders disclose the disposition of each application they process for home loans and the income, race, ethnicity, and sex of the individuals applying for the

\footnotetext{
Note: Gregory Elliehausen, of the Credit Research Center of Georgetown University, prepared a special analysis for this article.
}

loans. As this new information became available, it revealed wide differences in rates of approval of loan applications across racial and ethnic lines and thereby heightened concerns about whether lending decisions complied with the nation's fair lending laws. The disclosures triggered a continuing debate about the proper interpretation of the data and the significance of the differences in lending decisions. Many lending institutions have responded to the concerns raised in the debate by adopting new loan-underwriting procedures to help ensure fair treatment of all applicants and by initiating a wide variety of community outreach and affordable lending programs intended to benefit minority borrowers and lower-income individuals and neighborhoods.

In 2002, in its most recent review of Regulation C, the Federal Reserve Board made a number of important changes to the disclosure requirements that substantially increase the types and amount of information made available through HMDA. ${ }^{1}$ The revisions are intended to better advance the purposes of the law by keeping the regulation in step with recent developments in home-loan markets and by incorporating the revised standards of classification for the collection of information on race and ethnicity as established by the Office of Management and Budget (OMB).

Most of the recent changes in the information that is required to be reported under HMDA apply to data relating to loans extended in 2004. Individual lenders covered by HMDA were required to make their 2004 data available to the public beginning on March 31, 2005. However, only the September 2005 release of the data will have been comprehensively checked by the supervisory agencies for the errors and omissions that are detectable from a review of the data.

Perhaps the most important change to Regulation $\mathrm{C}$ is the requirement that lenders now disclose pricing (interest rates and fees) for loans with prices

1. Se: IIom: Mortgage Disclosur: Act (12 U.S.C. 2801). RagulaLion C (12 C...R. pt. 203), and the staff commentary accompanying Resulation C. (12 C.F.R. pL. 203, Supp. I). The Foard's revisions to Rogulation C. that are the toous of this articls were issued in 2002. Soe the following issues of lederal Register (2002). Fol. 67: lidoruary 15, p. 7222; May 8, p. 30771: and Tune 27, p. 43218; and Federel Regisfer (2003), vol. 68 (May 28), p. 3].589) 
above designated thresholds. Loans with prices above the thresholds are referred to here as "higher-priced loans." Other important new information being reported under the revised regulation is whether the loan is a first lien, a junior lien, or unsecured (characteristics referred to here as a loan's lien status), whether it is secured by a manufactured home, and whether it is subject to the protections of the Home Ownership and Equity Protection Act of 1994 (HOEPA). These new pieces of information allow for a better understanding of lending activity in the higher-priced segment of the home-loan market, a segment that was virtually nonexistent a decade or so ago and is now a substantial part of the market. The growth of this market segment, while affording some consumers greater access to credit, has been accompanied by concerns about abusive lending practices, often referred to as "predatory lending."' 2 These concerns lend importance to a better understanding of the higher-priced segment of the market and a greater ability to monitor the activities of the individual lenders involved in it.

This article presents a first look at the greatly expanded 2004 HMDA data and considers some of their implications for the continuing concerns about fair lending. ${ }^{3}$ The analysis highlights some key relationships revealed in an initial review of the types of data that are new for 2004. Some parts of the analysis focus on nationwide statistics, and others examine patterns across groups of lenders, loan products, and various groupings of applicants, borrowers, and neighborhoods. The authors explore, in particular and in some depth, the strengths and limitations of the information on loan pricing.

We also describe how the Federal Reserve uses the HMDA data as part of a screening tool to facilitate

2. The Federal Reserve has adopled no specilic cle linition of predatory lending, but the lem is oflen considered to encompass at variety of lending prastices involving traud. deception. or unfairness. Soms prodatory lending practios are illogal; others, although legal, are still comsitered abusive in crtain circumstances. Some of the praclices considered questionable or in some casts illegal include (1) making lowe that are based on the asset value of the collatial but are unatordable given the consumer's atbility to pay the obligations (2) inducing repeated refinancing accompanied by high fees that provide no material bentit to the consumer (sometimes reterred to as "loant flipping"); (3) inducing the consumer, through decption or fraud, to accept loan atd-ons, such as single-premium credil insurance; (4) "stecring" borrowers qualified for lower-rate loans into higher-priced loans; and (5) purposty owerestimating the walue of the collateral to oferstate available etjuity or incluce a comsumer lo pay an inllated price for a home.

3. Ifor axtitional information. see Board of Governors of the lisderal Reserve System, Department of Housing and I'Tban Development. Federal Theposil Insurance Conporalion, Nalimal Credit TInion Administration. Office of the Comptroller of the Currency, and Otice of Thritt Suprervision (2005), "Agencios Announce Answars to lithquemtly Asked Questions ahout New HMTJA Dalat," press release; March 31 , ww federalreserve.gov/hoardecs/press/all/2005/. the enforcement of the fair lending laws. In this regard, we discuss the way the expanded HMDA data, particularly the information on loan pricing, enhance the utility of the screening tool. At the same time, we emphasize that, although these data present valuable new opportunities for researchers and others to learn more about the home-loan market and for the regulatory agencies to improve the enforcement of fair lending laws, the data are not sufficient by themselves for drawing conclusions about the fairness of the lending process or the activities of any individual lender. For example, credit history scores and other factors not included in the HMDA data can be critical in determining loan prices. With regard to this issue, we collaborated with researchers at the Credit Research Center of Georgetown University, which has data on credit history scores and other loan-level factors relevant to loan pricing. The loan-level data were supplied to the Credit Research Center by a small group of lenders that are covered by HMDA and are active originators of loans in the higherpriced segment of the home-loan market.

Our examination of the 2004 data also focuses on the newly reported information about loans on manufactured homes. The disposition of applications for loans to buy, refinance, or improve such units has an important influence on the pattern of denial rates of all loans reported under HMDA. We also discuss the new information on HOEPA-related lending and certain requests for pre-approvals of home-purchase loans and assess their overall significance in the market. Finally, in the article's summary and conclusions, we review our key findings and emphasize that users of the data should exercise particular caution in drawing conclusions about lending patterns from HMDA data alone.

\section{THE REQUIREMENTS OF REGULATION C}

The Federal Reserve Board's Regulation C, which implements HMDA, applies to most depository institutions (commercial banks, savings institutions, and credit unions-hereafter, "banks") with a home or branch office in a metropolitan area. Banks that are exempt from Regulation C are small (currently those with assets of less than $\$ 34$ million), or are not in the home-lending business, or have offices exclusively in rural (nonmetropolitan) areas. ${ }^{4}$ Regul i-

4. Although coverage of limancial inslitulions under HNT)A is limited to those with otices in motropolitan statistical areas, covered institutions must repot on all their homs-lending activitios whother the properties involyed in the loan are located in a melropolitan or nonmetropolitan area. 
tion $\mathrm{C}$ also extends to mortgage and consumer finance companies-hereafter, "mortgage companies"whether such companies are independent or are subsidiaries of banks or affiliates of bank holding companies. Coverage of mortgage companies applies mainly to those that are active in the home-loan market - that is, those that extend 100 or more homepurchase or home-refinancing loans per year and operate in at least one metropolitan area. ${ }^{5}$

The HMDA data include information about applicants and borrowers, the home-loan products they seek, the disposition of their requests for credit, and details about the location of the property that relate to the application. For information about the channels through which the HMDA data are released and for a description of the data that were required of lenders before the 2002 revisions, see box "Distribution of HMDA Data and Pre-2004 Requirements of Regulation C."

\section{The New Reporting Requirements}

The 2002 revisions to Regulation C are intended to improve the quality, consistency, and utility of the data reported under HMDA; they are also intended to ease regulatory burden, primarily by clarifying and simplifying parts of the regulation. The new requirements

- expand coverage to more nondepository lenders

- streamline the definitions of refinancing and homeimprovement loan

- revise the definition of application to include certain requests for pre-approvals (however, in this article, applications are defined as being for a loan on a specific property; they are thus distinct in our analyses from requests for pre-approval, which are unrelated to a specific property)

- mandate for the first time the collection of lien status; property code (to distinguish between oneto four-family dwellings that are site-built and those that are manufactured homes); loan pricing; and HOEPA status

- incorporate changes to the rules on collecting and reporting information on race and ethnicity to conform to guidance issued by the $\mathrm{OMB}$

5. For the details of the coverage rules and for additional informattion about the data collsction and reporting requirements. swe A Gutele to HWDA Reponting: (Terting It Right! published annually by the Federal Financial Instilutions Fxamination Council (www. fiec.gowf hmda/guicle.htm).
- require lenders to request the race, ethnicity, and sex of prospective borrowers who apply by mail, Internet, or telephone

- revise the categories that identify the type of institution to which loans are sold

The disclosure of additional data and the revised definitions for some currently reported items serve several purposes. For example, the revised definition of refinancing is intended to reduce inconsistency in the data and to simplify reporting." Some of the new data items - such as lien status and identification of loans for manufactured homes-allow more-precise differentiation among loan products and consequently reduce the possible analytical biases that arise when dissimilar loan products are grouped together. To ensure that nondepository institutions that are active home lenders are subject to the same reporting regime as are other lenders, coverage rules were changed by adding an annual dollar-volume threshold of $\$ 25$ million of home-loan originations to the current criterion of 10 percent of total loan originations measured in dollars.

Pricing information increases the scope of analysis of HMDA data in support of fair lending enforcement and makes possible an assessment of pricing patterns in the higher-priced segment of the home-loan market. In addition, designation of HOEPA status can be used to identify lenders involved in that type of lending, to measure its incidence in the market, and to aid in fair lending evaluations and HOEPA compliance. Finally, the new information on requests for pre-approvals provides more data on consumers' experiences in the early stages of shopping for a loan to buy a home, a phase of the loan process that has heretofore gone largely unreported, and thus should also facilitate fair lending enforcement.

\section{Transition Rules}

To minimize reporting burden and to help ensure the quality and usefulness of the expanded data, the Federal Reserve established transition rules for HMDA compliance that generally did not require lenders to collect some of the new information for requests for pre-approval and applications submitted before January 1, 2004. Among the new information

6. Reporting institutions hat been allowed to choose from four sernarios in decicling which relinancings $t o$ report. The new rules dotine a retinancing simply as a sceured home low that satistios and replaces another sceurat home loan by the same borrower. The reporting of home equily lines of credil (extended for any purpose) is yolunLary: 


\section{Distribution of HMDA Data and Pre-2004 Requirements of Regulation C}

Under the Home Mortgage Disclosure Act (HMDA), lenders use a "loan/application register" (HMDA/LAR) to report information annually to their federal supervisory agencies for each application and loan acted on during the calendar year. Lenders must make their HMDA/LARs available to the public by March 31 following the year to which the data relate, and they must remove the two date-related fields to help preserve applicants' privacy ${ }^{1}$

The Federal Financial Institutions Examination Council (FFIEC), acting on behalf of the federal supervisory agencies, compiles the reported information and prepares an individual disclosure statement for each institution-one for each metropolitan statistical area (MSA) and metropolitan division (MD) in which it has offices-as well as aggregate reports for all covered lenders in each MSA and other reports. ${ }^{2}$ The disclosure and aggregate reports are detailed tables of data on individual loans and applications.

The disclosure statements and reports are available to the public at the FFIEC website for HMDA (www.ffiec.gov/ hmda), from the covered lenders themselves, and from depositories (such as public libraries and other government offices) in each MSA. In addition, a copy of the HMDA/ LAR for each institution is available to the public on CD-ROM for a nominal charge. The FFIEC also makes available a copy of the file of population characteristics of each census tract covered by the tables on individual institutions and by the aggregate tables. The 2004 census tract file is derived from the 2000 decennial census. MSA and MD identifiers included on that file are based on the designations of MSAs issued by the Office of Management and Budget. 4

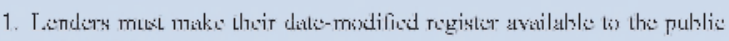

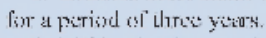

2. MSAs that have a single core with a population of 3.5 million or more

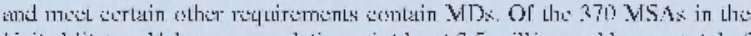
Lnited States, 11 . have a population of at least 3.5 million aud have a total of 29) ML's. Starting with the release of the 20jij LIMDA data, disclosure reports

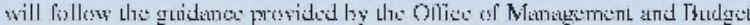
OMBi regarding the appropriate use of statistical-area detinitions; see Ottice

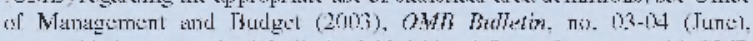
wrw. whil: guidauce, the HHIEC will prepare disclosure reports tor each MSA and MD.

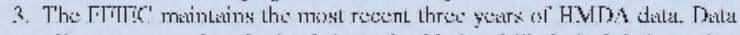
for earlier years cau be obtained from the National lechnical lutormation Center, Springtield, Virginia, www.utis.gov.

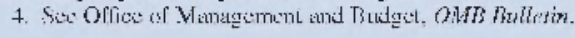

Before the most recent revisions, in 2002, the Federal Reserve Board's Regulation C required lenders to report the following information on home-purchase and homeimprovement loans and on the refinancing of such loans:

For each application or loan

- application date and the date an action was taken on the application

- action taken on the application

— approved and originated

- approved but not accepted by the applicant

- denied (with the reasons for denial-voluntary for some lenders)

— withdrawn by the applicant

- file closed for incompleteness

- loan amount

- income relied on in loan underwriting

- loan type

- conventional

— insured by the Federal Housing Administration

— guaranteed by the Veterans Administration

- backed by the Farm Service Agency or Rural Housing Service

- loan purpose

— home purchase

- refinance

- home improvement

- type of purchaser (if the lender subsequently sold the loan)

For each applicant or co-applicant

- race or ethnicity

- $\operatorname{sex}$

For each property

- location, by state, county, and census tract

- type (one- to four-family dwelling or dwelling with five or more units)

- occupancy status (owner-occupied or nonowneroccupied)

Information is also reported on home loans purchased by an institution during a calendar year. Under the 2002 revisions to Regulation $\mathrm{C}$, additional items became required beginning in 2004. items affected by the transition rules were the data on pricing; the information on whether an application or loan involved a request for pre-approval and on whether the dwelling involved was a manufactured home; and the classifications of race and ethnicity.

Of all applications involving one- to four-family units in the 2004 HMDA data, about 2 million, or 7 percent, were filed before 2004, and thus the data reported on those applications (pertaining to about
1 million loans) might not reflect the new reporting rules. Users of the 2004 data should be aware of this limitation.

To help users of the HMDA data better distinguish loans subject to the transition rules, the Federal Financial Institutions Examination Council (FFIEC) has added a data item to the $2004 \mathrm{CD}$-ROM that contains a copy of the HMDA/LAR for each institution that indicates whether or not an application was 
filed before January 1, 2004 (see box "Distribution of HMDA Data and Pre-2004 Requirements of Regulation C"). Users of the 2004 data can make assumptions or restrict their analysis in various ways to address problems created by the transition rules. For example, in preparing the institution and aggregate MSA disclosure reports for 2004, the FFIEC excluded applications filed before January 1, 2004, from all tables reporting pricing (but not other) information.

The transition rules should have little effect on the data in future HMDA filings. However, because some applications have application filing dates that precede a decision on the application by more than a year, a few applications subject to the transition rules may be included when the 2005 HMDA data are reported in 2006.

\section{Lien Status}

Information on lien status differentiates home loans secured by a first lien, those secured by a junior (second or third) lien, and those not secured. (The last category arises only among home-improvement loans, for which a security interest in a property may or may not be taken.) Knowledge of lien status is basic to credit underwriting because loans secured by first liens have a lower incidence of default than loans secured by junior liens or unsecured loans; consequently, loans secured by a first lien are generally offered at the lowest rates of interest.

The information on lien status serves a number of public policy interests. First, the information improves the measurement of the overall size of the home-loan market and particular segments within that market, such as home-purchase lending. Although HMDA data have always included information about the purpose of a loan, recent market developments have made that information less useful for measuring lending. Today, many home purchases involve both first- and junior-lien loans. The juniorlien loan in such transactions is often used to avoid requirements to purchase private mortgage insurance (PMI) or to avoid exceeding the loan-size limits used by some secondary-market purchasers, especially Fannie Mae and Freddie Mac (see the appendix for more information about PMI and the availability of data on loans backed by PMI). In the past, a loan backed by a junior lien could not be distinguished directly in the home-purchase loan data from one backed by a first lien and was therefore often assumed to represent a separate home-purchase loan rather than to be one of two used to purchase a single property $^{7}$ The expanded HMDA data allow such distinctions to be made and consequently help avoid the double counting of loans in the home-purchase market.

Second, lien status is essential for interpreting loan-pricing information and in conducting fair lending investigations. Regarding fair lending reviews, the historical lack of information on lien status in the HMDA data has hampered analyses focusing on potential differences in the pattern of the disposition of applications because distinguishing properly among loan products using only HMDA data has been difficult or impossible. ${ }^{8}$ Because the use of various loan products and patterns of application disposition can vary across racial and ethnic groups, an inability to distinguish products can lead to spurious correlations and potentially inappropriate conclusions about the fairness of the application of creditunderwriting policies.

\section{Manufactured Home Status}

Available evidence indicates that the credit profiles of individuals seeking loans backed by manufactured homes differ from those of individuals borrowing for site-built homes. ${ }^{9}$ On the whole, loans to purchase manufactured homes involve relatively high credit risk, in part because the buyers of such homes tend to have weaker financial profiles than do those purchasing other single-family properties. This evidence has important implications for denial rates and pricing.

Analysis of past HMDA data implied that lenders denied about 60 percent of all applications for conventional home-purchase loans for manufactured homes, whereas they denied only about 12 percent of

7. One lechnicgue used to identify loans backed by jumior liens was to assume that all loans bolow a given amount wher junior-lion loans. This approach is flawed txcause some homes, incluting many manufactured homes, have low prices and purchasers of these properties otten nexd only a small loan. Similarly, some borrows's maks: substantial down payments when they buy a homs. and in such circumstances, the amoumb of the first-lien loan may he small.

8. Touring some fair lending reviews, lenters hate provicled examincrs with information that has allowed the scparation of tirst and junior lisens.

9. A mamufactured home is a single-family house conslructed under a ficderal building cods: administered by the L.S. Department of Ilousing and Urban Dowelopment (IIUD). The Licdral Manutactured Home Construction and Safely Stanctards (commonty known as the HIT) code) took effect on Tune 15, 1976. The result of fecteral rogulation was to more charly detine mobile homes as buildings ralher than vehicles-although the HTIJ) code imposes stanctards to make sure the units can be transporled by truck to the placement sile. The Ilousing Act of 1980 otficially adoptod this change. mandating that, for homes built under the IIL L) cods. the term matufactsed housing (factory-buil homes) replace the Lerm motrile homes in all federal law and lileralure. 
applications for other conventional home-purchase loans. ${ }^{10}$ Until now, the general inability to accurately distinguish manufactured-homs loans from loans related to site-built homes complicated the determination of whether differences in denial rates across groups of applicants arose from differences in underwriting practices across the groups or simply from different mixes of loan products sought by the groups. Identification of applications and loans involving manufactured homes in the expanded HMDA data allows for more-refined analysis of the sources of different denial rate patterns and for greater understanding of financing activities in this important market segment.

\section{Loan Pricing}

The home-loan market has evolved in a number of important respects over the past decade or so. Traditionally, lenders offered consumers a relatively limited array of products at prices that varied according to the characteristics of the loan and property but not according to the creditworthiness of the borrower. Effectively, borrowers either did or did not meet the underwriting criteria for a particular product, and those who met the criteria paid about the same price. This market characterization may explain why the congressional revisions to HMDA in 1989 focused on the disclosure of data on the disposition of applications rather than on loan prices.

Since then, improvements in information processing and the maturation of a robust secondary market for loans have spurred changes in the home-loan market. Prominent among these changes has been an evolution toward an explicitly risk-based pricing of credit. Now the creditworthiness of individual borrowers can lead to different prices for the same product. Less-creditworthy applicants, or those either unwilling or unable to document their reditworthiness or income, are increasingly less likely to be turned down for a loan; rather, they are offered credit at higher prices.

Borrowers in the higher-priced market generally fall into one of two market segments, "near prime" and "subprime," with individuals in the latter category paying the highest prices because they pose the

10. In the past, loans on manufactured homes were identified using intomation about the lender's main line of business. This proxy is helpful only for lenters focused mainly on mamufactured-home lenting. A large number of other lenders also extend such crectit, but becauss manufactured-home lending doss not constitute: their main line of businss, determining which of their loans involvo manuactured homes has beel impossible. See wwwhuduser.org/dalasets manu.hLml. greatest risk of default. In practice, the dividing line between these two "nonprime" markets is becoming increasingly amorphous, as is the line between the prime (lower-price) and nonprimc markets.

Estimates of the annual volume of subprimc lending vary, but all sources agree that this market has grown substantially in recent years. ${ }^{11}$ One industry source estimates that over the period 1994-2004, the annual dollar volume of subprimin home loans increased from about $\$ 35$ billion to more than $\$ 530$ billion. Consequently, subprime lending is no longer a minor segment of the market. Subprime loans are estimated to have accounted for about 19 percent of all home-loan originations in 2004, up from less than 5 percent in 1994. ${ }^{12}$

As significant pricing variability has emerged in the market, so have concerns about the fairness of creditor decisions in this regard. Little information has been available to assess the merits of these concerns, and only a few fair lending investigations focusing on pricing issues have been pursued by the federal banking agencies or the Department of Justice. In its review of Regulation C that led to the 2002 revisions, the Federal Reserve Board averred the importance of gathering information to facilitate assessments of the fairness of loan-pricing decisions, particularly for nondepository institutions, which are less likely to be subject to periodic fair lending examinations. Recognizing the costs incurred by lenders to comply with such a reporting and disclosure requirement, the Board limited the scope of the regulation to the disclosure of pricing on loan originations (not loans purchased from other entities or applications that did not result in a loan origination) in the higher-priced segment of the loan market and to focus within that segment only on dwellingsecured loans subject to Regulation Z (which does not cover "business purpose" loans-including some loans to individuals who do not intend to occupy the dwelling being financed). ${ }^{13}$

Specifically, the 2002 revisions to Regulation C require the reporting of the spread between the annual percentage rate (APR) on a loan and the rate on

11. Ons methex of stimating the annual volume of subprime loans is hased on a list of subprime lenders that was developed by HITT) and has boen rekased cach yoar since 1993. The number of loans in the IIMDA data originated by lenders on the IIUD list has been used as an estimate of subprime lending volume. The list has also beem used Lo support olher andyses of subprime lending activily. Of the 224 londers on the list for 2003, 191 appoar under the same name and identificalion number as reported in the HMT)A filings for 2004.

12. Fstimales pertain to home loams backed by one- to four-family homs; sce. Inside Mortgags linance Publications (2005), Mortgage Market Statisticat Anmat 2005, 2 Fols. (Bsthesda, Md.: IMl'P).

13. Regulation 7., 226.3(a). The Federal Reserve Foard's Regulation 7. (12 C.F.R. pL. 226) implements the Truth in J, enting AcL. 
Treasury securities of comparable maturity for loans with spreads above designated thresholds. The APR was selected as the measure of the loan's pricing because it was regarded as the best single measure of the "true" cost of a loan. The thresholds for reporting differ by lien status: 3 percentage points for first liens and 5 percentage points for junior liens. To calculate the rate spread, the lender uses the yield on Treasury securities as of the fifteenth day of a given month depending on when the interest rate was set on the loan ${ }^{1+}$

In establishing this disclosure rule, the Federal Reserve sought to select thresholds that would exclude the vast majority of prime rate loans and include the vast majority of subprime loans. The selection of specific thresholds was based on loanprice data from several sources. ${ }^{15}$ The analysis revealed that roughly 98 percent of prime first-lien loans have APRs that would likely fall below the threshold of 3 percentage points for reporting first liens. ${ }^{16}$ The analysis also indicated that this threshold would require reporting for about 98 percent of the subprim loans backed by first liens and that the 5 percentage point threshold would capture about 95 percent of the subprimi loans backed by junior liens. Overall, data from the Annual Housing Survey covering prime, near-prime, and subprimc loans suggested that, in a typical year, the thresholds would fall somewhere in the near-prime range and would require the reporting of about 10 percent of all home loans backed by first liens and about 22 percent of all loans backed by junior liens.

In a given year, various factors may influence the proportion of loans that have prices placing them above or below the pricing thresholds. A change in interest rates can influence the volume and types of loans that exceed the pricing thresholds. With generally rising interest rates, for example, refinancing

14. lior such calculation. the rule directs cretitors to use the fitteenth tay of at given month for any loan on which the interest rate was sot on or atter that day through the fourtionth day of the next month. The relevant date is when the interst rate on the loan was determined, which is oftert, bul norl al ways, set pursuant to a lock-in agrement between the horrower ant the lender. The APR used in the calculations is the one deternined and dischosed to the consumer under section 226.6 or scotion 226.18 of Regulation 2 . To sase reporting hurdens anct to help ensure high-quality data, the FFIFC. makes arailablo a "Rate Sprod Calculator" that lenders can use to determin whother they must report the spmad on a given lon and. if so, what the spreat is; see www.ffiec.gov/ratespreat/flefault.aspx.

15. See the TIS. Census Bureat's 1998 and 1999 Annual Housing Surveys, the lideral Rescrve Boart's 2001 Surby of Consumer Finances, the Fetleral Housing Finance Board's 1999) Mortugage Interest Rate Survey, and tata on subprime lencling from the Credit Resuarch Cienter of Cicorgetown linisisity.

16. Sre Board of Gowernors of the licdoral Roserve System (2002), "Regulatory Amalysis of Proposed Amenciments Lo Reyulation C"." staff memorantum. Tivision of Research and Statistics, Tanuary 15. activity will be reduced, and consequently a larger proportion of loans reported above the thresholds will involve home purchases. Moreover, borrowers who refinance during a period of rising interest rates are likely to differ from those who borrow when rates are falling. When rates are rising, borrowers seeking to refinance their outstanding loans are likely to have more-urgent needs for additional funds that can be raised by a cash-out refinancing or are seeking to lower their total monthly payment obligations by lengthening the terms of their outstanding debt.

Changing interest rates also may affect the proportion of adjustable-rate versus fixed-rate loans originated over the course of a year and thus the mix of loans reported with rates above the threshold. To compensate borrowers for bearing the additional interest rate risk associated with adjustable-rate loans, such loans typically have lower initial APRs than do fixed-rate loans with the same term to maturity. If market participants expect interest rates to rise, these expectations tend to be built into the term structure of interest rates (the "yield curve") and to widen the difference between the initial rates on adjustablerate and fixed-rate loans. This widening can increase the proportion of fixed-rate loans with APRs above the threshold because the APRs for longer-term adjustable-rate loans will not rise as much in such a market as will those for fixed-rate longer-term loans.

\section{HOEPA Status}

Long-standing concerns about predatory lending led the Congress to enact the Home Ownership and Equity Protection Act of 1994, the first federal statute to explicitly target such lending practices. HOEPA, which amends the Truth in Lending Act, applies to closed-end home loans (excluding home-purchase loans) bearing an APR or dollar-amount fees above specified thresholds ${ }^{17}$ The act imposes restrictions on certain loan features, including balloon payments and prepayment penalties, and requires improved disclosures for consumers. HOEPA, like most other federal consumer protection statutes, overrides weaker state laws but permits states to enact stricter rules.

17. Unlike linss of credit. closed-end loans are amortizing-they require lixed momthly payments ayainst both principal and interestand are thus schecluled lo dose at. the end of a given term to maturily, when the balanes will thach zso. A balloon payment might bo: involyed if the amortization schedule leaves a relatively large balance owed at the end of the loams's term. In contrast, a home equily line of credit (IILOC) is a revolving account that prmits borrowing from time to tims at the account holdser's discrotion, up to the amount of the cretit line. IInder a HFJ OC. a comsumer may repatedly pay the balance town to zero and then retraw against the line. 
The Federal Reserve Board, which has authority to modify some of the requirements of HOEPA (implemented by the Board's Regulation Z), made such a modification in 2001 . The 2001 revisions to the regulation lowered the APR trigger for coverage of first-lien loans from 10 percentage points above the comparable-maturity Treasury security to 8 percentage points (the threshold for junior liens was left at 10 percentage points), adjusted the calculation of the dollar-amount trigger for fees to include amounts paid at closing for optional credit insurance products, prohibited or restricted certain practices, and required improved disclosures. ${ }^{1 \xi}$ Although these amendments addressed some concerns, predatory lending continues to some degree. Since 1999 , about thirty states and numerous local governments have enacted laws regarding predatory lending to address certain practices and contract terms. The Congress has also considered amendments to HOEPA to broaden its scope and to preempt state laws, but to date, no final action has been taken.

In its 2002 amendments to Regulation C (the HMDA regulation), the Board required lenders to report whether a loan is subject to HOEPA. In so doing, the Board recognized that obtaining information on the volume and pattern of lending covered under HOEPA would be useful for a better understanding of the size of the HOEPA-related segment of the market and would allow regulators to focus examinations on the loans and creditors posing the greatest concern. The HOEPA status of loans at banks could always be obtained through on-site examinations; but nondepository lenders are not subject to regular examinations, and thus the extent of their HOEPA-related lending has been largely unknown. Moreover, although banks are examined regularly, the collection of data on HOEPA status on the HMDA/LAR is a much more efficient way for the enforce-

ment agencies to obtain the data and allows for some types of analysis to precede an on-site compliance examination.

\section{Requests for Pre-Approvals}

Prospective homebuyer are often asked by sellers to demonstrate that they are likely to qualify for financing. In recent years, many lending institutions have developed pre-approval programs to respond to that request. Such programs typically provide qualified prospective homebuyer : with a binding written com-

18. For further details, see section 226.32 of Regulation 7. mitment to finance their purchase, subject to certain conditions related primarily to the property to be purchased and any changes in their financial circumstances. The request for a pre-approval does not generally identify a specific property so that, if granted, it can be used by the prospective buyer with more than one prospective seller. In the past, the HMDA records did not include data on requests for pre-approvals unless they ultimately resulted in an application related to a specific property. Under the expanded reporting requirements, lenders must also report requests for pre-approval that were denied. Disclosure of denials of pre-approval requests is intended to provide more-complete information on the availability of home financing and to facilitate fair lending enforcement. Lenders have the option of reporting pre-approvals that were granted but not acted on by the consumer ${ }^{19}$

\section{Changes in the Collection of Data Regarding Race and Ethnicity}

The 2004 HMDA data incorporate the revised standards of classification for government collection of information on race and ethnicity as established by the OMB. ${ }^{20}$ Perhaps the most important OMB revision allows individuals to select multiple racial and ethnic identifications, and HMDA reporting rules were modified to conform to these changes. For HMDA data collected before 2004, applicants for credit had no opportunity to designate both race and ethnicity but had to categorize themselves as being of Hispanic origin or as being in one of five racial categories (American Indian or Alaskan Native, Asian or Pacific Islander, black, white, or other). As of 2004, applicants may designate more than one racial category (American Indian or Alaska Native, Asian, black or African American, Native Hawaiian or other Pacific Islander, or white) and may designate one of two ethnicities (either "Hispanic or Latino" or

19. The omly pre-approval programs (owered by HMT)A are those in which the decision to grant or deny the request is basto on a comprehensive cratit undorwriting process in which a linder collocts and reviews the information it typically considers in making credit dwcisions in a traditional application (that is, an application for a specific property). lior a pro-approval program to to coment. the lemeler musl issue binding writlen commilments (subject only lo very limited condilions) for consumers whose requests were granted. 13caust mousts for pre-approval typically do not identity a specitic home for purchase, the HMT)A data to noL show the property location for pre-approvals that do not ultimately result in an application for credit related to a specitic property.

20. So: Uftice of Management and Budget (1997). "Revisions to the Stanctards for the Classilication of Federal T)ata on Race and Funicity" Federal Register vol. 62 (Octobel 30), pp. 58782-90. 
"not Hispanic or Latino"). (Hereafter, for concision, we refer to the category "black or African American" as black and to the category "Hispanic or Latino" as Hispanic.)

The changes regarding race and ethnicity will make it difficult to align the HMDA data for 2004 with those for earlier years. Most important, applicants who in 2003 were classified as Hispanic were not also classified by their race. Consequently, a comparison of lending activity by race between 2004 and earlier years might lead some to conclude that lending to certain racial groups may have changed when, in fact, the only change was in the classification system.

Changes in the Data-Collection Requirements for Sales in the Secondary Market

The secondary market for home loans is the arena in which loans already originated are bought and sold. HMDA requires that, for a given year, covered institutions report the sales of loans that they originated in that year as well the sales of loans that they purchased in that year. For each sale, the institution must also report the type of purchaser.

HMDA data have long been one of the few sources of loan-level information describing secondarymarket activities. The 2004 data are reported using codes that represent revised categories for identifying the secondary-market purchasers. For the first time, the HMDA data identify loans placed in private securitizations, which represent a growing segment of the secondary market. The revisions in the reporting categories are intended to improve the utility of the data.

\section{SUMMARY OF RESULTS FROM THE 2004 HMDA DATA}

For 2004, the FFIEC prepared disclosure statements for 8,853 HMDA-reporting lenders-3,946 commercial banks, 1,017 savings institutions, 2,030 credit unions, and 1,860 mortgage companies. Of the mortgage companies, most $(1,464)$ were independent entities - that is, institutions that were neither subsidiaries of banks nor affiliates of bank holding companies (table 1). The disclosure statements consisted of 72,246 distinct reports, each covering the lending activity of a particular institution in each metropolitan statistical area (MSA) in which it had a home or branch office (table 2). The number of reporting institutions was up 9 percent from 2003, in part
1. Distribution of home lenders covered by HMDA. by type of institution, 2004

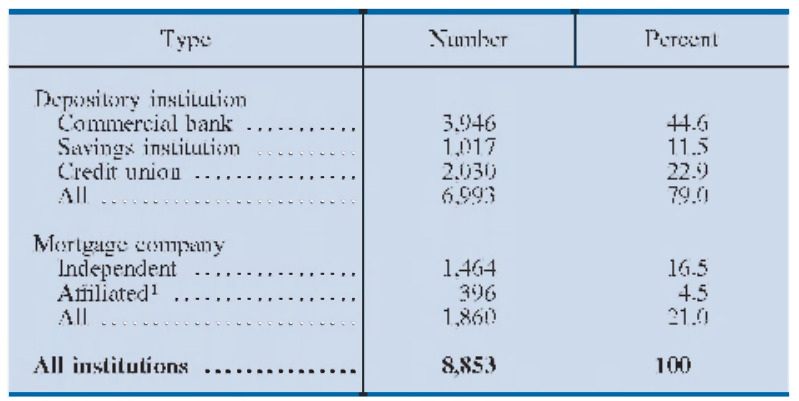

1. Sulsidiary of a depository institution or an aftiliate of a bank holdins amp:any.

Soukct In this and subseguent tables except as noted, Federal Financial Institutions Examination Council, data reported under the llome Mortgage

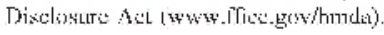

because OMB's revision of MSA boundaries added, on net, 242 previously rural counties to MSAs. ${ }^{21}$

The number of lenders covered by HMDA is large; however, most of these institutions, whether measured by number of reported applications or loans or by asset size, are small. For 2004, 60 percent of reporting institutions provided information on fewer than 250 loans or applications, accounting for 1.7 percent of the reported data (table 3). Sixty-three percent of the reporting banks had assets of less than $\$ 250$ million, and they accounted for only 2.2 percent of the applications and loans in the 2004 HMDA data. ${ }^{22}$

At the other end of the spectrum, the twenty-five lenders reporting the largest number of applications accounted for about 42 percent of all the applications reported in the 2004 data (data not shown in table). If HMDA reporters are further aggregated to their highest level of corporate organization (such as a bank holding company), lending is even more concentrated. The twenty-five largest organizations reporting the largest number of applications accounted for 55 percent of the applications in the 2004 data (data not shown in table).

\section{Volume of Applications and Loans}

For 2004, lenders covered by HMDA reported on roughly 28.1 million home-loan applications (table 2)-9.8 million for purchasing one- to fourfamily homes, 16.1 million for refinancing existing

21. The OMF; changed MSA boundaries Lo encompass 288 previously rural conntiss and to cxclude 46 countiss proviously in MSAs.

22. Becauss of the reporting rules, asset sizs is gencrally a maningful measure of siye omly for depository instilulions. Assets are metasured as of T)ecember $31,2004$. 
2. Home loan and reporting activity of home lenders covered under HMDA, 1990-2004 Number

\begin{tabular}{|c|c|c|c|c|c|c|c|c|}
\hline \multirow{3}{*}{ Yicar } & \multicolumn{6}{|c|}{$\begin{array}{l}\text { Applications received for home loaus, aud home loaus purchased from other leuders } \\
\text { (millisns) }\end{array}$} & \multirow{3}{*}{ R:pirturs } & \multirow{3}{*}{$\begin{array}{l}\text { Lisclosure } \\
\text { l'eparts:- }\end{array}$} \\
\hline & \multicolumn{4}{|c|}{ Appliculiesns: } & \multirow{2}{*}{$\begin{array}{c}\text { T.moms } \\
\text { puraliaked }\end{array}$} & \multirow{2}{*}{ Lotal } & & \\
\hline & $\begin{array}{l}\text { Home } \\
\text { purchase }\end{array}$ & Relinanes & $\begin{array}{c}\text { Hime } \\
\text { improvement }\end{array}$ & Totul 1 & & & & \\
\hline $19901 \ldots$ & 3.27 & 1.017 & 1.16 & 5.51 & 1.15 & 6.606 & 9.332 & 24,041 \\
\hline 1991 & 3.26 & 2.11 & 1.18 & 6.55 & 1.36 & 7.91 & 9.38 & 250.34 \\
\hline $190 \%$. & 3.54 & 5.24 & 1.23 & 1001 & 198 & 12801 & 9,073 & $28,7 \times 2$ \\
\hline 1903. & 4.52 & 7.72 & 1.401 & 13.64 & 1.81 & 15.44 & 9.650 & 35,976 \\
\hline 1964 & 5.20 & 3.80 & 1.69 & 10.60 & 1.48 & 12.17 & 9858 & 38,750 \\
\hline 1005 & 5.51 & 2.70 & 1.75 & 9.96 & 1.28 & 11.21 & 0.539 & 36.611 \\
\hline 1906. & 6.33 & 4.54 & 2.14 & $13 i 11$ & 1.82 & 14.83 & 9.328 & 42,946 \\
\hline 1907. & 6.75 & 5.20 & 2.16 & 14.20 & 2018 & 16.38 & 7.925 & 47,416 \\
\hline 1908. & $7.6 \%$ & 11.42 & 2.104 & 21.43 & 3.23 & 24.65 & 7.830 & 57.264 \\
\hline $1000^{\circ}$ & 8.4 & 9.37 & 2.05 & 19.85 & 3011 & 22.86 & 7832 & 56.966 \\
\hline $20 j 0 i 1 . . . \ldots \ldots \ldots$ & 8.28 & 6.54 & $1.69)$ & 16.81 & 2.40 & 19.21 & 7.713 & 52.776 \\
\hline $2 m p 1$ & 760 & 14.29 & 1.85 & 23.83 & 3.77 & 27.50 & 7631 & 53.0166 \\
\hline 2002. & 7.401 & 17.48 & 1.53 & 26.41 & 4.83 & 31.24 & 7.771 & 50,5106 \\
\hline 2003 & 8.15 & 24.60 & 1.51 & 34.26 & 7.23 & 41.49 & 8.121 & 65.8188 \\
\hline $2 j j j+\ldots \ldots \ldots \ldots$ & 9.79 & 16.10 & 2.201 & 28.13 & 5.14 & 33.27 & 8.853 & 72,246 \\
\hline
\end{tabular}

NotE: Here and in all subsequent tables except tables 3 and 8 , applications exclude requests for pre-approval that were denied by the lender or were accepted by the lender but not acted upon by the borrower.

In this article, applications are defined as being for a loan on a specific property; they are thus distinct from requests for pre-approval, which are not related to a specific property.

home loans, 2.2 million for improving one- to fourfamily dwellings, and 62,000 related to multifamily dwellings (structures for five or more families). Lenders also reported on about 5.1 million loans they purchased from other institutions. In addition, lenders reported on roughly 330,000 requests for preapprovals of home-purchase loans that were either turned down by the lender at the time the preapproval was sought or granted but not acted on by the applicant (data not shown in table). In either case, those 330,000 requests for pre-approval did not reach the stage of an application for a loan for a specific property. ${ }^{23}$ The 2004 volume of applications for refinancing fell about one-third from 2003, primarily because of a rise in interest rates.

\section{Conventional and Government-Backed Loans}

Among the reported applications for loans to purchase owner-occupied one- to four-family homes (both site-built and manufactured), about 90 percent were for conventional loans-that is, loans not involving a government backing for the lendermost of which involve first liens; the remainder were for government-backed forms of credit, mostly

23. Amomg the loan originations in the 2004 thata, about 470,000 wert reported as being initiated through a pro-approval program. This figure liksly understates the number of originations that bogan in pre-approval programs because the transition rules dict not require the reportiny of this item on applications taken before Tanuary 1, 2004.

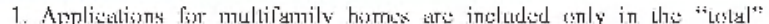
columm; for 2 ilit4 these applications numbered ahout 62 , iliti.

2. A report cover's the mortgage lending activity of a lender in a single motropelilan statisticyl artey in which il had an affice duringe the your.

involving the Federal Housing Administration (FHA) (table 4). An even higher share of applications for refinancings (and home-improvement loans) were for conventional loans, an indication that borrowers with government-backed loans either tend to refinance into a conventional loan or tend not to refinance.

The share of HMDA-reported loans backed by the FHA has been declining over the past several years, from about 16 percent in 2000 to about 8 percent in 2004 (data not shown in tables). New, more flexibly underwritten conventional loan products are likely attracting borrowers that would otherwise seek FHA backing. Among these products are interest-only loans, adjustable-rate products that offer flexible payment options, and products that allow smaller down payments, a wider range of credit histories, and reduced documentation of incomes.

\section{Lien Status}

The 2004 data, which include for the first time information on the lien status of a loan, indicate that a significant minority of reported loans involve junior liens, particularly loans for home purchases. Among the loans to purchase owner-occupied homes, 13 percent involved junior (subordinate) liens (data not shown in tables). ${ }^{24}$

24. The HMTA data do not inclucle a code indicating whelher the junior-lien home-purchase loan reporled in the dala is associated 
3. Distribution of home lenders covered by HMDA, by type of lender and the number of applications they receive, 2004

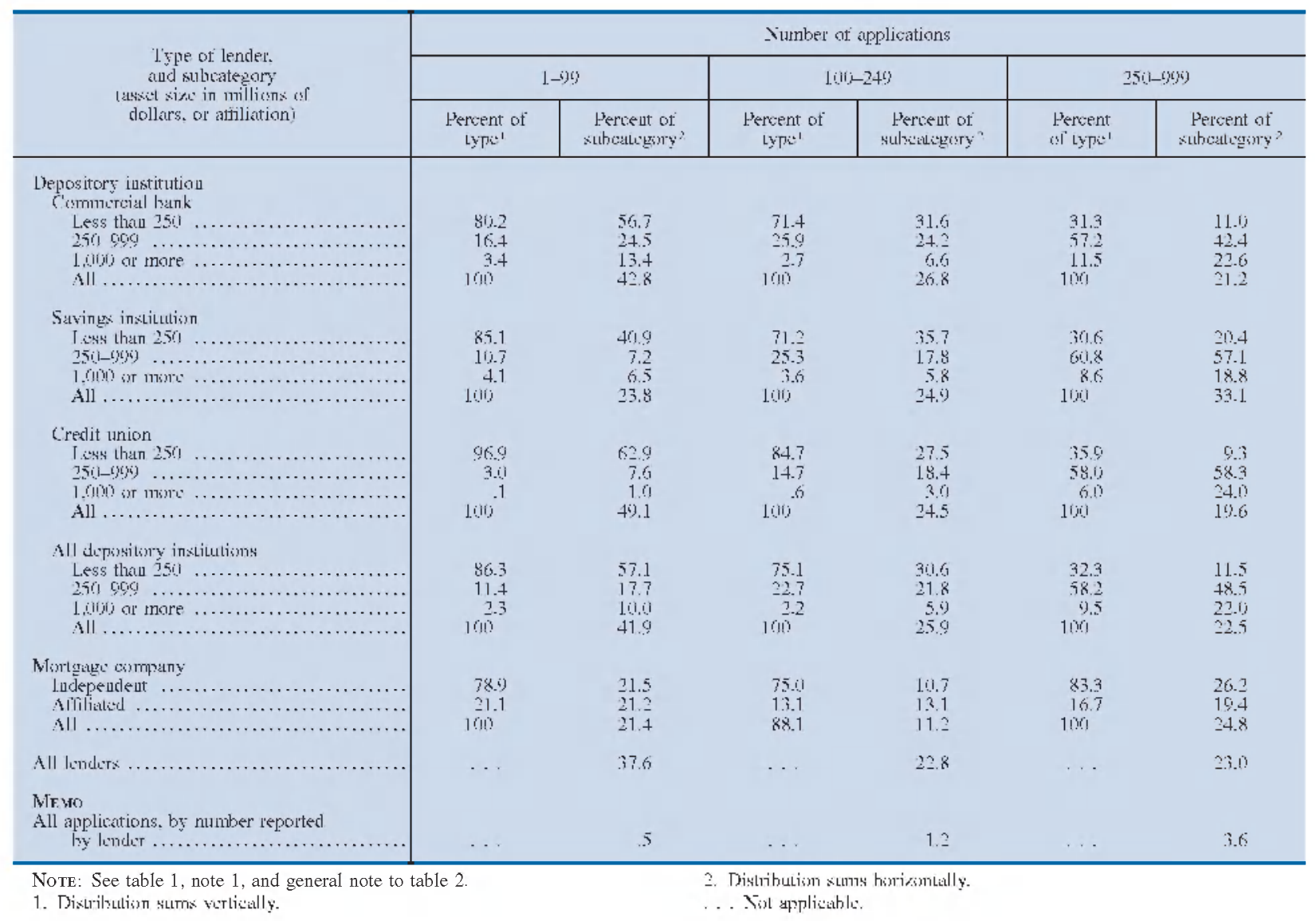

Homebuyers have various reasons for taking out subordinate loans when they purchase their homes. Some are seeking to raise funds to cover the down payments and closing costs of the first-lien loans used to buy their homes. In some cases, funds raised through the subordinate liens allow homebuyers to avoid the requirement to purchase PMI for first-lien loans with high loan-to-value ratios. In other cases, borrowers take out junior-lien loans to keep the amounts borrowed on their first-lien loans within the loan-size limits used by Fannie Mae and Freddie Mac (discussed below).

\section{Owner Occupancy}

Some commentators have attributed part of the strength in housing markets for the past several years

with any particular first-lien loan. The junior-lien loan may be in the reported data, but the first-lien loan may not be. This distinction can arise if, for example, the lender extending the first-lien loan is not covered by HMDA. We estimate that about 62 percent of the juniorlien home loans used to purchase owner-occupied homes in the reported data are likely associated with a reported first-lien home loan of the same lender-these "paired loans" were extended by the same lender in the same census tract to borrowers of the same sex, race, and ethnicity, and the actions taken on each loan in the loan pair were within a couple of days of each other. to a growing number and share of home sales to investors or individuals purchasing second homes as distinct from those who intend to reside in the units being purchased. HMDA reports help document the role of investors in the housing market because the data indicate whether the property to which an application or loan relates is intended as the borrower's principal dwelling (that is, as an owner-occupied unit). ${ }^{25}$ The HMDA data indicate that the share of reported lending for nonowner-occupied purposes remained steady from 1990 through 1995, primarily in the 4.5 percent to 5.5 percent range (whether measured in number of loans or dollar amount of loans), and then began rissing. In 2004 , the nonowneroccupied share of the home-purchase market in terms of number of loans was about 15 percent and in terms of dollar amount was roughly 13 percent (data not shown in tables).

25. An investment propetty is a nomowner-occupied dwelling that is intencled to be contimuously rented. Some nonowner-oceupied units - vacation homss and scoond homes-are for the primary use of the owner and would thus not be considered investment properties. The HMT)A data do not, however; distinguish belween these two types of nonowner-occupiad dwallings. 


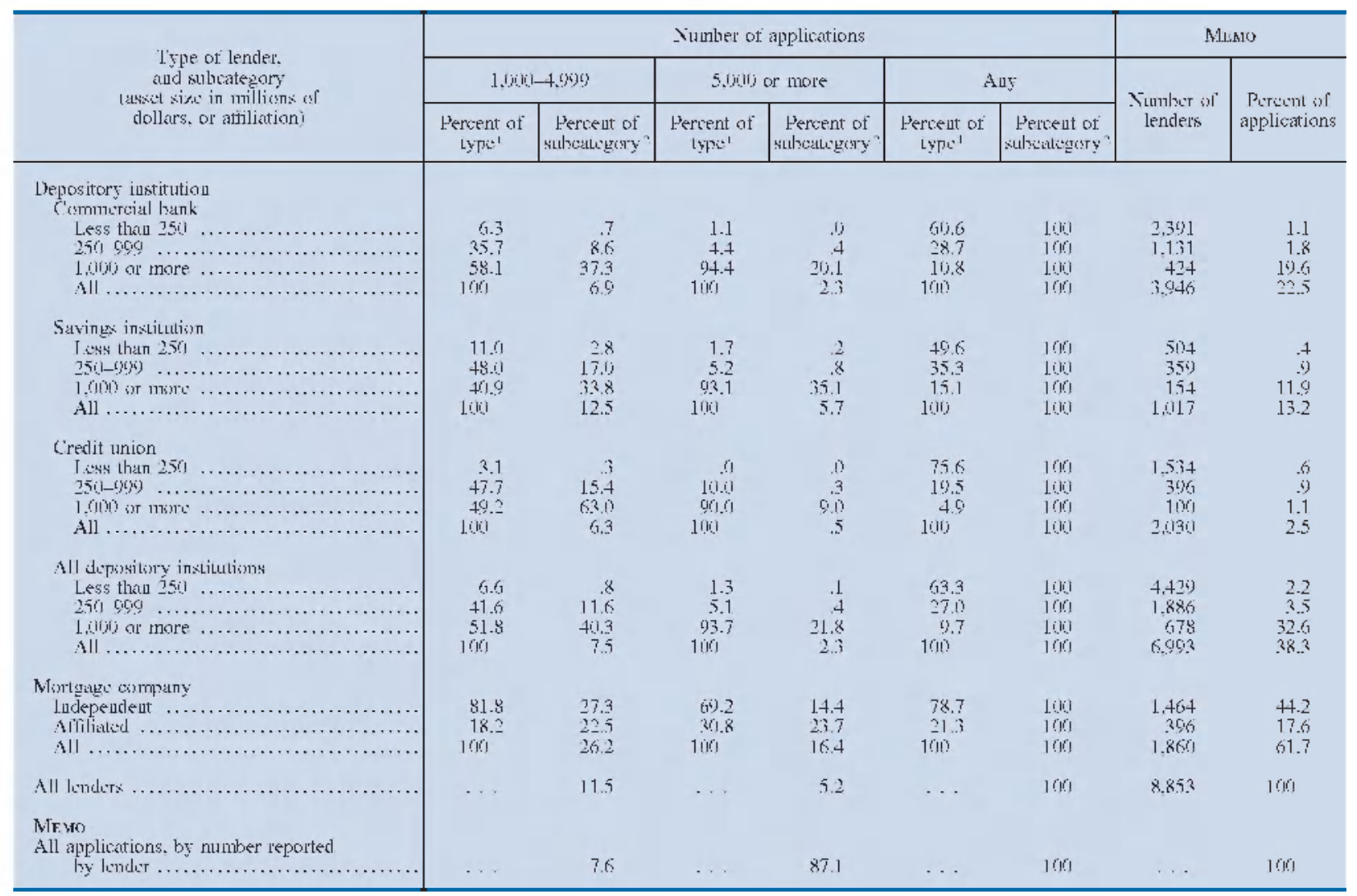

\section{Lender Specialization}

Different types of lending institutions tend to specialize in different types of home loans. Mortgage companies, which extended 54 percent of all the home loans reported in 2004 , accounted for roughly 67 percent of government-backed originations. Depository institutions extended 71 percent of reported homeimprovement loans and about 89 percent of multifamily loans. Commercial banks and mortgage companies together accounted for about 90 percent of loans on manufactured homes in 2004.

\section{Secondary-Market Activity}

HMDA data document the importance of the secondary market for home loans. Of the 20.2 million home loans originated or purchased in 2004 by lenders covered by HMDA, 14.1 million, or roughly 70 percent, were sold in 2004 (data not shown in tables). ${ }^{26}$

26. The HMT)A data tend to undercount the volume of seconctarymarket sales some whal. One reason is that. For example, some loans originated in 2004 will bo sold to a sccondary-market institution in 2005 or later and thus will never be reported as a sale. Another is that, as with olher HMT)A tala, about 20 percent of home loams originated in 2004 wher textended by lenders not covered by IIMDA.
Prominent in the secondary market are government-sponsored enterprises (GSEs) - in particular, Fannie Mae and Freddie Mac. ${ }^{27}$ For the most part, the purchases of Fannie Mae and Freddie Mac in 2004 consisted of conventional loans originated to purchase homes or to refinance existing loans. These two institutions accounted for nearly 35 percent of the loans purchased by secondary-market institutions. Other types of purchasing institutions active in the secondary market include banks ( 8 percent of loans sold), private securitization pools (5 percent), and mortgage and insurance companies ( 9 percent). In some cases, the purchasing institution is affiliated with the originating lender - directly, as a subsidiary, or indirectly, as an affiliate of the holding company that owns the lender. Affiliated institutions accounted for 11 percent of loans sold in the secondary market.

\section{Loans for Manufactured Homes}

In the past, users of HMDA data had no certain way to identify which applications and loans involved

27. GSFs are privalely owned instilutions that blend the characteristics of publis and private institutions. They receive contain bentits from government spomsorship in exchange for their atvancement of certain public policy goals such as homeownership among lowerincoms houscholds and in targetted communitios. 
4. Distribution of home loan applications and home loans, by purpose, lien status, and type of loan and by type and occupancy status of home, 2004

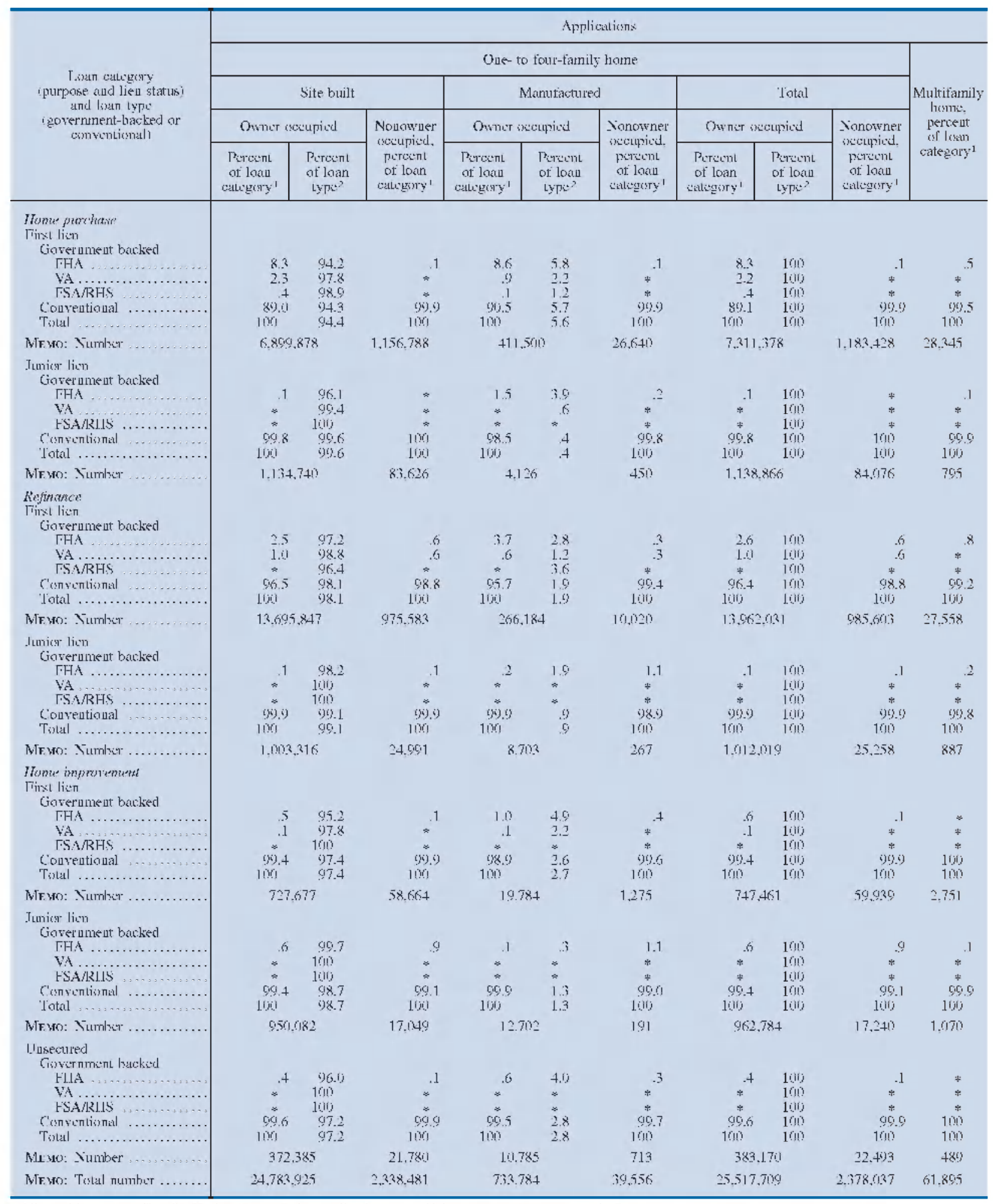

Note: For one- to four-family homes, excludes applications for which occupancy status was missing.

FHA Federal Housing Administration VA Veterans Administration FSA/RHS Farm Service Agency and Rural Housing Service

1. Distribution sums verticaly.

2. Distrilsulism sums hesizomlially

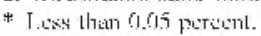




\section{4.-Continued}

\begin{tabular}{|c|c|c|c|c|c|c|c|c|c|c|}
\hline \multirow{5}{*}{ 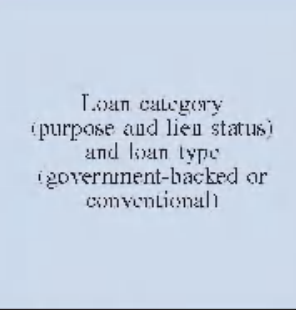 } & \multicolumn{10}{|c|}{ T.cuns } \\
\hline & \multicolumn{9}{|c|}{ One- to four-family home } & \multirow{4}{*}{$\begin{array}{c}\text { Multifamily } \\
\text { homins, } \\
\text { perceut } \\
\text { us lesw } \\
\text { category }{ }^{1}\end{array}$} \\
\hline & \multicolumn{3}{|c|}{ Site built } & \multicolumn{3}{|c|}{ Manutactured } & \multicolumn{3}{|c|}{ Iotal } & \\
\hline & \multicolumn{2}{|c|}{ Owher nocupied } & \multirow{2}{*}{$\begin{array}{l}\text { Nounwuer } \\
\text { 'ocupied, } \\
\text { pereent } \\
\text { of loan } \\
\text { calugery' }\end{array}$} & \multicolumn{2}{|c|}{ Owner iseupied } & \multirow{2}{*}{ 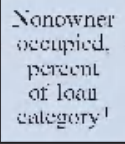 } & \multicolumn{2}{|c|}{ Ownit iscupied } & \multirow{2}{*}{ 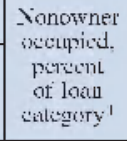 } & \\
\hline & $\begin{array}{l}\text { Percent } \\
\text { of loau } \\
\text { callegery' }\end{array}$ & $\begin{array}{l}\text { Pereent } \\
\text { of loan } \\
\text { type? }\end{array}$ & & $\begin{array}{l}\text { Percent } \\
\text { of loau } \\
\text { calcegery' }\end{array}$ & $\begin{array}{l}\text { Perent } \\
\text { of loau } \\
\text { type? }\end{array}$ & & $\begin{array}{l}\text { Peremt } \\
\text { of loan } \\
\text { taltegrary }\end{array}$ & $\begin{array}{l}\text { Percent } \\
\text { of loau } \\
\text { type }\end{array}$ & & \\
\hline \\
\hline $\begin{array}{l}\text { Tiixt liin } \\
\text { Goverument backed }\end{array}$ & & & & & & & & & & \\
\hline FHA & 8.8 & 95.1 & .1 & 164 & 4.9 & .1 & 00 & 1010 & .1 & .5 \\
\hline VA ........ & 2.6 & 97.6 & $=$ & 2.6 & 2.1 & $*$ & 3.5 & 1iij & $*$ & $*$ \\
\hline ГSARHS & 5 & 900 & $*$ & 2 & 1.0 & $*$ & .4 & 100 & $*$ & $*$ \\
\hline Conventional . & 88.2 & 97.5 & (9), 9 & 81.5 & 3.5 & 99.9 & 8801 & $1010)$ & 99.9 & 99.5 \\
\hline Tixtal $\ldots \ldots \ldots$ & 100 & 97.3 & 1001 & 100 & 2.7 & 100 & 100 & 100 & 1010 & 100 \\
\hline Мған: Tumber & \multicolumn{2}{|c|}{$4,654,243$} & 811,816 & 129.1 & & 15.272 & $4,78.3$ & 393 & 827.188 & 22,247 \\
\hline Tumicr lien & & & & & & & & & & \\
\hline $\begin{array}{l}\text { Goverumeut batked } \\
\text { FHA }\end{array}$ & .1 & 968 & $=$ & 1.4 & 3.2 & * & 0.2 & 100 & $*$ & .2 \\
\hline VA $\ldots \ldots$ & * & 99.1 & $*$ & $*$ & 9 & $*$ & $*$ & 1010 & $*$ & $*$ \\
\hline HSA/RLLS. & $\approx$ & $1011 j$ & $=$ & $\approx$ & $*$ & $*$ & $*$ & iilij & $*$ & $*$ \\
\hline C'senventisnal & 09.8 & 96.7 & 100 & 58.6 & 3 & 100 & 99.8 & 100 & 100 & 008 \\
\hline lotal ....... & 100 & 99.7 & 1001 & 100 & 3 & 100 & $100 j$ & 100 & 100 & $10 j$ \\
\hline NFй: Tumlur & 735 & & 50,362 & & & 285 & 737 & 871 & 501,647 & 62.5 \\
\hline $\begin{array}{l}\text { Reginance } \\
\text { Trivis limen }\end{array}$ & & & & & & & & & & \\
\hline Goverumeut backed & & & & & & & & & & \\
\hline$\Gamma \cdot \mathrm{A}$ & 3.2 & 97.3 & .5 & 6.7 & 2.7 & .2 & 3.2 & 100 & .5 & 8 \\
\hline VA $\ldots \ldots \ldots \ldots \ldots$ & 1.5 & 98.7 & .7 & 1.5 & 1.3 & .4 & 1.5 & $100 j$ & .7 & $*$ \\
\hline ГSA/RHS & $\approx$ & 968 & $\therefore$ & $\approx$ & 3.2 & $\ddot{*}-$ & $\stackrel{*}{*}$ & 100 & $\ddot{0}+2$ & $\approx$ \\
\hline $\begin{array}{l}\text { Genfentionial } \\
\text { lotal } \ldots \ldots \ldots \ldots \ldots\end{array}$ & $\frac{95.4}{10 j i}$ & $\begin{array}{l}98.8 \\
18.7\end{array}$ & $\begin{array}{l}98.8 \\
10 j i\end{array}$ & $\operatorname{lig}_{10 j j} 8$ & 1.2 & $\begin{array}{l}90.5 \\
1 i i j\end{array}$ & $95.3^{2}$ & 100 & 98.8 & 90.2 \\
\hline MFso: Surnlyr & & & 578753 & & $1 \ldots$ & $=1000$ & 1.0. & 10 & $=0,70$ & 100 \\
\hline I Imicr licn & 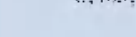 & & . & $\therefore$. & & 3,080 & $1,+\infty$ & 76 & $3 x+, \ldots$ & $-21,0 \mathrm{si}$ \\
\hline Goverumeut backed & & & & & & & & & & \\
\hline ГFА $\ldots \ldots \ldots \ldots$ & * & 980 & * & .1 & 2.0 & .7 & $*$ & 1011? & $*$ & 3 \\
\hline VA & $=$ & 100 & $=$ & $=$ & $*$ & $*$ & $*$ & $1010 j$ & * & $*$ \\
\hline ГSA/RHS & $\approx$ & 100 & $*$ & $*$ & $*$ & $*$ & $*$ & 1000 & $*$ & $*$ \\
\hline Coureutioual & (9), 9 & 99.4 & Loj! & $(99,9)$ & .6 & 99.3 & 9099 & 1010 & 99.9 & $9 \% .7$ \\
\hline Tital $\ldots \ldots \ldots \ldots \ldots$ & 100 & 90.4 & 100 & 100 & 6 & 100 & 100 & $1(01)$ & 100 & 100 \\
\hline Мr.so: Sumbr ....... & 461 & & 11.400 & & & 1.38 & 464 & 463 & 11.568 & 580 \\
\hline $\begin{array}{l}\text { Home inprerlemerat } \\
\text { Fiixt lien }\end{array}$ & & & & & & & & & & \\
\hline $\begin{array}{c}\text { Goverumeut backed } \\
\text { F.HA }\end{array}$ & .7 & 964 & 1 & 11 & 36 & 4 & 7 & 100 & & \\
\hline VA & .1 & 985 & $=$ & .1 & 1.5 & $*^{.7}$ & $i$ & 100 & .1 & * \\
\hline FSARHS & * & 100 & * & $\approx$ & $*$ & $*$ & $*$ & 1010 & $\div$ & $*$ \\
\hline Couventioual ...... & (9).3 & 97.7 & (39.) & 98.9 & 2.3 & 96 & 99.3 & (1010) & 999 & 100 \\
\hline Tistal $\ldots \ldots \ldots$ & 100 & 97.7 & 100 & 100 & 2.3 & 100 & 1010 & 100 & 100 & 100 \\
\hline Мған: Sumber ....... & 352 & 166 & 35,835 & & & 787 & 360 & 315 & 36,622 & 2,0158 \\
\hline Tumiar lien & & & & & & & & & & \\
\hline $\begin{array}{l}\text { Gover umeut backed } \\
\text { THA . . . . }\end{array}$ & 6 & 996 & 6 & 2 & & & .6 & 100 & .7 & 2 \\
\hline $\mathrm{VA} \ldots \ldots$ & $*$ & 100 & $*$ & $*$ & $*$ & $*$ & $*$ & 100 & $*$ & $*$ \\
\hline HSA/RLIS & $\approx$ & $100 j$ & $\approx$ & $\approx$ & $*$ & $*$ & $*$ & $1010 j$ & $\approx$ & $*$ \\
\hline Conquentiontal ... & 99.4 & 98.8 & 09.3 & 90.8 & 1.2 & 97.3 & 90.4 & 100 & 90.3 & 000 \\
\hline 'lotal ............. & 1001 & 98.8 & 100 & 100 & 1.2 & liiij & $1010 j$ & 100 & 1010 & 100 \\
\hline Мraso: Tumber ....... & 393 & 226 & 7,058 & 4. & & 75 & 397 & 825 & 7.133 & 693 \\
\hline $\begin{array}{l}\text { Iusecured } \\
\text { Gisver nmint hacked }\end{array}$ & & & & & & & & & & \\
\hline 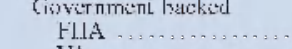 & .4 & 95.4 & .1 & .6 & 4.6 & * & .4 & 1010 & .1 & $=$ \\
\hline VA $\ldots \ldots$ & $*$ & 100 & $\approx$ & $\approx$ & $*$ & $*$ & $*$ & 100 & $*$ & * \\
\hline HSA/RLIS & & & $\approx$ & $*$ & $*$ & $*$ & $*$ & liiij & $*$ & $*$ \\
\hline Conventionnal ....... & 996 & 97.1 & 009 & 00.4 & 29 & 100 & 90.6 & 100 & 99.9 & 100 \\
\hline Tital $\ldots \ldots \ldots \ldots \ldots$ & 100 & 97.1 & 100 & 100 & 29 & 100 & 100 & 1(10) & 1000 & 100 \\
\hline ML310: Number ....... & 147 & & $6,31 j 2$ & & & 267 & 151 & (9ji) & $(0,561)$ & 284 \\
\hline Mrso: 'Tetal numbet ....... & $1,3,149$, & & $1,5011,556$ & 235. & & 22,814 & $13,38.5$ & $49 ?$ & $1,524, .360$ & 48,150 \\
\hline
\end{tabular}


manufactured homes. To help overcome this limitation, the Department of Housing and Urban Development (HUD) produced annually a list of reporting institutions (typically about twenty) that it believed were primarily in the business of extending such credit. ${ }^{28}$ Users of the HMDA data often relied on the HUD list to identify, albeit imperfectly, loans and applications related to manufactured homes. This practice had its own limitations-it could not be used to identify applications and loans related to manufactured homes reported by lenders not on the HUD list, and users often assumed that all loans by the lenders on the list were for manufactured homes when some were not. The expanded HMDA data resolve this problem by explicitly including a code to identify applications and loans for manufactured homes. For background information on manufactured homes, see box "Manufactured Homes in the U.S. Housing Market."

Loans for manufactured homes entail more credit risk than do most other forms of credit extended to consumers. ${ }^{29}$ For example, the proportion of loans for manufactured homes that are thirty days or more past due is far higher than for most other consumer credit products and is about twice the rate for conventional loans secured by one- to four-family homes. ${ }^{30}$ In part, the elevated credit risk arises from more uncertainty about whether the collateral backing the loan will retain its original value. Much of the credit risk arises from the poorer credit history profiles of the typical borrowers in the manufactured-hom loan market compared with those in the site-built homeloan market.

An individual's credit history score (a statistical characterization of an individual's creditworthiness based exclusively on information in a credit record maintained by a credit-reporting agency) is a com-

28. Ser www.hutuser.ory/dlatasel.s/manu.html.

29. Unless otherwist indicatid. intomation in this section is derivat from the following sources: U.S. Burcau of the Consus (for HITD), American Housing Survey (Comerly the Anmual Housing Survey and the Resitemlial Finance Survey wwwhuduserory datassts/pdrdatas.html; Manufactured Ilousing Institut: 2004 , www, manutacturedhousing,ory: and UIS. Consus Burcau 2000 wnsus. www.census.gov/matinfwww/cen2000.htm7. Tuformation on the default rexpericnes regarding loans scourd by manutactured homes and on the eredit history scores of individuals were derived from the Jume 30, 2003, credit recorts of a malionally representatize sample of approximately 300,000 inclivicluals (with all persomal identifyine information romoved; the sample was obtained by the lisderal Reserve Board from one of the three national credit-reportiny atsencies. Ser Robert F. Avery, Paul S. Calem, and Glenn B. Camner (2004) "Credit Roport Acuracy and Acoss to Credit." Federat Reserve Bulletils. vol. 90 (Summer), pp. 297-322.

30. Ser American Fiankers Association. Comanuer Creali Detinquency Bulleisin. wwita.com.

\section{Manufactured Homes in the U.S. Housing Market}

More than 23 million individuals, or roughly 8 percent of the U.S. population, live in manufactured housing. Typically, about 10 percent to 20 percent of all construction starts for single-family housing each year are for manufactured homes. Most manufactured homes are assembled in factories, shipped to a home site, and never moved once installed. Nearly 80 percent of all the manufactured homes are owner occupied, a rate more than 10 percentage points higher than that for site-built homes.

Manufactured housing is a significant source of affordable housing. The average new unit cost about $\$ 55,000$ in 2003 , although prices varied, averaging about $\$ 32,000$ for single-section homes and nearly $\$ 60,000$ for multisection ("double wide") units (excluding land costs). Because the price of a manufactured home is generally lower per square foot than that of a site-built home, the manufactured home is particularly attractive to households with lower incomes. The average annual income of households owning manufactured homes is less than half that of those owning site-built homes and about the same as that of households that rent their homes.

mon metric of credit risk. ${ }^{31}$ Among individuals who have manufactured-hom loans (whether home loans or, as is the case for most manufactured homes, personal-property loans), the average credit history score as of June 30, 2003, was 666, a score nearly 70 points lower than the average among individuals with loans secured by one- to four-family site-built homes. Moreover, nearly 25 percent of the individuals with loans secured by manufactured homes had credit history scores below 600 , a threshold that is often associated with high-risk lending, compared with only about 5 percent of the individuals with loans backed by site-built units.

Lenders recognize the elevated risks related to loans backed by manufactured homes and factor these risks into the interest rates they charge borrowers. ${ }^{32}$ Lender caution is also reflected in the very high denial rates on applications for loans backed by manufactured homes.

31. To facilitate this discussion, we have adjusted the credit history scores assigned to the individuals in the lederal Reserve samplo of 300,000 credil records (see text note 30 ) 10 match the tistribulion of the more-farniliar FICO ctedlit hisklory scores developed by Fair Isade corporation, for which intormation is publicly avalabls. Sor www-mylicosom/nylico/CredilCentral/ScoringWorks. asp.

32. Tn recent years. the manufactured-home lending inclustry has ben adrersely attected by the exessive protuction of units in the late 1990 s and the reliance on the relaxed credit underwriting that acompanied the sales of these units. See Neil J. Morse $(2004)$. "MamufacLuring the Tream," Morrgage Panking (August); 1p. 50-56. 


\section{The 2004 HMDA Data on Manufactured Housing}

The 2004 HMDA data indicate that, on the basis of applications that lenders received after January 1 , 2004 , nearly 4,400 lenders extended more than 242,000 manufactured-home loans. ${ }^{33}$ About 57 percent of these loans were for home purchases; most of the rest were for refinancing an earlier loan (data derived from table 5). Commercial banks, the largest source of loans on manufactured homes, extended 46 percent of the total number; mortgage companies extended 44 percent.

The data indicate further that manufactured home lending is a relatively concentrated business. The ten lenders that extended the largest number of manufactured home loans in 2004 accounted for onethird of all such loans that year, and the top twenty such lenders accounted for 42 percent (data not shown in tables). Likewise, 60 percent of the lenders that extended manufactured-home loans in 2004 extended ten or fewer such loans. The 2004 data indicate that thirty-five lenders could reasonably be considered to have specialized in manufactured home lending that year (see box "The HUD List of Specialists in Manufactured Home Lending and the 2004 HMDA Data").

For a number of the largest lenders that extended manufactured home loans (measured by the number of such loans), that business segment was only a very small portion of their lending activity, according to the 2004 data. In fact, among the twenty-five firms that extended the largest number of manufacturedhome loans, only three could be characterized as focused primarily on that business segment. For virtually all the rest, manufactured home lending amounted to 5 percent or less of their total lending activity.

Of those obtaining loans to purchase manufactured homes, 41 percent were of lower income, whereas of those borrowing to purchase site-built homes, about

33. As noled, the transition rules regarding the reporting of data pose difficulties for evaluating the $2004 \mathrm{IIMDA}$ data for manufactured homes, Consequently, applications governed by the transition rules are excluded from Latbles 5 and 6 . Despite the reporting exceptions crated by the rules, some lenders chose to mport intomation on manufactured-homs status for applications submittat bofort January 1, 2004. However, it is not clear whelher these lenclers idenlilied all, or omly some, of the pre-2004 applications for loans on manufactured homes, and so we cxelude these additional data from the antalysis.

The 2004 dala inclucte information on applications or loans related to manufacturat homs from an additional 400 or so lenders-about 4,800 in all-which indicates that some institutions chose to identity manufactured homes on applications laken during the transition period (before Tanuary 1, 2004).

\section{The HUD List of Specialists in Manufactured-Home Lending and the 2004 HMDA Data}

Before 2004, HMDA reporters were not required to identify which of their applications and loans involved manufactured homes, and identifying all of the lenders offering such credit was impossible. For 2003, HUD's list of manufactured-homc loan specialists who are also HMDA reporters identified 19 such lenders. Only 13 of the 19 lenders that reported 2003 HMDA data provided 2004 HMDA data under the same name and identification number. These 13 lenders accounted for 15 percent of all the manufactured-home loans reported in the 2004 data. Among the 6 manufactured-home lenders on the 2003 HUD list that did not report in 2004 under the same name or identification number, 2 reported under different names and identification numbers. These 2 lenders reported information on only about 950 loans related to manufactured homes (about 0.4 percent of the total). Of the 15 manufactured-home loan specialists on the HUD list that reported data for 2004 , only 11 were in fact primarily involved in extending loans on manufactured homes.

For 35 lenders that supplied 2004 data (including the 11 on the 2003 HUD list), lending for manufactured homes constituted at least 80 percent of their reported lending activity, and so they may reasonably warrant consideration as specialists in manutachued-home lending. Among the rest of the approximately 4,400 reporting lenders that had extended at least one manufacturedhoms loan in 2004, about 500 indicated that the proportion of their originations related to manufactured homes was at least 20 percent but less than 80 percent, and the remaining 3,900 indicated that the proportion was less than 20 percent.

24 percent had lower incomes (table 6) ${ }^{34}$ On average, minority borrowers have lower incomes than do non-Hispanic white borrowers, but only about 18 percent of manufactured home purchasers were members of a racial or ethnic minority group, whereas about 30 percent of purchasers of site-built homes were minorities (data derived from table 6)..$^{35}$

34. The income category of a purchaser is relative to the median family income of the area (MSA or statewide non-MSA) in which the property being purchased is localect, and the income calegory of a census tract is the median family income of the tract relative to that of the aroa (MSA or statiwide non-MSA) in which the tract is located: "T.ow" is less than 50 percent of the median: "moderate" is 50 percent lo 79) percent (in this articte, "lower income" encompasses the low and moderate catchoriss): "midde" is 80 percent to 119 perent; and "higher" is 120 prest or mors.

35. For loams with two or more applicanls. HMT)A-covered lencters report data on only Lwo. Tncome for Lwo applicanls is reported joinlly. 
5. Distribution of loans on manufactured homes, by type of loan and type of home lender, 2004

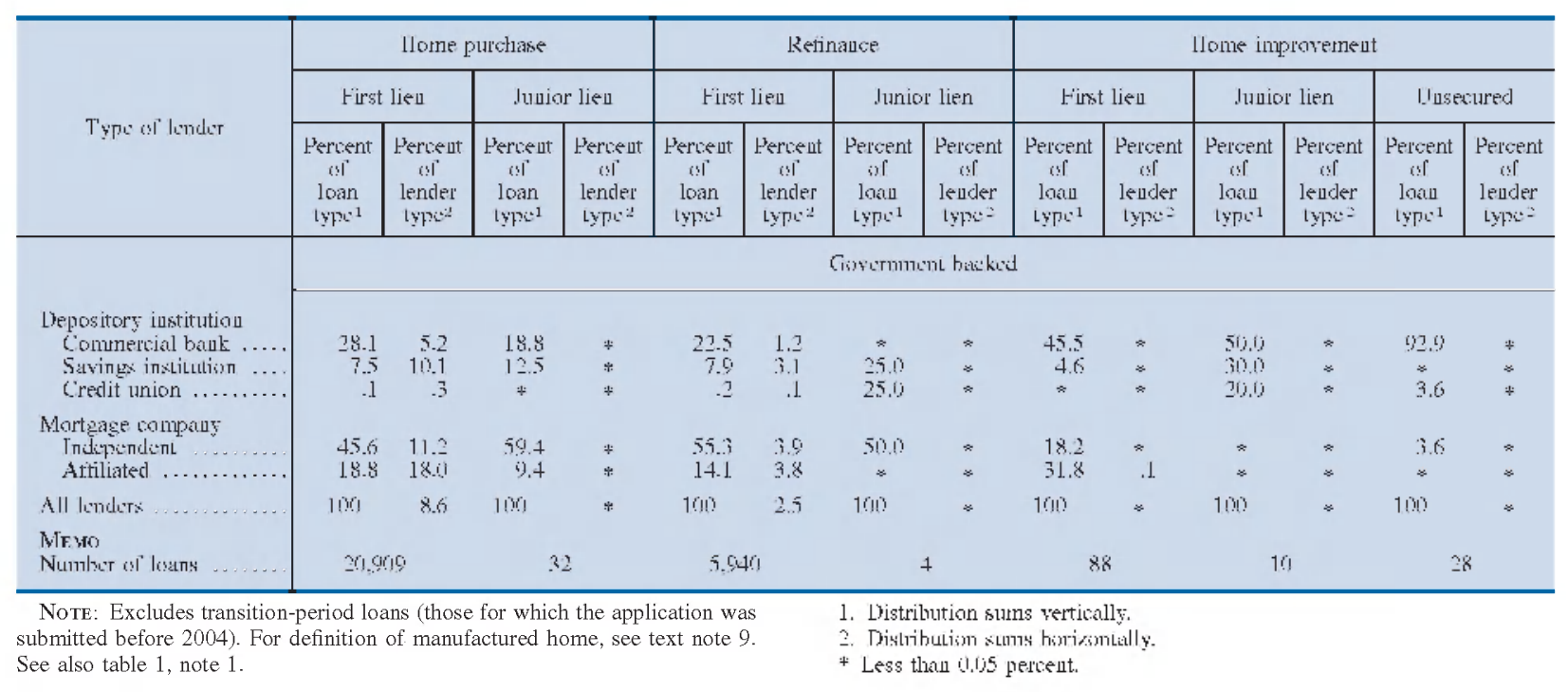

\section{Requests for Pre-Approval}

The 2004 data for the first time include information on certain types of requests for pre-approval of homepurchase loans. Since pre-approval programs pertain only to requests for loans to purchase a home, the HMDA data do not include pre-approval information for applications involving a refinancing or homeimprovement loan. Although all requests for preapproval that are turned down must be reported, lenders have the option of reporting requests for pre-approval that were approved but not acted on by the consumer. Because many lenders apparently chose not to report any optionally reportable requests for pre-approval, the new data do not account completely for pre-approval activity. Nonetheless, the new reporting scheme is sufficiently comprehensive to identify which individuals were denied at the preapproval stage and which successful borrowers initiated the borrowing process through a pre-approval program.

Nearly half of all lenders reported some preapproval activity, although the volume of such activ-

Although, as of 2004 applicants may choose more than one race as well as one of two thnicitics. applications are placed for the purposes of table 6 and tables 9 through 13 under only one catrogry for race and ethricity, gemerally according to the race and elhnicity of the person listed lirst on the applicaliom. However, under race, the alpplicattion is designatod as joint it one applicant reported the single disignation of white ant the other reported one or more minority races. If the application is not joint but more than one race is reportect, the following designations are mads: It at last two minority races are reported, the application is designated as two or more minority races; if the lirst person listed on an application reports two races, and one is white, the application is calegoriyed uncter the mincrily race. ily varied greatly across lenders. ${ }^{36}$ The five lenders that reported the greatest number of requests for pre-approval accounted for one-third of all such requests. Some differences in the propensity to offer pre-approval programs were found by type of institution; more than half of the reporting credit unions, savings institutions, and mortgage companies reported requests for pre-approval, but only about one-third of the commercial banks reported such information.

Although requests for pre-approval are far fewer in number than home-purchase loan applications that do not begin through this channel, they are not rare events. The 2004 data include information about 1 million requests for pre-approval for first-lien loans to buy homes and about 100,000 for junior liens. Of those institutions with pre-approval programs, 82 percent did not report any pre-approval requests that were approved but not acted on by the consumer, an indication that these institutions chose not to report all their requests for pre-approval.

\section{DENIALS AND PRICING IN THE 2004 DATA}

A central element of the 1989 revisions to HMDA was the collection of loan-level data on the disposition of home-loan applications, and the 2002 revisions to Regulation C expanded this concept to include loan-level information on pricing. This

36. Pri-approvals wors subjuct to the transition ruls:s; constquently, these numbers and the others in this section exclude applicaLions submilted before 2004 . 


\section{5.-Continued}

\begin{tabular}{|c|c|c|c|c|c|c|c|c|c|c|c|c|c|c|c|}
\hline \multirow{3}{*}{ Туре of lendet } & \multicolumn{4}{|c|}{ Home purchase } & \multicolumn{4}{|c|}{ Retiuance } & \multicolumn{6}{|c|}{ Home improvement } & \multirow{4}{*}{$\begin{array}{l}\text { Mrano } \\
\text { Number } \\
\text { oi } \\
\text { loaus }\end{array}$} \\
\hline & \multicolumn{2}{|c|}{ First lien } & \multicolumn{2}{|c|}{ Iunior lien } & \multicolumn{2}{|c|}{ First lien } & \multicolumn{2}{|c|}{ Iunior lien } & \multicolumn{2}{|c|}{ First lien } & \multicolumn{2}{|c|}{ Junior lien } & \multicolumn{2}{|c|}{ IIusecured } & \\
\hline & $\begin{array}{c}\text { Perceut } \\
\text { as } \\
\text { loan } \\
\text { lype }\end{array}$ & $\begin{array}{c}\text { Percent } \\
\text { sil } \\
\text { lender } \\
\text { lyp:2 }\end{array}$ & $\begin{array}{c}\text { Percent } \\
\text { oi } \\
\text { loan } \\
\text { typo: }\end{array}$ & $\begin{array}{l}\text { Percent } \\
\text { of } \\
\text { lender } \\
\text { Lypo: }\end{array}$ & $\begin{array}{c}\text { Percent } \\
\text { of } \\
\text { loaul } \\
\text { type }\end{array}$ & $\begin{array}{l}\text { Percent } \\
\text { of } \\
\text { leuder } \\
\text { typiz: }\end{array}$ & $\begin{array}{c}\text { Percent } \\
\text { oi } \\
\text { oan } \\
\text { typo. }\end{array}$ & $\begin{array}{l}\text { Percent } \\
\text { ail } \\
\text { lender } \\
\text { Lypi: }\end{array}$ & $\begin{array}{c}\text { Percent } \\
\text { xil } \\
\text { loan } \\
\text { typo-1 }\end{array}$ & $\begin{array}{l}\text { Percent } \\
\text { of } \\
\text { lender } \\
\text { Lypo: }\end{array}$ & $\begin{array}{c}\text { Percent } \\
\text { of } \\
\text { loaul } \\
\text { type }\end{array}$ & $\begin{array}{c}\text { Percent } \\
\text { is } \\
\text { leuder } \\
\text { lypo: }\end{array}$ & $\begin{array}{c}\text { Percent } \\
\text { if } \\
\text { loal } \\
\text { Lypi }\end{array}$ & $\begin{array}{l}\text { Percent } \\
\text { of } \\
\text { leuder } \\
\text { lypo:2 }\end{array}$ & \\
\hline & \multicolumn{14}{|c|}{ 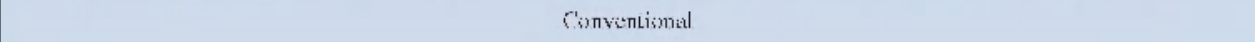 } & \\
\hline $\begin{array}{l}\text { Depository iustitution } \\
\text { Commercial bauk ... } \\
\text { Savings institution ... } \\
\text { Credit union ........ }\end{array}$ & $\begin{array}{r}48.4 \\
6.5 \\
3.0\end{array}$ & $\begin{array}{l}49.1 \\
50.9 \\
446\end{array}$ & $\begin{array}{r}24.2 \\
3.4 \\
17.8\end{array}$ & $\begin{array}{r}.6 \\
6.2 \\
6.2\end{array}$ & $\begin{aligned} 45.8 \\
5.8 \\
3.5\end{aligned}$ & $\begin{array}{l}31.6 \\
20.0 \\
35.9\end{array}$ & $\begin{array}{r}41.9 \\
6.2 \\
7.6\end{array}$ & $\begin{array}{l}1.1 \\
1.2 \\
2.7\end{array}$ & $\begin{array}{l}61.6 \\
5.5 \\
3.5\end{array}$ & $\begin{array}{l}4.8 \\
3.1 \\
4.0\end{array}$ & $\begin{array}{r}63.9 \\
3.9 \\
6.2\end{array}$ & $\begin{array}{l}2.6 \\
1.2 \\
3.8\end{array}$ & $\begin{array}{r}8 i 9.7 \\
2.5 \\
4.5\end{array}$ & $\begin{array}{r}3.7 \\
.8 \\
2.5\end{array}$ & $\begin{array}{r}1.2 .385 \\
1.5,391 \\
7.632\end{array}$ \\
\hline 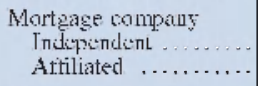 & $\begin{array}{r}3.5 .5 \\
5.8\end{array}$ & $\begin{array}{l}48.2 \\
30.2\end{array}$ & $\begin{array}{r}51.2 \\
3.4\end{array}$ & $\begin{array}{r}1.6 \\
.4\end{array}$ & $\begin{array}{l}33.4 \\
11.5\end{array}$ & $\begin{array}{l}30.5 \\
40.9\end{array}$ & $\begin{array}{r}36.6 \\
8.3\end{array}$ & $\begin{array}{l}1.3 \\
1.1\end{array}$ & $\begin{aligned} 21.2 \\
8.2\end{aligned}$ & $\begin{array}{l}2.2 \\
3.3\end{array}$ & $\begin{array}{r}190 \\
7.01\end{array}$ & $\begin{array}{l}1.9 \\
1.5\end{array}$ & $\frac{.3}{3.5}$ & $* 8$ & $\begin{array}{l}84,940 \\
21.849\end{array}$ \\
\hline All lenders: & 100 & 47.1 & 100 & 1.1 & 100 & 3201 & 1010 & 1.2 & 100 & 3.6 & 100 & 1.9 & 100 & 1.9 & 242.197 \\
\hline $\begin{array}{l}\text { Mrowo } \\
\text { Numlye of lesans }\end{array}$ & 1140 & 121 & $2,6.5$ & & 77,5 & & 2.00 & & 8.73 & & 4,63 & & 4,60 & & 242.197 \\
\hline
\end{tabular}

section summarizes the aggregate outcomes on both points. Because the transition rules regarding the reporting of data create problems for assessing some of the 2004 data regarding loan pricing, as they do for manufactured homes and pre-approvals, the analysis that follows excludes "transition" applicationsthose submitted before January 1, 2004 (data on these applications are shown as memo items in tables 7 and 8). Otherwise, information is given on all applications reported under HMDA. For presentation, applications were grouped into twenty-five product categories based on loan and property type, purpose of the loan, and lien and owner-occupancy status. ${ }^{37}$ For each product category, information is provided on the number of total and pre-approval applications, application denials, originated loans, loans with prices above the thresholds, loans covered by HOEPA, and the mean and median spreads for loans priced above certain thresholds.

\section{Denial Rates}

For the past fifteen years or so, the HMDA data have been the primary source of publicly available data on the disposition of applications for home loans. The expanded HMDA data for 2004 provide new opportunities to assess patterns in the disposition of applications at different stages of the lending process and across product lines and applicant groups.

37. Applications in which the lender reported that the race, sthnicity. and ssex of the applicant or co-applicant were "not applicable" were assumed to have beell made by businesses (including trusts) rather than by indivicluals.
Denial Rates across Products

The incidence of denials differs substantially across loan products. Lenders deny only about 15 percent of the applications for home-purchase loans on oneto four-family site-built homes, whether the loans are secured as a first lien or a junior lien and whether they are conventional or government backed (table 7). In contrast, about 30 percent to 36 percent of refinancings and home-improvement loan applications involving first liens are denied, as are about 50 percent of the applications for manufactured homes. The main exception to this pattern is applications for government-backed first-lien loans for refinancings, which have a denial rate similar to that of home-purchase loans.

Of particular importance are the disposition patterns for applications for manufactured homes. As noted, past HMDA data did not distinguish applications for manufactured homes from those for site-built properties. Analysis of the HUD list of manufactured-home loan specialists suggested that such lenders had very high denial rates, and that for lenders offering both manufactured-home loans and other home loans a distorted picture of their propensity to deny credit could easily be drawn. The 2004 data confirm the importance of distinguishing applications for manufactured homes from those for site-built properties. For example, adding the applications for conventional home-purchase first liens for manufactured homes to those for one- to four-family site-built homes would increase the number of total lender actions on applications only 7 percent but the number of denials more than 25 percent. The denial rate for the category "conventional 
6. Distribution of home-purchase loans for one- to four-family owner-occupied homes, by characteristic of borrower and of census tract and by type of home, 2004

\begin{tabular}{|c|c|c|c|c|c|c|c|}
\hline \multirow{2}{*}{$\begin{array}{l}\text { Characteristis: } \\
\text { and status: }\end{array}$} & \multicolumn{2}{|c|}{ Sits built. } & \multicolumn{2}{|c|}{ Mimufixitured } & \multicolumn{2}{|c|}{ 'Tistal } & \multirow{2}{*}{$\begin{array}{l}\text { MLino } \\
\text { Number }\end{array}$} \\
\hline & $\begin{array}{c}\text { Purcent of } \\
\text { characteristio: }^{1}\end{array}$ & $\begin{array}{l}\text { Percent of } \\
\text { status: }\end{array}$ & $\begin{array}{c}\text { Pacent of } \\
\text { charasteristio } 1\end{array}$ & $\begin{array}{l}\text { Percent iol } \\
\text { status: } 2\end{array}$ & $\begin{array}{c}\text { Present of } \\
\text { characteristic } 1\end{array}$ & $\begin{array}{l}\text { Percent of } \\
\text { statuss }\end{array}$ & \\
\hline \multicolumn{8}{|l|}{ T\}ORROWFR } \\
\hline Incone fatio tperent of arta nedian? & & & & & & & \\
\hline 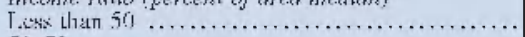 & 4.7 & 93.3 & 12.2 & 6.8 & 4.9 & 100 & 205,771 \\
\hline $5079, \ldots \ldots \ldots+\cdots \cdots$ & 18.9 & 958 & 29.1 & 4.2 & 10.2 & 100 & 798,6012 \\
\hline 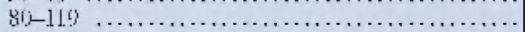 & $2 \% .4$ & 97.2 & 30.1 & 2.8 & 295 & 100 & $1.327,(19) 1$ \\
\hline 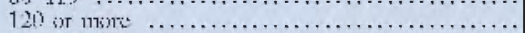 & 46.9 & 98.3 & 28.7 & 1.7 & 46.4 & 100 & 1.933 .772 \\
\hline 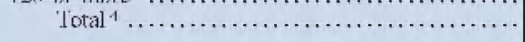 & liiij & 97.3 & Litii & 2.8 & liiij & $10 j$ & $4.165,236$ \\
\hline \multicolumn{8}{|l|}{ Race } \\
\hline American Tndian \& Alaska Talive ... & 8 & 96.1 & 1.2 & 39 & 8 & 100 & 36,650 \\
\hline 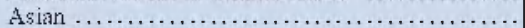 & 4.9 & 99.7 & .5 & .3 & 4.7 & $100 j$ & 2061,316 \\
\hline Black or A Afican American & 7.1 & 97.9 & 5.4 & 2.1 & 70 & 100 & 305.42 \\
\hline Native llawaiiau or other Pavitic Islauder ......... & 5 & $8 \times 3$ & .3 & 1.7 & 5 & 100 & 33,246 \\
\hline White ..................................... & 74.9 & 96.9 & 84.4 & 3.1 & 75.2 & $100 j$ & $3.7801,354$ \\
\hline Tư es moris minsily races & .1 & 97.9 & .1 & 2.1 & 1 & 100 & 3,282 \\
\hline 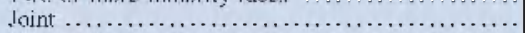 & 1.4 & 080 & $1 . i$ & $2 . i$ & 1.4 & $10 i j$ & $5 i) .524$ \\
\hline Missing ${ }^{5}$................................. & 10.4 & 98.1 & 7.2 & 1.9 & 103 & 100 & 447.970 \\
\hline lotal $\ldots \ldots \ldots \ldots \ldots \ldots \ldots \ldots \ldots \ldots \ldots \ldots \ldots \ldots \ldots$ & $1010 j$ & 97.3 & Lilii) & 2.8 & liiij & $100 j$ & $4,363,174$ \\
\hline \multicolumn{8}{|l|}{ Ethricity } \\
\hline 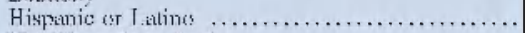 & 11.2 & 98.2 & 7.4 & 1.8 & 11.1 & 100 & $48,2,253$ \\
\hline 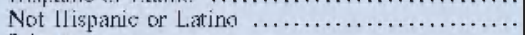 & 76.4 & 97.1 & 82.1 & 2.9 & 36.6 & $10 j$ & $3.341,970$ \\
\hline 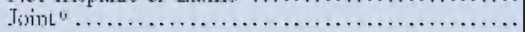 & $1 . .1$ & 970 & 1.9 & 2.1 & 1.3 & 100 & 5.5914 \\
\hline 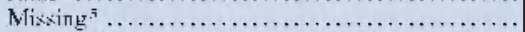 & 11.1 & 97.7 & 9.5 & 2.4 & 11.1 & 100 & 4820128 \\
\hline 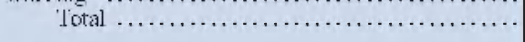 & $10 i i j$ & 97.3 & Lilii & 2.8 & liiij & $10 j$ & $4,363,174$ \\
\hline \multicolumn{8}{|l|}{ Minority statses } \\
\hline 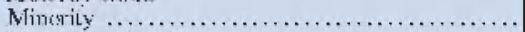 & 260 & 98.3 & 15.9 & 1.7 & 2.5 .7 & 100 & $1,120,646$ \\
\hline Non-llispanit white $\ldots \ldots \ldots \ldots \ldots \ldots \ldots \ldots$ & 612.6 & 96.8 & 73.7 & 3.2 & 612.9 & $10 j$ & $2.745,937$ \\
\hline Mixsing ${ }^{=}$. & 11.4 & 97.5 & $10.3^{2}$ & 2.5 & 11.4 & 100 & 466.591 \\
\hline 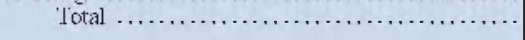 & liiij & 97.3 & Litii & 2.8 & $100 j$ & $10 i j$ & $4,363,174$ \\
\hline \multicolumn{8}{|l|}{ CFaste Truet of Proptaty } \\
\hline Incone ratio iperent of area nedian! & & & & & & & \\
\hline 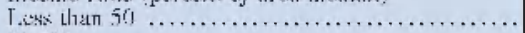 & 1.6 & 99.1 & .5 & 9 & 1.5 & 100 & 65.777 \\
\hline 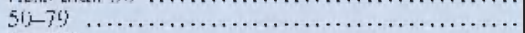 & 13.2 & 96.7 & 16.8 & 3.4 & 13.3 & $100 j$ & 575,0170 \\
\hline 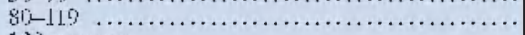 & 49.3 & 96.3 & 71.4 & 3.8 & 49.8 & 100 & 2.149 .842 \\
\hline 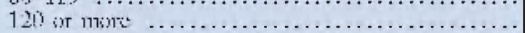 & 360 & 99.1 & 11.4 & 9 & 353 & 100 & $1.524,643$ \\
\hline 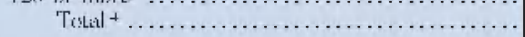 & 1010 & 97.3 & 100 & 2.7 & 1019 & 100 & $4,315,322$ \\
\hline \multirow{2}{*}{\multicolumn{8}{|c|}{ Rarial or ethatic empmonition }} \\
\hline & & & & & & & \\
\hline T...ss Lhan 10 ......................... & 32.5 & 96.5 & 43.4 & 3.5 & 32.8 & 100 & $1,417,2011$ \\
\hline 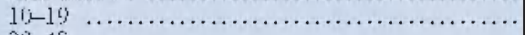 & 23.9 & 97.6 & 21.1 & 2.5 & 23.6 & $10 j j$ & $988,166_{1}$ \\
\hline 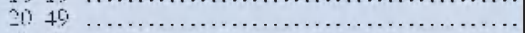 & 27.7 & 97.5 & 25.7 & 2.5 & 27.7 & 100 & 1.193 .394 \\
\hline 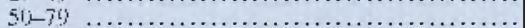 & 10]$. & 98.0 & 7.6 & $2 . i)$ & 10.7 & $10 i j$ & 438,175 \\
\hline 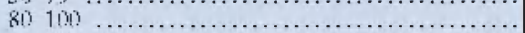 & 66 & 99.1 & 2.2 & 09 & 6.5 & 100 & 279.509 \\
\hline 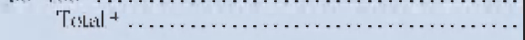 & 1010 & 97.3 & 100 & 2.7 & 100 & 100 & $4,316,341$ \\
\hline \multicolumn{8}{|l|}{ S.oretiont } \\
\hline 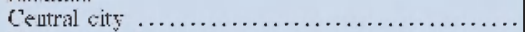 & 38.5 & 98.8 & 17.1 & 1.2 & 38.0 & $100)$ & 1.642 .184 \\
\hline Nemesentral cily ....................................... & 52.7 & 97.6 & 47.2 & 2.4 & 52.5 & 100 & 2.272 .738 \\
\hline Rural or ouly state known $\ldots \ldots \ldots \ldots \ldots \ldots \ldots$ & 8.8 & 90.05 & 35.6 & $10 i i$ & 9.5 & $10 j i$ & $41.1,823$ \\
\hline 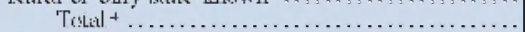 & 1019 & 97.3 & 100 & 2.7 & 1010 & 100 & $4,326.744$ \\
\hline
\end{tabular}

Note: Excludes transition-period loans (those for which the application was submitted before 2004). For definition of income categories for borrower and census tract, see text note 34 . Census tract is for the property securing the loan. Categories for race and ethnicity reflect the revised standards established in 1997 by the Office of Management and Budget (OMB); for details, see text discussion. The term minority means Hispanic or Latino ethnicity or any race other than white. Census-tract data reflect the 2000 decennial census; they also reflect definitions for metropolitan statistical areas established by the OMB in June 2003 and used in HMDA for the first time in the 2004 data (see note 2 in main-text box "Distribution of HMDA Data and Pre-2004 Requirements of Regulation $\mathrm{C}^{\prime \prime}$ ).

home-purchase first liens" would increase from 14.9 percent to 17 percent (data derived from table). Although this change might not appear large in the aggregate, for some lenders it could create a major distortion.

1. Distribution sums vertically.

2. Distrilution sums horizontally.

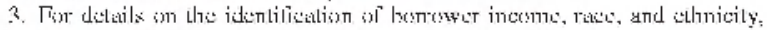
see text note 35 .

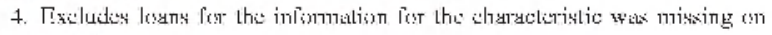
the sypplicialism.

5. Intormation for the characteristic was missing on the application.

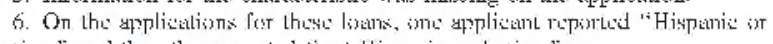
Latino," and the other reported "not llispanic or Latino."

Denials of Requests for Pre-Approval

Denial rates for applications that begin with requests for pre-approval can be computed in different ways, especially since lenders need not report approved 
requests for pre-approval not acted on by the borrowers. One way to assess the disposition of applications received through the pre-approval process is to compute denial rates for requests for pre-approval separately from the denial rates for subsequent applications related to a specific property. Another way of assessing denial rates is to combine the two stages (pre-approval requests and subsequent applications for a specific property) and to treat a denial at either stage as a denial.

The denial rates for pre-approval requests (column 3 of table 8 ) are similar to the denial rates for all applications for home loans on specific properties (column 4 of table 7). Not surprisingly, the denial rates on applications for a specific property that began as requests for pre-approval (derived from columns 5 and 6 of table 8) are lower than the denial rates on pre-approval requests and on applications for a specific property that did not come through the pre-approval process. But although they are relatively low, the denial rates for preapproved borrowers are not zero: More than 8 percent of pre-approved applicants for conventional first-lien home-purchase loans are turned down when they apply for a loan on a specific property.

If we view requests for pre-approval and applications for loans to purchase a specific property as elements of a single process, the data suggest that the overall denial rates for applicants for home loans on specific properties who came through the preapproval process are about the same as for applicants who did not first request a pre-approval. Seventeen percent of the applicants for conventional first-lien home-purchase loans who came through the preapproval process were denied versus 15 percent of those who did not first request a pre-approval (data derived from tables 7 and 8 ).

However, origination rates for the two groups were very different. Only 49 percent of the applicants for conventional first-lien home-purchase loans who began the process with a request for a pre-approval ended up with a loan, compared with 67 percent of other applicants. This difference appears to stem not from lender actions but from markedly different rates of withdrawal from the process by applicants. Thirty-four percent of applications for conventional first-lien home-purchase loans that started at the preapproval stage are withdrawn by the applicant at some point (or not acted on by the lender). The withdrawal rate for other applications is much lower (19 percent).

\section{Reported Reasons for Denial}

The HMDA data include information from lenders on why they turned down an application. Lenders generally provide the information voluntarily; however, two federal bank supervisory agencies, the Office of Thrift Supervision and the Office of the Comptroller of the Currency, require the institutions they supervise to report this information. ${ }^{38}$

Institutions are allowed to cite up to three reasons (from a list of nine) that an application was turned down. Overall, one or more reasons for denial were provided for about 81 percent of the denials across all loan products and for about 75 percent of the denials for home-purchase loans (data not shown in tables). Poor or no credit history was the most frequently cited reason for denying applications: Credit-related issues were cited in about 26 percent of the denials of applications for conventional first-lien loans to purchase one- to four-family site-built homes and in about 52 percent of the denials of applications for such loans to purchase manufactured homes. Other reasons often cited for credit denials involved excessive debt-to-income ratios, issues related to collateral, and unverifiable or incomplete information on applications; a catch-all category in the HMDA data labeled "other" was also frequently cited.

\section{Loan Pricing}

Because of the transition rules, some unknown proportion of higher-priced loans was reported in the same way as loans that did not meet the threshold requirements. ${ }^{39}$ The inability to identify higher-priced loans that were originated in 2004 but had application dates preceding that year means that users of the data need to take special account of these applications when conducting analyses.

\section{Reasons for Loan-Price Variation}

The HMDA data on loans in the higher-priced segment of the home-loan market do not include much

\footnotetext{
38. Reasoms for denial are not provided for requests for preapprovals that are deniect.

39. Analysis of the data is further complicated bccausc loans not subject to the Fethral Reserve's Regulation 7.that is, husiness loans-are reported with the same cocte as loams with spreads below the threshold. Some, perhaps most. of these loans are identifiable, however. txcause. as explained in text not 37, an application can bo identified as being from at lrust or other organization rather than from at person.
} 
7. Disposition of applications for home loans, and origination and pricing of loans, by type of home and type of loan, 2004

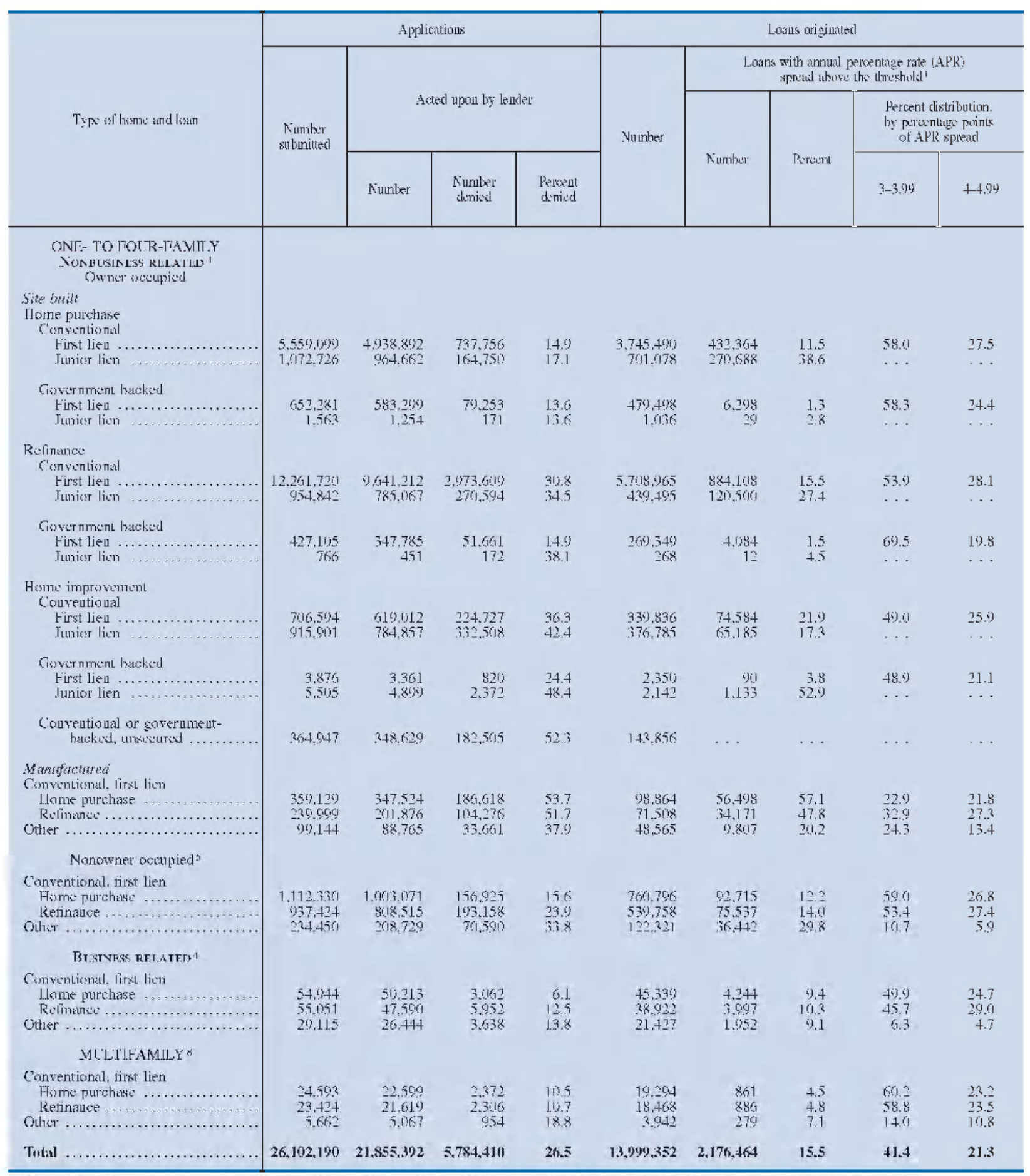

NotE: Excludes transition-period applications (those submitted before 2004) and transition-period loans (those for which the application was submitted before 2004).

1. APR spread is the ditterence between the APR on the loan and the yield on a comparalle-maturity l'reasury security. 'The threshold for tirst-lien loans is

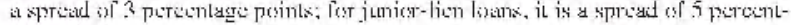
age points.

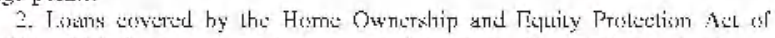

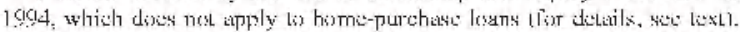

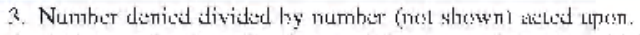

4. Business-related applications and loans are those for which the lender

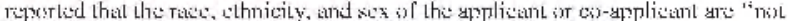
applicable"; all other applications and loans are noubusiness related.

5. Includes applications and loans tor which occupancy status was missing.

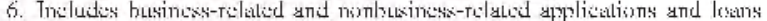
for owner-occupied and unnowner-ocupied properties.

. . Tis applictable 
7.-Continued

\begin{tabular}{|c|c|c|c|c|c|c|c|c|c|c|c|}
\hline \multicolumn{6}{|c|}{ Loans originated } & \multicolumn{5}{|c|}{ 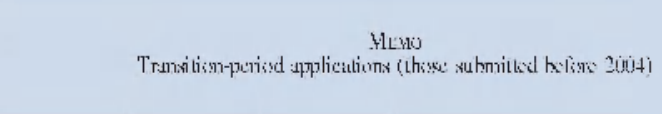 } & \multirow{3}{*}{ 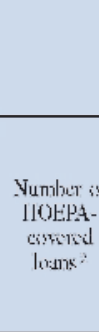 } \\
\hline \multicolumn{3}{|c|}{ 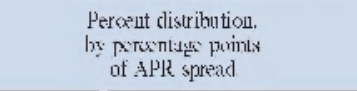 } & \multicolumn{2}{|c|}{$\begin{array}{l}\text { APR spread } \\
\text { (percentuge psinls) }\end{array}$} & \multirow{2}{*}{ 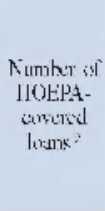 } & \multirow{2}{*}{$\begin{array}{l}\text { Ywunher } \\
\text { xulbnilued }\end{array}$} & \multirow{2}{*}{$\begin{array}{l}\text { Younher } \\
\text { derived }\end{array}$} & \multirow{2}{*}{$\begin{array}{l}\text { Perkent } \\
\text { dinieds }\end{array}$} & \multicolumn{2}{|c|}{ 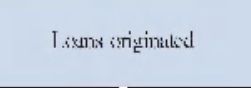 } & \\
\hline $5-6,90$ & $7-8.99$ & 9) or mole & Mean & Hedian & & & & & Nunler & $\begin{array}{l}\text { Pirsunt with } \\
\text { APlk spread } \\
\text { uthurs } \\
\text { theshold }\end{array}$ & \\
\hline$\frac{13.2}{76.2}$ & $\frac{1.2}{21.7}$ & .2 .2 & $\begin{array}{l}4.1 \\
6.4\end{array}$ & $\frac{3.8}{6.2}$ & $\cdots$ & $\begin{array}{r}490,846 \\
47,351\end{array}$ & $\begin{array}{r}41,115 \\
5,2,30\end{array}$ & $\begin{array}{r}9.9 \\
1.34\end{array}$ & $\begin{array}{r}303.881 \\
26.475\end{array}$ & $\begin{array}{r}5.1 \\
2.1\end{array}$ & $\cdots$ \\
\hline $\begin{array}{l}12.7 \\
600\end{array}$ & $\begin{array}{r}4.3 \\
17.2\end{array}$ & 13.8 & $\begin{array}{l}4.2 \\
7.1\end{array}$ & $\frac{3.9}{6.0}$ & $\cdots$ & $\begin{array}{r}85.806 \\
226\end{array}$ & 8.172 & $\begin{array}{r}11.5 \\
9.8\end{array}$ & $\begin{array}{r}56,693 \\
1.34\end{array}$ & 2.7 & $\cdots$ \\
\hline $\begin{array}{l}15.7 \\
58.3\end{array}$ & 28.3 & 12.29 & $\begin{array}{l}4.2 \\
7.3\end{array}$ & $\frac{3.9}{6.7}$ & $\begin{array}{l}7.249 \\
3.987\end{array}$ & $\begin{array}{r}813,761 \\
36,965\end{array}$ & $\begin{array}{r}106,316 \\
6,184\end{array}$ & $\begin{array}{l}18.5 \\
21.6\end{array}$ & $\begin{array}{r}333.550 \\
16.470\end{array}$ & $\begin{array}{l}101.7 \\
23.7\end{array}$ & $\begin{array}{l}322 \\
177\end{array}$ \\
\hline $\begin{array}{l}9.4 \\
58.3\end{array}$ & $\begin{array}{r}1.0 \\
41.7\end{array}$ & $a^{.3}$ & $\begin{array}{l}3.9 \\
6.7\end{array}$ & $\frac{3.6}{6.6}$ & $\begin{array}{r}496 \\
2 \\
2\end{array}$ & $\begin{array}{r}49,849 \\
63\end{array}$ & $\begin{array}{r}6,0108 \\
6\end{array}$ & $\begin{array}{l}1.59 \\
21.4\end{array}$ & $\begin{array}{r}23,485 \\
19\end{array}$ & $0^{.8}$ & $L_{0}$ \\
\hline $\begin{array}{l}19.4 \\
41.5\end{array}$ & $\begin{array}{r}4.5 \\
27.9\end{array}$ & $\begin{array}{r}1.1 \\
30.7\end{array}$ & $\begin{array}{l}4.4 \\
8.0\end{array}$ & $\frac{4.0}{7.6}$ & $\begin{array}{l}1,665 \\
5,046\end{array}$ & $\begin{array}{l}13,773 \\
21,962\end{array}$ & $\begin{array}{l}1,733 \\
4,342\end{array}$ & $\begin{array}{l}14,6 \\
24.0\end{array}$ & $\begin{array}{r}7.912 \\
10,646\end{array}$ & $\begin{array}{l}14.6 \\
13.6\end{array}$ & $\begin{array}{r}63 \\
158\end{array}$ \\
\hline $\begin{array}{l}21.1 \\
23.1\end{array}$ & $\begin{array}{r}7.8 \\
20.3\end{array}$ & $\begin{array}{r}1.1 \\
47.6\end{array}$ & $\begin{array}{l}4.7 \\
9.2\end{array}$ & $\begin{array}{l}4.05 \\
8.9\end{array}$ & $\begin{array}{r}4 \\
1,0013\end{array}$ & $\begin{array}{l}391 \\
373\end{array}$ & $\begin{array}{l}74 \\
67\end{array}$ & $\frac{75,0}{301.6}$ & $\begin{array}{r}189 \\
88\end{array}$ & $\begin{array}{r}3.7 \\
43.2\end{array}$ & 17 \\
\hline$\cdots$ & $\cdots$ & $\cdots$ & $\ldots$ & $\ldots$ & $\cdots$ & 4,881 & 1,209 & 27.1 & 2,132 & $\ldots$ & $\ldots$ \\
\hline $\begin{array}{l}37.4 \\
2 \times 9 \\
30.5\end{array}$ & $\begin{array}{r}16.8 \\
8.2 \\
16.4\end{array}$ & $\begin{array}{r}6.01 \\
2.8 \\
1.5 .4\end{array}$ & $\begin{array}{l}5.7 \\
50 \\
6.4\end{array}$ & $\begin{array}{l}5.7 \\
4.6 \\
5.5\end{array}$ & $\begin{array}{r}1,830 \\
9040\end{array}$ & $\begin{array}{r}9,595 \\
12,252 \\
6,679\end{array}$ & $\begin{array}{r}1,177 \\
2.370 \\
722\end{array}$ & $\begin{array}{l}13.8 \\
2.50 \\
12.5\end{array}$ & $\begin{array}{l}5.013 \\
4.5001 \\
4.3018\end{array}$ & $\begin{array}{r}72.2 \\
21.2 \\
4.9\end{array}$ & ${ }^{41}$ \\
\hline $\begin{array}{l}11.6 \\
16.4 \\
50.9\end{array}$ & $\begin{array}{r}1.8 \\
2.4 \\
2.5\end{array}$ & $\begin{array}{r}.8 \\
.5 \\
6.8\end{array}$ & $\begin{array}{l}4.1 \\
4.2 \\
6.4\end{array}$ & $\begin{array}{l}3.8 \\
3.9 \\
6.1\end{array}$ & $\begin{array}{l}612 \\
218\end{array}$ & $\begin{array}{r}84.652 \\
82,569 \\
8,684\end{array}$ & $\begin{array}{r}7,864 \\
11,682 \\
1,120\end{array}$ & $\begin{array}{l}10.8 \\
17.3 \\
15.7\end{array}$ & $\begin{array}{r}53,019 \\
43.145 \\
4,730\end{array}$ & $\begin{array}{r}7.8 \\
9.1 \\
24.9\end{array}$ & 34 \\
\hline $\begin{array}{l}\frac{36.7}{21.6} \\
64.3\end{array}$ & $\begin{array}{r}3.5 \\
3.2 \\
30.9\end{array}$ & $\begin{array}{r}1.2 \\
.5 \\
3.8\end{array}$ & $\begin{array}{l}4.4 \\
4.4 \\
6.2\end{array}$ & $\begin{array}{l}4.1 j \\
4.1 \\
6.1\end{array}$ & $\underset{104}{i j}$ & $\begin{array}{r}87,4725 \\
117,852 \\
42,414\end{array}$ & $\begin{array}{r}11.530 \\
25.941 \\
7.973\end{array}$ & $\begin{array}{l}14.9 \\
25.4 \\
22.6\end{array}$ & $\begin{array}{l}51 j, 885 \\
54.026 \\
21.444\end{array}$ & $\begin{array}{r}5.7 \\
10.5 \\
9.8\end{array}$ & $\begin{array}{r}36 \\
1.21\end{array}$ \\
\hline $\begin{array}{l}13.0 \\
16.0 \\
57.7\end{array}$ & $\begin{array}{r}2.1 \\
1.4 \\
1.5\end{array}$ & $\begin{array}{r}.6 \\
.3 \\
2.5\end{array}$ & $\begin{array}{l}4.1 \\
4.1 \\
5.9\end{array}$ & $\begin{array}{l}3.7 \\
3.8 \\
5.8\end{array}$ & 2i) & $\begin{array}{r}3,607 \\
3,970 \\
689\end{array}$ & $\begin{array}{r}169 \\
262 \\
35\end{array}$ & $\begin{array}{l}5.2 \\
7.3 \\
5.6\end{array}$ & $\begin{array}{r}2.838 \\
3.0601 \\
548\end{array}$ & $\begin{array}{l}3.1 \\
3.01 \\
2.7\end{array}$ & $\begin{array}{l}3 \\
3 \\
2\end{array}$ \\
\hline 27.2 & 7.7 & 2.5 & 4.8 & 4.3 & $2: 3,484$ & $2,026,875$ & 251,307 & 15.7 & $1,029,198$ & 8.4 & 1,110 \\
\hline
\end{tabular}


8. Home-purchase lending that began with a request for pre approval: Disposition and pricing, by type of home, 2004

\begin{tabular}{|c|c|c|c|c|c|c|c|c|c|}
\hline \multirow{3}{*}{ Type is hisn } & \multicolumn{3}{|c|}{ Requests for pre-approval } & \multicolumn{3}{|c|}{$\begin{array}{l}\text { Applicutisns proceddil by } \\
\text { requests for pre-approwal }\end{array}$} & \multicolumn{3}{|c|}{ 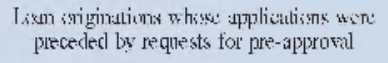 } \\
\hline & \multirow{2}{*}{$\begin{array}{l}\text { Number } \\
\text { sulbuitted }\end{array}$} & \multirow{2}{*}{$\begin{array}{l}\text { Number } \\
\text { denied }\end{array}$} & \multirow{2}{*}{$\begin{array}{l}\text { Rurent } \\
\text { clenied:- }\end{array}$} & \multirow{2}{*}{$\begin{array}{l}\text { Yumblher } \\
\text { subunitted }\end{array}$} & \multicolumn{2}{|c|}{ Ackid upun by kndis } & \multirow{2}{*}{ Nunter } & \multicolumn{2}{|c|}{ 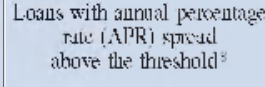 } \\
\hline & & & & & Yuunher & $\begin{array}{l}\text { Numbur } \\
\text { denied }\end{array}$ & & Nunber & Percent \\
\hline 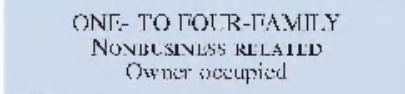 & & & & & & & & & \\
\hline 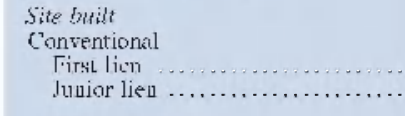 & $\begin{aligned} 684,3916 \\
88.793\end{aligned}$ & $\begin{array}{r}153,773 \\
15.423\end{array}$ & $\frac{22.5}{17.4}$ & $\begin{array}{r}448.771 \\
67.757\end{array}$ & $\begin{array}{r}396.908 \\
61,771\end{array}$ & $\begin{array}{r}34.665 \\
4.728\end{array}$ & $\begin{array}{r}332,8144 \\
52,671\end{array}$ & $\begin{array}{l}27,340 \\
14,865\end{array}$ & $\begin{array}{r}8.2 \\
28.2\end{array}$ \\
\hline 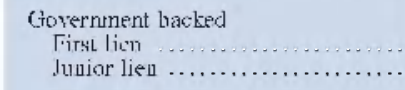 & $\begin{array}{r}100.118 \\
147\end{array}$ & $\begin{array}{r}26,682 \\
35\end{array}$ & $\begin{array}{l}26.7 \\
23.8\end{array}$ & $\begin{array}{r}71,632 \\
118\end{array}$ & 64,214 & $\begin{array}{r}7.218 \\
13\end{array}$ & $\begin{array}{r}53,527 \\
83\end{array}$ & $66 \frac{2}{7}$ & $\begin{array}{l}1.2 \\
8.4\end{array}$ \\
\hline 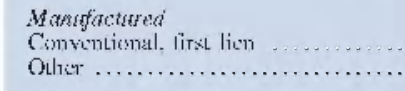 & $\begin{array}{r}39,791 \\
3.714\end{array}$ & $\frac{23.838}{935}$ & $\begin{array}{l}509 \\
55.2\end{array}$ & $\begin{array}{r}37.502 \\
2012\end{array}$ & $\begin{array}{r}35,700 \\
2.351\end{array}$ & $\begin{array}{r}22,1999 \\
419\end{array}$ & $\begin{array}{l}7,430 \\
1,787\end{array}$ & $\begin{array}{r}4,735 \\
9.9\end{array}$ & $\begin{array}{r}63.7 \\
5.3\end{array}$ \\
\hline Nonower accupied & & & & & & & & & \\
\hline 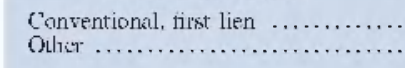 & $\begin{array}{r}84.763 \\
7,7013\end{array}$ & $\begin{array}{r}15,252 \\
1,1067\end{array}$ & $\begin{array}{l}18.01 \\
15.2\end{array}$ & $\begin{array}{r}58.101 \\
5.053\end{array}$ & $\begin{aligned} 51,548 \\
5,140\end{aligned}$ & $\begin{array}{r}5.457 \\
487\end{array}$ & $\begin{array}{r}41,564 \\
4,0100\end{array}$ & $\begin{array}{l}3.478 \\
1,3017\end{array}$ & $\begin{array}{r}8.4 \\
32.7\end{array}$ \\
\hline 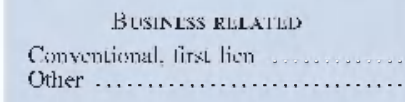 & $\begin{array}{l}3,667 \\
1.541\end{array}$ & $\begin{array}{l}350 \\
11.7\end{array}$ & $\frac{9.5}{7.6}$ & $\begin{array}{l}3.317 \\
1.419\end{array}$ & $\frac{2,791}{1,2018}$ & $\begin{array}{r}244 \\
901\end{array}$ & $\begin{array}{l}2,417 \\
1,1,769\end{array}$ & $\begin{array}{l}364 \\
1.49\end{array}$ & $\begin{array}{l}15.1 \\
13.8\end{array}$ \\
\hline 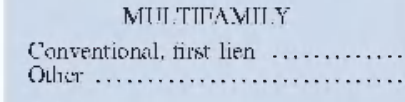 & $\begin{array}{r}326 \\
16\end{array}$ & 39) & $\begin{array}{l}12.8 \\
25.8\end{array}$ & $\begin{array}{r}2017 \\
14\end{array}$ & $\begin{array}{r}186 \\
1.3\end{array}$ & $\begin{array}{r}14 \\
2\end{array}$ & $\begin{array}{r}167 \\
11\end{array}$ & $\begin{array}{l}19 \\
6\end{array}$ & $\frac{11.4}{54.5}$ \\
\hline Tontal $\ldots \ldots \ldots \ldots \ldots \ldots$ & $1,014.084$ & 237,3015 & 23.4 & 697,793 & 621,919 & 75.376 & 497,540 & 53.1026 & 10.7 \\
\hline $\begin{array}{l}\text { Note: Excludes transition-period req } \\
\text { ted before } 2004 \text { ). See also notes } 4,5 \text {, an } \\
\text { related, nonowner-occupied, and multif } \\
\text { table } 2 \text {. } \\
\text { 1. These applicualisms are included in } \\
\text { table } 7 \text {. }\end{array}$ & $\begin{array}{l}\text { ests for pre } \\
6 \text { of table } \\
\text { nily proper }\end{array}$ & $\begin{array}{l}\text { pproval (th } \\
\text { or details } \\
\mathrm{s} \text { and gen } \\
6,10 ?, 190\end{array}$ & $\begin{array}{l}\text { submit- } \\
\text { usiness- } \\
\text { note to } \\
\text { mLud in }\end{array}$ & $\begin{array}{l}\text { 2. Nun } \\
\text { 3. Sou } \\
\ldots . \mathrm{N}\end{array}$ & $\begin{array}{l}\text { er denied d } \\
\text { lyle } 7 \text {, niale } \\
\text { applicalle. }\end{array}$ & ed by nu & ar inot shor & rili acted up & \\
\hline
\end{tabular}

of the information that might explain variations in the prices of reported loans. Among the factors reflected in loan pricing are the cost of the funds to be lent, credit risk, prepayment risk, overhead expenses, loanservicing costs, the negotiating abilities and inclinations of the creditor and borrower, the possibility of discriminatory pricing, and variations in the channels through which a loan application at a given lender may be processed (see box "Reasons for Loan Price Variation").

Issues Raised by Expanding the Disclosure of Pricing-Related Items

Although disclosures that are more comprehensive could improve the understanding of loan pricing, it would impose new costs on lenders to collect and report the additional data, raise difficult reporting issues, and might pose privacy concerns for consumers and reveal otherwise nonpublic information about lenders' business strategies. Adding new data elements to mandated disclosures would require institutions to train staff, modify data collection and reporting software, and expand controls to ensure the reporting of correct data.

Further, the fact that lenders differ in the factors they consider in setting loan prices makes it difficult to select additional data elements that would allow a complete understanding of the determinants of a particular lender's pricing method. Also, some loanpricing items that might be added to the HMDA data raise technical issues about what, precisely, to report. For example, if lenders were required to report credit scores, getting consistent data across lenders would be difficult because institutions rely on different types of credit scores in underwriting - for example, some lenders rely on generic FICO credit history scores (see text note 31 ), whereas others use proprietary credit scores developed from information on their own experience with lending. 


\begin{tabular}{|c|c|c|c|c|c|c|c|c|c|c|c|}
\hline \multicolumn{7}{|c|}{ 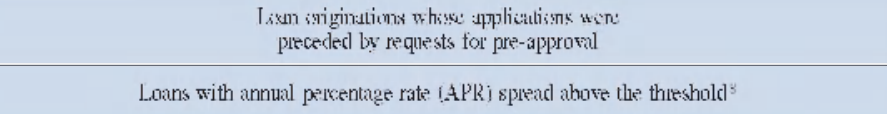 } & \multicolumn{5}{|c|}{ 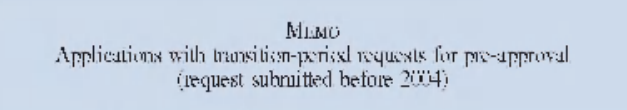 } \\
\hline & \multicolumn{4}{|c|}{$\begin{array}{l}\text { Pereent distribution, } \\
\text { hy precentiste prints af APR spisud }\end{array}$} & \multicolumn{2}{|c|}{$\begin{array}{l}\text { APR spread } \\
\text { !putcentige puintxi }\end{array}$} & \multirow[b]{2}{*}{ Yumber } & \multirow[b]{2}{*}{$\begin{array}{l}\text { Nunher } \\
\text { deried }\end{array}$} & \multirow[b]{2}{*}{$\begin{array}{l}\text { Percent } \\
\text { drivid: }\end{array}$} & \multicolumn{2}{|c|}{ Louns originated } \\
\hline $3-3.90$ & $4-490$ & $5-6.99$ & $7-8.94$ & 9or nore & Hean & Meclian & & & & Number & $\begin{array}{l}\text { Percent } \\
\text { with \& \&PR } \\
\text { spread } \\
\text { uhume } \\
\text { thireshold }\end{array}$ \\
\hline $\begin{array}{l}40.2 \\
\cdots\end{array}$ & $\begin{array}{l}28.4 \\
\cdots\end{array}$ & $\begin{array}{l}2010 \\
81.3\end{array}$ & $\begin{array}{r}2.0 \\
16.7\end{array}$ & $\frac{.5}{2.01}$ & $\begin{array}{l}4.3 \\
6.2\end{array}$ & $\begin{array}{l}4.0 \\
6.01\end{array}$ & $\begin{array}{r}20,444 \\
\left.1.26^{i}\right)\end{array}$ & $\begin{array}{r}731 \\
37\end{array}$ & $\begin{array}{l}4.3 \\
3.4\end{array}$ & $\begin{array}{r}1.3382 \\
919\end{array}$ & $\begin{array}{l}3.8 \\
3.6\end{array}$ \\
\hline $\begin{array}{l}34.1 \\
\cdots\end{array}$ & $\begin{array}{r}7.4 \\
\cdots\end{array}$ & $\begin{array}{l}20.5 \\
71.4\end{array}$ & $\begin{array}{l}28.5 \\
1.4 .3\end{array}$ & $1 . .5$ & $\begin{array}{l}5.6 \\
6.4\end{array}$ & $\begin{array}{l}6.3 \\
5.3\end{array}$ & $\begin{array}{r}5,866 \\
1.1\end{array}$ & $\begin{array}{r}351 \\
1\end{array}$ & $\begin{array}{r}7.2 \\
10.0\end{array}$ & $\begin{array}{r}3.770 \\
i\end{array}$ & 1.4 \\
\hline 19.6 & 2.4 & 33.5 & 15.2 & 8.3 & 5.8 & 5.3 & 172 & 23 & 18.4 & 91 & 22.9 \\
\hline 20.2 & 0 & 77.7 & 2.1 & 9 & 5.0 & 5.3 & 508 & 26 & 6.5 & 335 & 0 \\
\hline $\begin{array}{c}48,0 \\
0\end{array}$ & 21.8 & $\begin{array}{l}17.01 \\
53.8\end{array}$ & $\begin{array}{r}7.7 \\
38.5\end{array}$ & $\begin{array}{l}5.4 \\
7.7\end{array}$ & 4.8 & $\begin{array}{l}4.1 \\
6.8\end{array}$ & $\begin{array}{r}2.496 \\
184\end{array}$ & 107 & $\begin{array}{l}5.4 \\
5.8\end{array}$ & $\begin{array}{r}1.4933 \\
81\end{array}$ & $\begin{array}{r}4.8 \\
18.5\end{array}$ \\
\hline $\begin{array}{c}368 \\
.7\end{array}$ & 19.8 & $\begin{array}{l}31.0 \\
82.6\end{array}$ & $\begin{array}{r}8.2 \\
1.1 .4\end{array}$ & $\begin{array}{l}4.1 \\
5.4\end{array}$ & $\begin{array}{l}5.1 \\
6.4\end{array}$ & $\begin{array}{l}4.6 \\
6.3\end{array}$ & $\begin{array}{r}1,8001 \\
570\end{array}$ & $\begin{array}{l}75 \\
21\end{array}$ & $\begin{array}{l}4.6 \\
4.2\end{array}$ & $\begin{array}{r}1,393 \\
4501\end{array}$ & $\begin{array}{l}3.2 \\
4.7\end{array}$ \\
\hline 47.4 & 31.6 & $\begin{array}{l}101.5 \\
50,0\end{array}$ & $\begin{array}{c}0 \\
5010\end{array}$ & $\underset{0.5}{10.5}$ & 5.1 & $\begin{array}{l}4.1 \\
6.9\end{array}$ & $\begin{array}{r}16 \\
1\end{array}$ & $\begin{array}{l}0 \\
0 \\
0\end{array}$ & $\begin{array}{l}0 \\
0 \\
0\end{array}$ & $\begin{array}{r}15 \\
1\end{array}$ & $\begin{array}{l}6.7 \\
0\end{array}$ \\
\hline 31.0 & 18.4 & 39.5 & 9,0 & 2.1 & 5.1 & 5.0 & 33,247 & 1.380 & 5.0 & 21.93y & 3.8 \\
\hline
\end{tabular}

The potential for compromising consumer privacy is also a consideration. More than 90 percent of the loan records in a given year's HMDA data are unique- that is, an individual lender reported only one loan in a given census tract for a specific loan amount. These unique loan records can be matched with other publicly available information, such as property deed records, to determine the identities of individual borrowers. With such a match, any data item in the HMDA database, such as loan pricing, becomes publicly known. During the Board's review of Regulation C, some commenters cited this circumstance as a reason not to require the reporting of price information. Expanding HMDA to include data items such as credit scores that may be considered highly personal would likely also raise privacy concerns.

Finally, requiring lenders to disclose additional information about their lending activities may result in the disclosure of otherwise nonpublic information about lenders' business strategies. HMDA now requires disclosure of information about lending patterns-for example, pricing patterns-that other- wise would not be public. In general, such disclosure is pro-competitive because it helps possible entrants to the market identify business opportunities and lowers the information advantage of market incumbents. An argument could be made that disclosing detailed information about lenders' business strategies through HMDA might discourage lenders from testing new products or entering new markets by creating a risk that, because of such disclosure, a lender would lose its competitive advantage before it had recouped the fixed costs of entry. The likelihood of such discouragement would depend critically on whether potential competitors could discern the essential elements of a lender's business strategy (a discernment that would depend, in part, on which data items had to be disclosed) and, further, distinguish successful business strategies from unsuccessful ones (a distinction that could not be made on the basis of HMDA data alone). Ultimately, any decision to add data items to the reporting requirements of HMDA should be based on a careful weighing of the costs and benefits of such additional reporting. 


\section{Reasons for Loan Price Variation}

As in credit underwriting, loan pricing reflects a wide variety of factors.

Cost of funds. The cost of funds is the largest element in the overall cost of extending prime-market home loans and a significant factor for loans in the higher-priced segment of the market. Funding costs vary with the expected duration of the debt and the creditworthiness of the borrower. Also, many creditors originate loans for subsequent sale in the secondary market; consequently, the prices offered by secondary-market participants for home loans bear heavily on the pricing decisions for such loans.

Credit risk. Credit risk is the probability that a loan will go into default. Loans that involve greater credit risk carry higher prices. On average, loans in the prime market entail substantially lower credit risk than do those in the anbrime market. ${ }^{1}$ Interest rates on loans increase with the rate of serious delinquency, even for subprime loans, an indication that loans that pose greater credit risk carry higher rates of interest (chart $\mathrm{A}$ ).

Credit risk is a function of the creditworthiness of the borrower, the equity in the home securing the loan, and the likelihood that proceeds of a foreclosure sale of the home will satisfy the obligation if default occurs. In general, the

1. See Am Crews Cutts aud kobert Van Order i 3 jiiti, "On the Ecounmiss of Subprime Lending," Freddie Mac Working Paper 1+-01. Washi ugton:

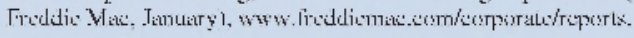

A. Percentage of selected subplime loans delinquent ninety days or mole or in forcelosure. by interest rate on loan. May 2005

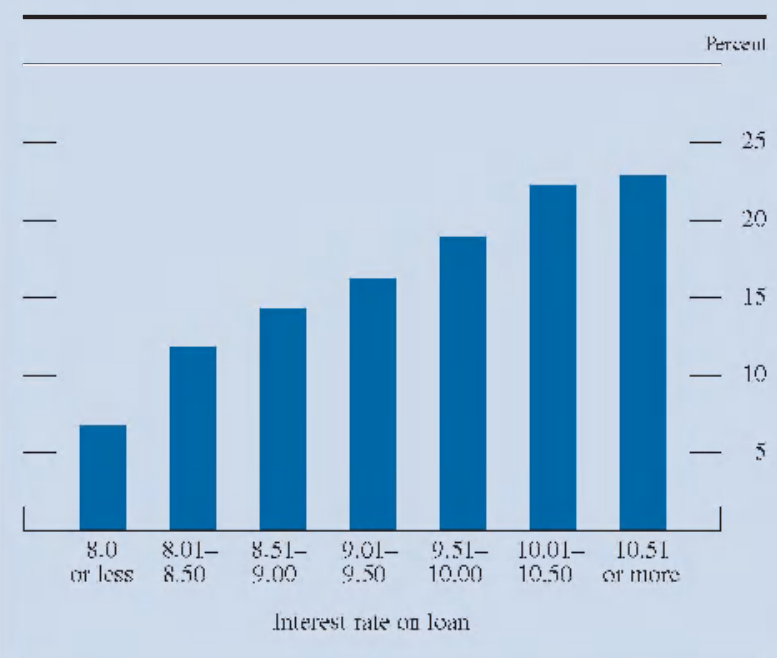

Nom: "lhe loans, whibh comsist ol' 1.5 milliom home loxuns limm among twenty-five active subprime lenders, an first- and scond-lien homepurchase and home-refinancing loans miginated in the scoond quarter of 2001. L'erliomance is as ol May 2005.

Soukt H: T.oanPertormance datahase (wwy I Ianpertormance comi. creditworthiness of borrowers is related to their income and employment prospects; available assets if financial problems arise; claims on their income from servicing other debts; and credit history, which, in part, reflects their willingness and ability to repay credit. As noted, in underwriting loans, credit history is often summarized and measured by a credit history score. Equity in a home is measured at the time of loan origination by a loan-to-value ratio (LTV).

The importance of credit history in loan pricing is illustrated by the fact that interest rates are higher for loans with lower credit history scores (chart B). For the most part, borrowers in the prime segment of the market have credit history scores that indicate they pose relatively little credit risk. Borrowers in the higher-priced segment of the market typically have weaker credit history profiles for one or more of several reasons: previous failures to make loan payments as scheduled, collection agency actions, bankruptcy or adverse court judgments, or little or no previous experience with credit.

Prepayment risk. Prepayment risk measures the possibility that a loan will be repaid before the end of the loan term. Most early payoffs of home loans are attributable either to the sale of the home or the refinancing of the loan, typically when rates have fallen sufficiently from the rate on the existing loan. Because a prepayment results in payment of the principal ahead of schedule, the lender (or secondarymarket investor) must reinvest the funds at the new market rate, which may be lower than the old rate, particularly in the case of a refinancing.

B. Inlerest rates oflered on thirly-year lixed-rate mortgages, by cedit history score of bollower, July 2005

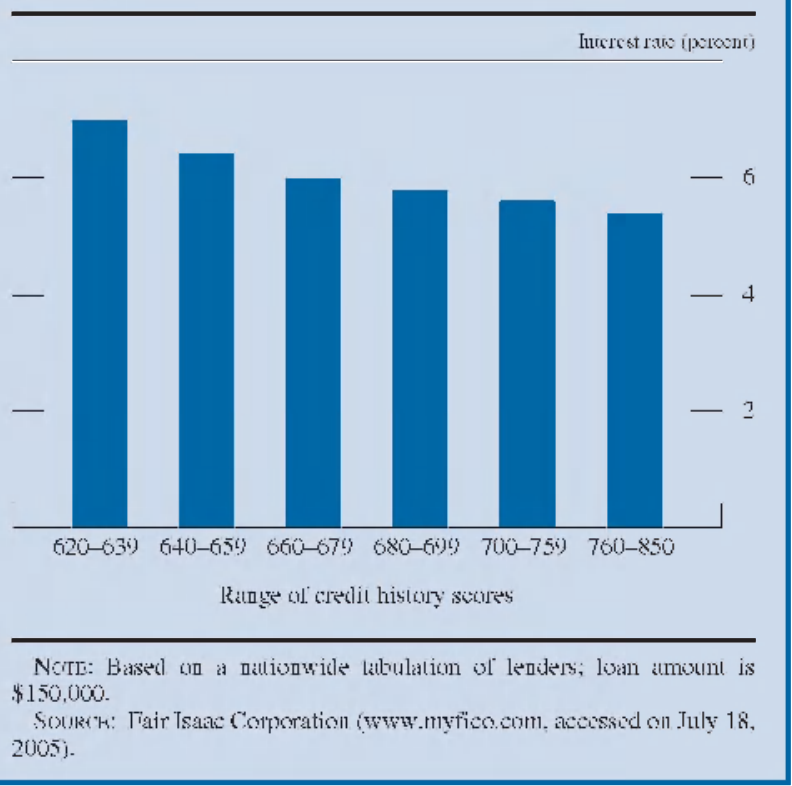




\section{Reasons for Loan Price Variation-Continued}

Although the possibility of prepayment is well understood, estimating when it will happen is quite difficult. For this reason, lenders compensate for the risk either by including prepayment penalties in their loan contracts or by pricing the risk in their calculation of the interest rate on the loan. The first of these options, the prepayment penalty, is rare in the prime segment of the market but is more common in the subprims segment.

Borrowers in the higher-priced segment of the home-loan market have higher prepayment rates than others because many of them improve their credit profiles over time as they make regular payments, and this improvement in turn allows them to qualify for a lower-rate loan. Our review of depersonalized credit record information from one of the three national credit-reporting agencies indicates that, as of June 30, 2003, almost one-fourth of those with outstanding home-loan debt and with credit history scores between 580 and 620 (a credit score range associated with individuals with 3 ubprime credit quality) increased their credit scores 40 points or more over the ensuing eighteen-month period. A change in credit score of this magnitude would typically be sufficient to move their credit risk profiles into the near-prime or prime segment of the market. ${ }^{2}$

The effect of even a small improvement in the credit history score is much larger for borrowers in the higherpriced segment of the home-loan market than for those in the prime segment. For a higher-priced loan, a small improvement in the borrower's credit history score may translate into a substantial reduction in interest rates and may encourage prepayment (chart B). ${ }^{3}$ Because pricing in the prime segment varies little by credit score, borrowers in the prime market are less likely to obtain a lower-priced loan if their credit scores improve.

Another factor that may result in elevated rates of prepayment in the higher-priced portion of the market is the practice referred to as "loan flipping." Flipping is inducing a borrower to refinance a loan repeatedly-even though the refinancing may not be in the borrower"s interest-and charging high fees with each refinancing.

Overhead expenses. Overhead expenses represent a fairly small component of the cost of lending for most home loans. However, borrowers who have experienced payment problems in the past, or who have little or no credit history, or who are unable or unwilling to document their employment histories or income are likely to require more time to underwrite. The higher cost of underwriting may be passed on to such borrowers and can result in prices that place their loans in the higher-priced segment of the market. Marketing

2. The three uational credit-reportiug agencies are Equifax

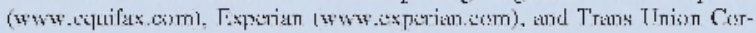

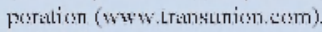

3. Of course, prepayment peualties may deter prepaymeut amoug some

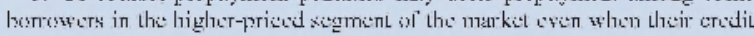
scores improve. and other expenses incurred to identify market opportunities and solicit customers may also differ across segments of the home-loan market.

Servicing costs. Servicing costs are expenses incurred to process and distribute loan payments, monitor accounts, and deal with borrowers who fall behind in their payments. Servicing costs can be particularly high if the loan involves a foreclosure-that is, a forced sale. Because the higherpriced segment of the market has high rates of serious delinquency, servicing costs are higher than in the prime market. And because higher-priced loans tend to be smaller than prime loans, the costs of servicing and the costs of extra underwriting efforts (noted earlier) must be spread over a smaller dollar volume of loans. Borrowing a relatively small amount increases the possibility that elevated costs will lead to a higher-priced loan because any given amount of fixed costs passed on to the borrower increases the APR more on a smaller loan than on a larger loan. Hence, these costs have a larger effect on loan prices in the higher-priced segment of the market than in the prime segment.

In general, the cost and risk-related factors noted earlier may be measured in an objective way and are demonstrably related to the costs, and hence the prices established, for credit. Two additional, and related, pricing factors are not necessarily objective and, moreover, are more likely than others to raise fair lending concerns: discretionary pricing by loan officers and price negotiations between creditor and applicant.

Discretionary pricing. Many creditors provide their loan officers and agents working on their behalf (for example, mortgage brokers) with rate sheets that indicate the creditors' minimum prices by product (for example, for conventional loans of various types or with various types of government backing), loan characteristics (for example, term to maturity and LTV ratio), and borrower creditworthiness (for example, credit history score and debt-to-income ratio). In some cases, loan officers and brokers are allowed to deviate from these prices as market conditions warrant or allow. A loan officer may quote a prospective borrower a price above the rate sheet (sometimes referred to as an "overage"), and if the consumer accepts the price without demanding cash back to offset loan fees or other closing costs, the contract interest rate or loan fees on such "overaged loans" will be higher than they might otherwise have been.

Discretionary pricing can be a legitimate business practice and can help ensure that markets allocate resources in the most efficient way. However, when loan officers are permitted latitude in establishing prices, the lender runs the risk that differential treatment on a basis prohibited by law may arise. Obtaining overages more often, or in higher 


\section{Reasons for Loan Price Variation-Continued}

amounts, from minority borrowers or targeting only minorities for wetaging may constitute a fair lending violation unless some legitimate, nondiscriminatory reason exists for the result.

Price negotiations. Price variation can also arise because less sophisticated or less knowledgeable borrowers are not as likely to shop for credit or to realize that they may negotiate with the lender over the interest rate and fees. Moreover, lower-income borrowers may be disproportionately represented in the category of less sophisticated borrowers. Given that minority borrowers have disproportionately lower incomes, there is some likelihood that they will be werrepresentec among borrowers with weragec loans. Such results may be interpreted by some as demonstrating unlawful discriminatory pricing by lenders.

Differences in the extent to which borrowers negotiate or shop for the best deal may result in a pattern of overage loans that is not illegal but that nonetheless may be difficult for a lender to document and explain. Moreover, instances of different negotiating strengths among borrowers can be difficult to distinguish from illegal discriminatory treatment in which loan officers quote loan rates or provide information or assistance that varies according to the race, ethnicity, sex, or other prohibited characteristic of the borrower.

Variations in loan-processing channels. The delivery channels through which borrowers obtain loans vary widely across lenders. On the one hand, underwriting and pricing may be centrally controlled even though the application may begin on the Internet or with a mailed solicitation or at a bank branch. On the other hand, in complex financial organizations with bank branches, multiple affiliates, decentralized loan production offices, indirect brokerage operations, and ronbark subsidiaries, each application may be subject to a different underwriting and pricing regime depending on its point of initiation. The 2004 HMDA pricing data suggest that the delivery channel through which a borrower obtains a loan may matter. As discussed elsewhere in this article (see section "Incidence of Higher-Priced Lending for Selected Subgroups"), the incidence of higher-priced lending is higher for borrowers who live outside the assessment areas of lenders covered by the Community Reinvestment Act of 1977 (CRA) than for those who live inside these areas. ${ }^{4}$ This difference may be due to a reliance on different delivery channels for loans within and outside these lenders' assessment areas.

4. Lihe assessmeut areas of lenders covered by the C'RA iuclude priucipally bue lecales in which a lender has its main er lyanch affiess and its deposit-taking automated teller machiues. For a more complete detiuition of CRA assessmeut areas, see the Federal Reserve Board's Regulation B.ti.

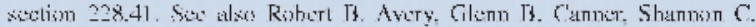
Mok, and Lan S. Sokolov i Zilisi, "Community tianks and Rural Levelopment: Research Relating to Proposals to Revise the Regulations 'That Lmple-

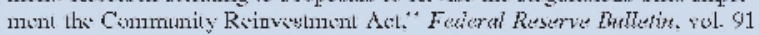
(Spring), p?. 20?2:5

\section{The Interest Rate Situation in 2004}

The interest rates prevailing in a given year can significantly affect the proportion of loans that exceed the thresholds established by the Federal Reserve for determining whether a loan is "higher-priced." For 2004 , the rate on Treasury securities used to calculate the spread for home loans with thirty-year terms varied from 4.67 percent to 5.54 percent. This variation implies that the threshold for reporting a firstlien loan as higher-priced ranged from 7.67 percent to 8.54 percent over the year. For junior liens, which typically have a shorter term to maturity than do first liens, the reporting threshold ranged from about 8.78 percent to 9.79 percent for a fifteen-year loan (different terms to maturity would yield somewhat different ranges).

Data derived by Freddie Mac from its Primary Mortgage Market Survey show that the spread for average interest rates for first-lien conforming mortgages extended in 2004 imply a typical gap between the thirty-year Treasury rate and an estimated APR for prime-rate loans of between 1 percent and
1.25 percent ${ }^{40}$ This gap implies that a thirty-year first-lien home loan would have to have been priced between 1.75 percentage points and 2 percentage points above a prime-rate home loan to exceed the HMDA price-reporting threshold. Such a price spread was around the upper end of the near-prime market, but it was probably still below the levels associated with most subprimc loans. In future years, the thresholds may cover a greater proportion of the near-prime segment of the market.

\section{Results: The Incidence of Higher-Priced Lending}

Several patterns are revealed in the 2004 HMDA pricing data (table 7). First, in almost all cases, government-backed loan products show lower incidences of higher-priced lending than do comparable conventional loan products. For example, among first-lien home-purchase loans for site-built homes, 11.5 percent of conventional loans have APRs above

40. See www fredtiemac.com. 
the pricing threshold versus only 1.3 percent of government-backed loans. Second, with few exceptions, first-lien loans have a substantially lower incidence of higher-priced lending than do junior-lien loans for the same purposes. For example, nationally the incidence of higher-priced lending for conventional first-lien refinance loans was 15.5 percent whereas for comparable junior-lien loans it was 27.4 percent. Third, manufactured home loans exhibit the greatest incidence of higher pricing across all loan products, a result consistent with the elevated credit risk associated with such lending. For example, 57.1 percent of conventional first-lien loans used to purchase manufactured homes were higher priced, in sharp contrast to the 11.5 percent rate for comparable loans for site-built homes. Finally, the lower incidence of higher-priced lending (shown in the memo item in table 7) for loans initiated in the transition period reinforces the decision to exclude such loans from the pricing analysis.

Rate spreads for higher-priced loans. Variation in mean and median spreads across products for loans with rates above the threshold is much smaller than variation in the incidence of higher-priced lending. Because the threshold for reporting is set higher for junior liens than for first liens, higher-priced juniorlien products have higher mean and median spreads. Once again, manufactured-home loans stand out in that they have the highest average spreads among all the loan products with comparable lien status.

Except for loans backed by manufactured homes, the vast majority of higher-priced loans have prices within 1 or 2 percentage points of the pricing thresholds. Only a very small proportion of higher-priced first-lien loans have spreads that exceed 7 percentage points. Similarly, only a small proportion of juniorlien loans have spreads of 9 percentage points or more: But home-improvement loans provide two exceptions-30.7 percent of conventional juniorlien home-improvement loans and 47.6 percent of government-backed junior-lien home-improvement loans have spreads of 9 percentage points or more. Reflecting these distributions, the mean and median spreads for most loan products fall within 2 percentage points of the reporting thresholds. The exceptions include loans backed by manufactured homes and junior-lien home-improvement loans, for which the distribution of prices is more even.

Lenders of higher-priced loans. Most lenders covered by HMDA reported extending few if any higherpriced loans for 2004 (data not shown in tables). Nearly 3,300 lenders reported making no such loans, and an additional 2,300 reported making between one and nine such loans. Nearly 500 lenders reported making more than 100 higher-priced loans; these more-active lenders accounted for 96 percent of all reported higher-priced lending of this type. Moreover, the 10 lenders with the largest volume extended 38 percent of all higher-priced loans.

Variation across metropolitan areas. The analysis of separate geographic markets shows that higherpriced lending varies considerably across MSAs. ${ }^{41}$ For this exercise, the focus is on the incidence of higher-priced lending among conventional first-lien home-purchase loans for site-built, owner-occupied homes. The MSA with the lowest incidence of higher-priced lending for this product is the San Francisco-San Mateo-Redwood City area in California, at 2 percent; the MSA with the highest incidence is the McAllen-Edinburg-Pharr area in Texas, at 42 percent ${ }^{42}$ A review of the full list of MSAs indicates that most of the areas with the highest incidence are in the southern region of the country, whereas those with the lowest incidence are much more dispersed.

Although a comprehensive analysis of the reasons for such wide variation in the incidence of higherpriced lending is beyond the scope of this article, a review of data from one of the three national creditreporting agencies finds a close association between the proportion of individuals in an MSA county with a low credit score and the incidence of higher-priced lending in that area.

\section{Loans Covered by HOEPA}

The 2004 HMDA data indicate whether a loan is subject to the Home Ownership and Equity Protection Act of 1994. Before 2004, little information was publicly available about the extent of such lending or the number or type of institutions involved in such activities. However, HMDA data do not capture all HOEPA-related lending. Some HOEPA loans are extended by institutions not covered by HMDA, and some HOEPA loans that are made by HMDA-covered institutions are not reported under the Federal

\footnotetext{
41. Reporting instilutions are required to report all their lenting in MSAs as well as in the nonmelropolitan portions of states. However, bccauss: institutions opsrating sxclusivaly in nommetropolitan artas are nol covered by HMTDA, loans in nonmetropolitan areas are underrepresented in the data. For this reason, the geographic analysis here is focusted on MSAs.

42. In Nowntwer 2004. the OMB redesignated this Thas MSA as McAllen-Fdinburg-Mission (see www whilehouse.govfomb/bulletins/ 「yos/b05-02_altachment.pd「\}.
} 
Reserve Board's Regulation C, which implements HMD'A. In particular, if the proceeds of a homesecured loan are not used to refinance an existing home loan or to finance home improvement, then the loan may be covered by HOEPA but is not reportable under Regulation C. ${ }^{43}$

\section{Incidence of HOEPA-Related Lending}

For 2004, 1,948 lenders reported extending 24,594 loans covered by HOEPA (table 7). The HOEPA loans accounted for only 0.003 percent of all the originations of home-secured refinance or homeimprovement loans reported for 2004 (derived from the table) ${ }^{4+}$

HOEPA lending is relatively concentrated: The ten lenders that reported the largest number of HOEPA originations accounted for 37 percent of all reported HOEPA loans (data not shown in tables). 'At the other extreme, 801 institutions reported only one HOEPA loan, and 327 reported only two such loans. Most HOEPA loans were extended by banks ( 50 percent of the total) or by bank subsidiaries or affiliates of bank holding companies (14 percent of the total); independent mortgage companies extended the rest.

\section{Characteristics of HOEPA-Related Lending}

'As noted, HOEPA applies only to closed-end home loans (whether for refinancing or home improvement) and not to home-purchase loans or home equity lines of credit. The vast majority of HOEPA loans reported in the 2004 data involved conventional products: Only 7 percent of reported HOEPA loans were government backed (derived from table 7). 'About 50 percent of the reported HOEPA loans involved first-lien conventional loans (more than 80 percent of these were for refinancings, and the rest were for home improvement), and about 40 percent involved junior-lien conventional loans (more than half of these were for home improvement).

On average, reported HOEPA loans are not large (data not shown in tables). For example, for conventional refinancing loans covered by HOEPA, the

43. For example, if a homeowner takes out a HOF.PA-covered loan to pay off oulstanding credil card debl or some olher lype of consumer crodit. and the loan does not involve the refinancing of an tristing home loan or home improvememt, then the loam is nol coveled by Regulation $C$ and is thes nol required lo be part of an institution's IIMI $/$ reporting.

44. Lhe IIML $\lambda$ data also includs information on loans purchased by covered instilutions turing 2004: Among purchased loans, alwout 2,700 were designated as HOF.PA loans. average size of a first-lien loan was $\$ 98,650$, and the average size of a junior-lien loan was $\$ 31,705$. In contrast, the average sizes of such loans not covered by HOEPA were $\$ 173,125$ for a first-lien loan and $\$ 54,581$ for a junior-lien loan.

Reported HOEPA lending varies among borrowers sorted by borrower income, race, and ethnicity and among census tracts sorted by census tract income, population, and location. However, the data do not indicate that HMD'A-reportable HOEPA lending is focused primarily on lower-income or minority individuals or on those residing in lower-income neighborhoods or neighborhoods with high concentrations of minority individuals. For example, although reported HOEPA loans were extended to borrowers in all income groups, about three-fourths were extended to middle- and higher-income borrowers (data not shown in tables). Similarly, most reported HOEPA loans were extended to non-Hispanic white borrowers. Most of the homes secured by reported HOEPA loans were in middle- or higher-income areas and in areas with a minority population that was less than 20 percent of the total population.

\section{LENDING OUTCOMES BY. RACE, ETHNICITY, 'AND SEX}

One of the primary purposes of the HMD'A data is to allow comparison of the outcomes of the lending process for applicants and borrowers grouped along many dimensions, including by race, ethnicity, and sex. Outcomes reported in the HMD'A data include the disposition of applications (denial rates) and, as of 2004 , the pricing of loans. Gross outcomes for different groups of borrowers can be compared, but HMD'A data include information on a number of items whose presence or absence for borrowers can be made consistent ("controlled for") in conducting the comparisons. Clearly the HMD'A data do not include all the factors that are involved in credit underwriting and pricing. However, by controlling for variations so as to make borrowers as similar as possible on the dimensions of the data that are available, one can account for some of the factors that may explain differences in the outcomes of the lending process among groups.

The HMD'A data allow individuals to be matched by loan type and purpose, type of property securing the loan, lien status, owner-occupancy status, property location (for example, same MS'A or even same census tract), income relied on for underwriting, loan amount, and time of year when the loan was made as well as by whether the loan involved a co-applicant. 
In comparing lending outcomes across racial and ethnic groups, one can match for the sex of the applicant and co-applicant, and in comparing outcomes by sex, one can match for race and ethnicity.

Comparisons in outcomes across groups can be conducted at the level of an individual institution, groups of institutions (for example, manufacturedhoms lending specialists), geographic market, or populations as a whole. Further, a variety of statistical methodologies can be used to control for the effects of the credit-related or other factors in HMDA noted above. The full range of these comparisons is beyond the scope of this article. However, to gain an understanding of the differences that are likely to be important, we analyzed the 2004 data using statistical matching criteria similar to those used in the Federal Reserve's statistical analysis program (described in the section "Using the Expanded HMDA Data as a Screening Tool for Fair Lending Enforcement").

We restrict the analysis to denial rates, the incidence of higher-priced lending, and the mean spreads paid by borrowers with higher-priced loans, and we compare these outcomes across eleven groups - nine racial or ethnic groups and the two sexes. We conduct the analysis for thirteen of the twenty-five loan products covered in table $7 .^{45}$

We present the comparisons at three levels, one unadjusted and two adjusted. The first level for each group is the raw, or unadjusted, average outcome. The second level is the average outcome as adjusted for the borrower-related factors reported in the HMDA data-income, loan amount, location (MSA) of the property, presence of a co-applicant, and (in the comparisons by race and ethnicity) sex or (in the comparisons by sex) race and ethnicity; applying this adjustment is hereafter termed "adjusting (or controlling or accounting) for borrower-related factors." The third level is the average outcome as adjusted for all the items in the second level (the borrower-related factors) plus the lending institution - applying this adjustment is hereafter termed "adjusting (or controlling, or accounting) for borrower-related factors plus lender."

Applications subject to the transition rules were excluded from the pricing comparisons; however, they were included for the denial-rate comparisons. ${ }^{16}$

45. The analysis was not conducted for unsecured loams because pricing data were not collected for these loams. Fleven oblher procluct artas wore not ust bocause they accounted for so tow loans that matching was difficult.

46. The action date on an application is used to thelemine the reporting year for $1 \mathrm{IMDA}$ data, Ihe gap betwen the application date and the action date is gencrally shorter for dented applications than for originated loans. For example, applications received and acted upon in December (and therefore reporled in HMT)A for that year') are more
Also excluded from the sample are applicants residing outside the fifty states and the District of Columbia, applications deemed to be business-related, and requests for pre-approval that were denied by the lender or that were granted by the lender but not acted upon by the borrower. Otherwise, the sample includes all 2004 HMDA applications acted upon by the lender in the thirteen product areas.

Unadjusted and adjusted comparisons for lending outcomes across groups are discussed in the sections below. For purposes of presentation, the adjusted outcomes shown in the tables are normalized so that, for the base comparison group (non-Hispanic whites in the case of comparison by race and ethnicity, and males in the case of comparison by sex), the adjusted mean at each adjustment level is the same as the unadjusted mean. Consequently, the adjusted outcomes for any other group represent the expected average outcome if the members of that group had the same distribution of control factors as that of the base comparison group.

\section{Denial Rates across Groups}

Unadjusted mean denial rates vary across loan categories for all groups of borrowers (table 9). For example, the mean unadjusted denial rate for Asians is lowest for government-backed first-lien homepurchase loans (12.4 percent) and highest for conventional junior liens for home improvements (46.1 percent).

For every loan category, American Indians, blacks, Hispanic whites, and the group for which race was missing have higher unadjusted mean denial rates than non-Hispanic whites, with the highest rates generally for blacks and the rates for Hispanic whites lying about halfway between those for blacks and those for non-Hispanic whites. The denial rates for each of the other minority groups vary in their relationship with the rates for non-Hispanic whites.

With few exceptions, controlling for borrowerrelated factors reduces the differences among racial and ethnic groups. (Although the effect of controlling for borrower-related factors can widen the racial and ethnic differences in denial rates.) Accounting for

likely to be demials than acceptances. Similarly, applicuations acted upon in January bul received in the previous year are more likely to be accoptances. In analyzing donial rats for 2004 . sxcluding applicaLions covered by the tramsition period (that is, applications received before 2004) is therefore likely lo disproportionately exclude acceptances. Ihis can be sen in the memo itum in table: 7. where the denial rates are lower for applications fild during the transition prion. I ior Lhis reasom, transilion-period applications are included in the denialrale analysis in tabTes 9 and 14. 
9. Unadjusted and adjusted denial rates on applications for loans on one- to four-family homes, by type of loan and by race and ethnicity and sex of applicant, 2004

A. Home purchase, owner-occupied site-built home

Percent except as noted

\begin{tabular}{|c|c|c|c|c|c|c|c|c|c|c|c|c|}
\hline \multirow{4}{*}{$\begin{array}{l}\text { Ritis ind sthmicity } \\
\text { and } s e x\end{array}$} & \multicolumn{8}{|c|}{ Commentismal } & \multirow{2}{*}{\multicolumn{4}{|c|}{ Gorernnent backed. tirst lien }} \\
\hline & \multicolumn{4}{|c|}{ Tïrst licm } & \multicolumn{4}{|c|}{ Juniun lisn } & & & & \\
\hline & \multirow{2}{*}{$\begin{array}{l}\text { Number } \\
\text { of } \\
\text { utpplicutionnx }\end{array}$} & \multirow[b]{2}{*}{$\begin{array}{l}\text { T:midjuxkisd } \\
\text { ckemial } \\
\text { rats }\end{array}$} & \multicolumn{2}{|c|}{ 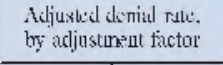 } & \multirow[b]{2}{*}{ 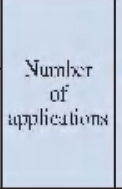 } & \multirow[b]{2}{*}{$\begin{array}{l}\text { michjusted } \\
\text { denial } \\
\text { ruts: }\end{array}$} & \multicolumn{2}{|c|}{$\begin{array}{l}\text { Adjusted demiul ralk, } \\
\text { by acliustment factor }\end{array}$} & \multirow[b]{2}{*}{$\begin{array}{c}\text { Yumber } \\
\text { of } \\
\text { urpplicatiuns }\end{array}$} & \multirow[b]{2}{*}{ 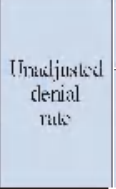 } & \multicolumn{2}{|c|}{ 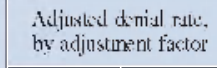 } \\
\hline & & & $\begin{array}{c}\text { Borrower- } \\
\text { nilisted }\end{array}$ & $\begin{array}{l}\text { Bstrower- } \\
\text { Ielated } \\
\text { plus. } \\
\text { lencker }\end{array}$ & & & $\begin{array}{l}\text { Borrower- } \\
\text { rislatid d }\end{array}$ & $\begin{array}{l}\text { Thinower- } \\
\text { related } \\
\text { plux } \\
\text { lender }\end{array}$ & & & $\begin{array}{l}\text { Borrower- } \\
\text { nelisted }\end{array}$ & \begin{tabular}{|c|c|} 
Pinnsswer- \\
related \\
plus \\
lencler
\end{tabular} \\
\hline \multicolumn{13}{|l|}{$\begin{array}{l}\text { Rare and ethruicity } \\
\text { American Indiau or }\end{array}$} \\
\hline Alaska Fulive & 42.450 & 21.1 & 20.4 & 15.7 & 11,211 & 22.7 & 22.6 & 18.3 & 6.425 & 15.5 & 14.4 & 14.7 \\
\hline Asian ............... & 2880.060 & 13.5 & 13.7 & 12.9 & 48.970 & 1.86 & 17.4 & 16.3 & 7.645 & 12.4 & 13.2 & 13.2 \\
\hline $\begin{array}{l}\text { Black is Afician } \\
\text { Americau }\end{array}$ & $4(2,2010)$ & 24.7 & 23.3 & 18.2 & 96,741 & 21.9) & 21.2 & 18.8 & 85,845 & 17.2 & 16.9) & 16.5 \\
\hline 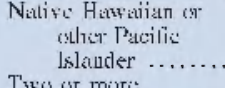 & 301.866 & 17.5 & 15.3 & 15.4 & 9.312 & 18.3 & 17.2 & 156 & $\left.3.62^{i}\right)$ & 13.8 & 12.9 & 11.7 \\
\hline $\begin{array}{l}\text { Two es mirre } \\
\text { minority races }\end{array}$ & 3.7618 & 13.8 & 13.3 & 15.7 & 475 & & & & & & 15.8 & 13.1 \\
\hline Tisint & 64.744 & 12.0 & 150 & 12.4 & 12,224 & 13.1 & 15.3 & 13.8 & $12,807 ?$ & 9.6 & 12.5 & 11.8 \\
\hline Race missing ...... & $69)(1,276$ & 21.8 & 20.1 & 15.1 & $156,5 i 4$ & 30.4 & 19.6 & 17.7 & 63.179 & $20 . j . j$ & 17.0 & 16.6 \\
\hline Hispanic while & 423,305 & 18.4 & 15.8 & 14.8 & 124,483 & 2010 & 18.1 & 160 & 50,172 & 15.6 & 13.8 & 13.5 \\
\hline Non-Ilispanis: white & $3,3109,353$ & 10.9 & 10.9 & 10.9 & 532.2610 & 13.7 & 13.7 & 13.7 & 396.856 & 10.4 & 10.4 & 10.4 \\
\hline \multicolumn{13}{|l|}{$\operatorname{Sic} x$} \\
\hline Oue male.. & $1.636,413$ & 16.8 & 16.8 & 16.8 & 344.552 & 18.7 & 18.7 & 18.7 & 155.671 & 14.0 & $14.1)$ & 14.6 \\
\hline Ons fiemale & $1,217,287$ & $16 ! !$ & 15.3 & 15.8 & 235,350 & 18.3 & 18.2 & 18.4 & 133,456 & 14.4 & 13.2 & 13.5 \\
\hline I'wo males ........ & 55.264 & 15.6 & 156 & 15.6 & 1.311 & 18.3 & 18.3 & 18.3 & $13,4(19)$ & 11.2 & 11.2 & 11.2 \\
\hline Two femalios . .... & 45,100 & 1.5 .2 & $14 ! !$ & 14.4 & 8.591 & 17.5 & 16.4 & 16.1 & 9,121 & 12.1 & 109 & 11.8 \\
\hline
\end{tabular}

NoTE: Includes transition-period applications (those submitted before 2004); for explanation, see text note 46. For explanation of adjustment factors, see text. For method of allocation into racial and ethnic categories and definitions of categories, see general note to table 6 and text note 35 . Applications made

jointly by a male and temale are not tabulated here because they would not be

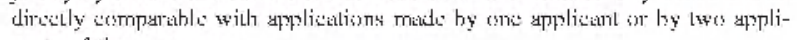
cants of the same tis.

\section{9.-Continued}

B. Refinance, owner-occupied site-built home

Percent except as noted

\begin{tabular}{|c|c|c|c|c|c|c|c|c|c|c|c|c|}
\hline \multirow{4}{*}{$\begin{array}{l}\text { Rius ind slmicity } \\
\text { and sex }\end{array}$} & \multicolumn{8}{|c|}{ Comwentisnal } & \multirow{2}{*}{\multicolumn{4}{|c|}{ Governnent backed. first lien }} \\
\hline & \multicolumn{4}{|c|}{ First lien } & \multicolumn{4}{|c|}{ Junior lien } & & & & \\
\hline & \multirow{2}{*}{$\begin{array}{c}\text { Aumber } \\
\text { of } \\
\text { utppliculimax }\end{array}$} & \multirow[b]{2}{*}{$\begin{array}{l}\text { T-miljuxtisd } \\
\text { dewial } \\
\text { ratk }\end{array}$} & \multicolumn{2}{|c|}{$\begin{array}{l}\text { Maljuxbid disnial rulk: } \\
\text { by adjustunent fiactor }\end{array}$} & \multirow[b]{2}{*}{\begin{tabular}{|c|} 
Sumbly \\
of \\
itpplicatiomx
\end{tabular}} & \multirow[b]{2}{*}{$\begin{array}{l}\text { meicljustid } \\
\text { denial } \\
\text { ratk }\end{array}$} & \multicolumn{2}{|c|}{$\begin{array}{l}\text { Adjusted denial rak: } \\
\text { by adjustment fictor }\end{array}$} & \multirow[b]{2}{*}{$\begin{array}{c}\text { Sumber } \\
\text { of } \\
\text { urpplicstivinx }\end{array}$} & \multirow[b]{2}{*}{$\begin{array}{l}\text { ITnutidiuktsid } \\
\text { clenial } \\
\text { ratis }\end{array}$} & \multicolumn{2}{|c|}{$\begin{array}{l}\text { Adjulusid donial rule, } \\
\text { by adjustunent factor }\end{array}$} \\
\hline & & & $\begin{array}{l}\text { Borrower- } \\
\text { related }\end{array}$ & $\begin{array}{l}\text { Bompowet- } \\
\text { selated } \\
\text { plus } \\
\text { lindst }\end{array}$ & & & $\begin{array}{l}\text { Borrowel- } \\
\text { related }\end{array}$ & $\begin{array}{l}\text { Thinnuwer- } \\
\text { related } \\
\text { plus } \\
\text { linds }\end{array}$ & & & $\begin{array}{l}\text { Borrower- } \\
\text { related }\end{array}$ & $\begin{array}{c}\text { Bunnssurer- } \\
\text { related } \\
\text { plus } \\
\text { linder }\end{array}$ \\
\hline \multicolumn{13}{|l|}{$\begin{array}{l}\text { Raree atuid ethaticity } \\
\text { Americau Indiau or }\end{array}$} \\
\hline $\begin{array}{l}\text { Alatka Vulive } \\
\text { Alats }\end{array}$ & 93,068 & 38.2 & 40.1 & 32.3 & 6.520 & 40.8 & 38.6 & 349 & 3,222 & 15.7 & 13.8 & 133 \\
\hline Asian ............ & 321.978 & $18 . \overline{7}$ & 25.7 & 27.3 & 20.194 & 33.1 & 36.1 & 35.2 & $3.6 \% 8$ & 15.0 & 15.4 & 16.1 \\
\hline American .... & 807.836 & 41.9 & 39.8 & 32.4 & 54,132 & 44.5 & 42.2 & 37.3 & $60,607 ?$ & 17.6 & 18.5 & 17.2 \\
\hline \multicolumn{13}{|l|}{$\begin{array}{l}\text { Native llawaiiau or } \\
\text { sillict Pacilic }\end{array}$} \\
\hline Two sis mosti & & & & & & & & & & & & \\
\hline Twint ................... & 108,225 & $\begin{array}{l}28.2 \\
25.7\end{array}$ & 330 & 31.3 & 9.382 & $\begin{array}{l}31.5 \\
289\end{array}$ & 33.0 & 39.8 & $\begin{array}{r}442 \\
7 \times 57\end{array}$ & $\begin{array}{l}13.6 \\
11.0\end{array}$ & $\begin{array}{l}13.6 \\
1.8\end{array}$ & $\begin{array}{l}14.3 \\
14.1\end{array}$ \\
\hline Race missing .... & $3 ., 684.368$ & 43.) & 47.3 & 31.3 & 193,182 & 43.8 & 41.1 & 35.2 & 55,6017 & 21.4 & 17.8 & 17.1 \\
\hline Ilispanic white & 639.075 & 206 & 31.3 & 28.6 & 38.892 & 37.9 & 37.0 & 33.8 & 26,182 & 15.8 & 15.1 & 16.2 \\
\hline Nen-Hispramic whice & 5.916 .204 & 24.3 & -4.3 & 24.3 & 475,471 & 28.4 & 28.4 & 28.4 & $206 \times 51$ & 12.4 & 12.4 & $12 . \overline{4}$ \\
\hline \multicolumn{13}{|l|}{ Sic $x$} \\
\hline Oue male. & 3.683 .328 & 35.1 & 35.1 & 35.1 & 170.812 & 37.4 & 37.4 & 37.4 & $91.6010)$ & 16.1 & 16.1 & 16.1 \\
\hline One female & $2,161,057$ & 32.2 & 31,0 & 32.8 & 1.31 .172 & 379 & 35.5 & 360 & 71.666 & 16.1 & 15.2 & 163 \\
\hline l'wo males ... & 6i) 113 & 26.9 & 26.9 & 26.9 & 5.471 & 32.7 & 32.7 & 32.7 & 4,995 & 17.4 & 17.4 & 17.4 \\
\hline Twos femalies .. & 78.731 & 30.1 & 270 & 26.1 & 5.370 & 34.4 & 32.8 & 34.2 & $4.74 !$ & 15.5 & 14.6 & 14.7 \\
\hline
\end{tabular}

NoTE: See note to table 9.A 
9. Unadjusted and adjusted denial rates on applications for loans on one- to four-family homes,

by type of loan and by race and ethnicity and sex of applicant, 2004-Continued

C. Home improvement, conventional loan, owner-occupied site-built home

Percent except as noted

\begin{tabular}{|c|c|c|c|c|c|c|c|c|}
\hline \multirow{3}{*}{$\begin{array}{l}\text { Ratie and sthmicily } \\
\text { and sex }\end{array}$} & \multicolumn{4}{|c|}{ Firsil licm } & \multicolumn{4}{|c|}{ Iunier lien } \\
\hline & \multirow{2}{*}{$\begin{array}{c}\text { Fumber } \\
\text { af } \\
\text { applicatious }\end{array}$} & \multirow{2}{*}{$\begin{array}{l}\text { Tonidjustiod } \\
\text { demial } \\
\text { rate }\end{array}$} & \multicolumn{2}{|c|}{$\begin{array}{l}\text { Adjusted devial rate. } \\
\text { by adjustment tautor }\end{array}$} & \multirow{2}{*}{$\begin{array}{c}\text { Number } \\
\text { si } \\
\text { applications }\end{array}$} & \multirow{2}{*}{$\begin{array}{l}\text { TInitjusurd } \\
\text { denial } \\
\text { rate }\end{array}$} & \multicolumn{2}{|c|}{$\begin{array}{l}\text { Adjusted deuial rate. } \\
\text { by adjustmeut tactor }\end{array}$} \\
\hline & & & $\begin{array}{l}\text { Thongiswer- } \\
\text { related }\end{array}$ & $\begin{array}{l}\text { Thrronyer- } \\
\text { related } \\
\text { plus limder }\end{array}$ & & & $\begin{array}{l}\text { Bomrouset- } \\
\text { related }\end{array}$ & $\begin{array}{l}\text { Borrinzer- } \\
\text { related } \\
\text { plus lindin }\end{array}$ \\
\hline \multicolumn{9}{|l|}{ Rare and eshatic ify } \\
\hline Americau Indian or Alaska Lative .. & 8,843 & 47.1 & 47.1 & 41.3 & 7.712 & 54.7 & 48.2 & 47.3 \\
\hline 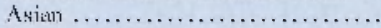 & 15.204 & 27.8 & 34.8 & 33.4 & 16,276 & 46.1 & 4.7 .7 & 44,3 \\
\hline Black is Afician American ........ & 67,098 & 49.1 & 47.2 & 41.7 & 62,045 & 60.1 & 55.6 & 520 \\
\hline $\begin{array}{l}\text { Native llawaiiau or other } \\
\text { Pacilic Tslandir }\end{array}$ & $4.4 !^{2}$ & & & & & & & 138 \\
\hline l'wo or more minority races .. & $\begin{array}{r}4,417 \\
677\end{array}$ & 41.5 & $\begin{array}{l}+2.7 \\
43.0\end{array}$ & $\begin{array}{l}3.9 \\
41.3\end{array}$ & $\begin{array}{r}4.538 \\
650_{1}\end{array}$ & $\begin{array}{l}50,1 \\
6301\end{array}$ & $\begin{array}{l}46,4 \\
57 \mathrm{ij}\end{array}$ & $\begin{array}{l}4.8 \\
48.8\end{array}$ \\
\hline 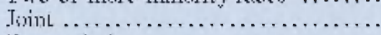 & 6832 & 32.6 & 40.2 & 34.1 & 10,842 & 40.6 & 47.1 & 42.2 \\
\hline Race missing ........................ & 1012,716 & 53.0 & 56.15 & 30.5 & 159.584 & 49.6 & 48.4 & 42.1 \\
\hline Hispramic uphile . . & 54.319 & 37.5 & 37.7 & 36.2 & $39.5 \geq 0$ & 514 & 46.4 & 4.1 \\
\hline Non-llispanic white . & 3610.959 & 28.6 & 28.6 & 28.6 & 494.636 & 36.3 & 36.3 & 36.3 \\
\hline \multicolumn{9}{|l|}{ Sex } \\
\hline Oue male ... & 150,817 & 43.4 & 43.4 & 43.4 & 189.244 & 51.1 & 51.1 & 51.1 \\
\hline Oni liemale $\quad \ldots \ldots \ldots \ldots$ & 143.959 & 38.4 & 37.19 & 399 & 143.026 & 500 & 47.3 & 49.4 \\
\hline l'wo males $\ldots \ldots \ldots \ldots \ldots \ldots \ldots \ldots$ & 5,024 & 39).1 & 39.1 & 3i). 1 & 5.588 & 46.3 & 46.3 & 46.3 \\
\hline 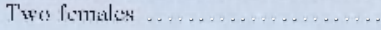 & 5.788 & 38.4 & 37.5 & 34.6 & 6,261 & 44.3 & 42.9 & 44.9 \\
\hline
\end{tabular}

Note: See note to table 9.A.

\section{9.-Continued}

D. Manufactured housing, conventional loan, first lien, owner-occupied home

Percent except as noted

\begin{tabular}{|c|c|c|c|c|c|c|c|c|}
\hline \multirow{3}{*}{$\begin{array}{l}\text { Ritue and ethnicity } \\
\text { and ses }\end{array}$} & \multicolumn{4}{|c|}{ Heme purchiase } & \multicolumn{4}{|c|}{ Relinana: } \\
\hline & \multirow{2}{*}{$\begin{array}{l}\text { Vumber } \\
\text { of } \\
\text { iqpplicutions }\end{array}$} & \multirow{2}{*}{$\begin{array}{l}\text { Tondjustiod } \\
\text { denial } \\
\text { ratis }\end{array}$} & \multicolumn{2}{|c|}{$\begin{array}{l}\text { Adjusted denial rate. } \\
\text { by adjustment lactis }\end{array}$} & \multirow{2}{*}{$\begin{array}{c}\text { Number } \\
\text { of } \\
\text { arpplications }\end{array}$} & \multirow{2}{*}{$\begin{array}{l}\text { Tnidjustad } \\
\text { denial } \\
\text { ralu: }\end{array}$} & \multicolumn{2}{|c|}{$\begin{array}{l}\text { Adjusted deuial rate, } \\
\text { by adjustmemt Pikisust }\end{array}$} \\
\hline & & & $\begin{array}{l}\text { Thenowwer- } \\
\text { related }\end{array}$ & $\begin{array}{l}\text { Borrower- } \\
\text { rolaud } \\
\text { plus leuder }\end{array}$ & & & $\begin{array}{l}\text { Borronwer- } \\
\text { related }\end{array}$ & $\begin{array}{l}\text { borrower- } \\
\text { rulaud } \\
\text { plus leuder }\end{array}$ \\
\hline \multicolumn{9}{|l|}{ Retre strai esharicity } \\
\hline Americau Indiau or Alaska _ative. & 4.785 & 57.3 & $55 \%$ & 52.7 & 1.670 & 58.6 & 57.9 & 51.5 \\
\hline Asiam ......................... & 1,736 & 44.4 & 44.1 & 41.2 & $6+1$ & 40.5 & 484 & 51.6 \\
\hline Hlack or African Americau ......... & 28,363 & 64.2 & 613.4 & $57 . \overline{7}$ & 9.535 & 63.9 & 61.6 & 53.8 \\
\hline \multicolumn{9}{|l|}{ Niatife Hatwatian es esher } \\
\hline Pacilic Tslander . ........... & $1, .51$ & 57.3 & 55.2 & 50.2 & 346 & 508 & 603 & 56.5 \\
\hline L'wo or more minority races .... & 121 & 686 & 63.5 & 74.7 & 73 & 56.2 & 68.4 & 50.2 \\
\hline I & 3.398 & 53.5 & 583 & 57.5 & 1.549 & 507 & 504 & 47.9 \\
\hline Race missing...$\ldots \ldots \ldots \ldots \ldots \ldots$. & 33,385 & (iili) & 58.4 & 54.7 & 39.337 & 64.2 & 68.5 & 52.7 \\
\hline Hispamic while ......... & 20,820 & 55.1 & 55.9 & 52.5 & 6.760 & 51.0 & 51.3 & 40.3 \\
\hline Non-llispanit white .... & 238,698 & 48.0 & 480 & 48.0 & 146,360 & 46.2 & 46.2 & 46.2 \\
\hline \multicolumn{9}{|l|}{ Sex } \\
\hline One malis... & 1011.964 & 52.7 & 52.7 & 52.7 & $54,2,94$ & 528 & 52.8 & 52.8 \\
\hline Oue female...... & 82.536 & $54 . i)$ & 52.3 & 52.1 & 39.726 & 53.7 & 53.1 & $52.9)$ \\
\hline I'wo males....... & $4.4 \times 3$ & 501.3 & 50.3 & 50.3 & 1.371 & 43.3 & 43,2 & 43.2 \\
\hline 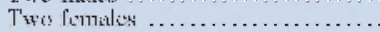 & 5,766 & 56.7 & 53.4 & 499 & 1.792 & 500 & 514 & 43.3 \\
\hline
\end{tabular}

NotE: See note to table 9.A. 
9. Unadjusted and adjusted denial rates on applications for loans on one- to four-family homes, by type of loan and by race and ethnicity and sex of applicant, 2004-Continued

E. Nonowner-occupied site-built home

Percent except as noted

\begin{tabular}{|c|c|c|c|c|c|c|c|c|c|c|c|c|}
\hline \multirow{4}{*}{$\begin{array}{l}\text { Ritis ind stmicity } \\
\text { and } s e x\end{array}$} & \multicolumn{8}{|c|}{ Conwntismal, lint lism } & \multirow{2}{*}{\multicolumn{4}{|c|}{ Other ${ }^{1}$}} \\
\hline & \multicolumn{4}{|c|}{ Hesme purchis: } & \multicolumn{4}{|c|}{ Relintunes } & & & & \\
\hline & \multirow[b]{2}{*}{$\begin{array}{l}\text { Number } \\
\text { of } \\
\text { utpplictlimnx }\end{array}$} & \multirow[b]{2}{*}{ 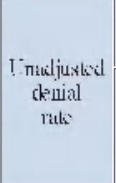 } & \multicolumn{2}{|c|}{ 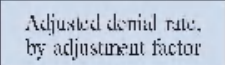 } & \multirow[b]{2}{*}{$\mid \begin{array}{c}\text { Yyumlx: } \\
\text { of } \\
\text { itpplicatiınx }\end{array}$} & \multirow[b]{2}{*}{$\begin{array}{l}\text { michljustud } \\
\text { denial } \\
\text { rats }\end{array}$} & \multicolumn{2}{|c|}{$\begin{array}{l}\text { Adjusted deniul rall, } \\
\text { by adjustment factor }\end{array}$} & \multirow[b]{2}{*}{$\begin{array}{c}\text { Yurratsir } \\
\text { of } \\
\text { urpylicaliunx }\end{array}$} & \multirow[b]{2}{*}{$\begin{array}{l}\text { ITnutjuliskisd } \\
\text { denial } \\
\text { rats: }\end{array}$} & \multicolumn{2}{|c|}{ 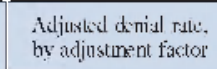 } \\
\hline & & & $\begin{array}{l}\text { Borrower- } \\
\text { nilited }\end{array}$ & $\begin{array}{c}\text { Busmower- } \\
\text { related } \\
\text { plus } \\
\text { lencker }\end{array}$ & & & $\begin{array}{l}\text { Borrowsel- } \\
\text { rislatid }\end{array}$ & $\begin{array}{l}\text { Thinvwer- } \\
\text { related } \\
\text { plux } \\
\text { lendkr }\end{array}$ & & & $\begin{array}{l}\text { Borrower- } \\
\text { nilisud }\end{array}$ & \begin{tabular}{|c} 
Bunvasur- \\
relaterd \\
plus \\
lendler
\end{tabular} \\
\hline \multicolumn{13}{|l|}{ Rares antil eshaticity } \\
\hline 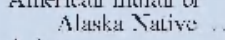 & 6881 & 37.5 & 28.5 & 162 & 5,674 & 30.5 & 30.5 & 270 & $2,18.3$ & 49.7 & 44.5 & 389 \\
\hline Asian ............... & 48,746 & 15.1 & 13.3 & 12.9 & 301317 & 20.4 & 22.3 & 22.2 & 6.716 & 300 & 32. 1 & 28.4 \\
\hline Americau .... & 80,1551 & 24.1 & 196 & 17.1 & 87.234 & 3016 & 28.6 & 25.4 & 26,017 & 44.8 & 38.4 & 34.1 \\
\hline 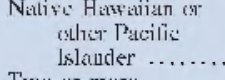 & $5,1.27$ & 18.2 & $15 \%$ & 13.3 & 4,401 & 24.8 & 25.2 & 26.4 & 1.611 & 41.5 & 33.7 & 32.4 \\
\hline $\begin{array}{l}\text { Twwo or more } \\
\text { miunity races. }\end{array}$ & & 14.8 & 13.1 & 10.8 & 661 & 24.4 & 28.3 & 306 & 214 & 43.1 & 33.5 & 46.2 \\
\hline$T_{\text {Tint }}$ & 11.839 & 11.1 & 13.4 & 12.6 & 7.057 & 18.1 & 230 & 30.1 & 2.202 & 24.7 & 31.9 & 27.5 \\
\hline Race missing .. & 123,995 & 18.2 & 17.2 & 14.2 & 132,928 & 32.5 & 30.9 & 26.2 & 31.499 & 40.3 & 37.6 & 31.5 \\
\hline Hispemic whice & 56012 & 18.7 & 140 & 14.2 & 44,640 & 26.8 & 24.4 & 22.7 & 14,508 & 370 & 349 & 318 \\
\hline Non-llispanic white & 650,022 & $11 . i$ & $11 . i$ & 11.6 & 484,333 & 17.8 & 17.8 & 17.8 & 133.098 & 25.5 & 25.5 & 25.5 \\
\hline Sex $x$ & & & & & & & & & & & & \\
\hline Oue male.. & 318,461 & 17.2 & 17.2 & 17.2 & 264.494 & 24.5 & 24.5 & 24.5 & 74,353 & 33.6 & 33.6 & 33.6 \\
\hline One fiemale & 164.107 & 17.5 & 163 & 163 & 143,972 & 25.5 & 24.0 & 33.8 & 43,267 & 39.3 & 34.6 & 336 \\
\hline I'wo males .......... & 25,564 & 101.7 & 10.7 & 10.7 & 13.387 & 16.2 & 16.2 & 16.2 & 4.006 & $24 . i$ & 24.0 & 24.0 \\
\hline Twos fempalis: ....... & 8.813 & 12.2 & 96 & 108 & 5,283 & 21.5 & 17.6 & 149 & 1,881 & 35.3 & 20.5 & 24.6 \\
\hline
\end{tabular}

lender almost always reduces differences further, although statistically significant differences remain between non-Hispanic whites and most of the other racial and ethnic groups.

For example, for conventional first-lien homepurchase loans, the unadjusted mean denial rate for blacks was 24.7 percent and for non-Hispanic whites 10.9 percent, a difference of 13.8 percentage points. Accounting for income, loan amount, and other borrower-related factors in the HMDA data reduces the difference 2.4 percentage points. Controlling for borrower-related factors plus lender significantly reduces the gap further, to 7.3 percentage points.

The reduction for conventional first-lien refinancing is even more dramatic. The unadjusted difference between black and non-Hispanic white denial rates is 17.6 percentage points, a difference cut by more than half, to 8.1 percentage points, when adjusted for borrower-related factors plus lender.

Differences in denial rates exhibit no consistent pattern with regard to the sex of the applicant. For some products, males have higher denial rates, and for others, females do; but in general, the size of the difference by sex is small. Furthermore, controlling for borrower-related factors plus lender has an inconsistent (but generally small) effect. In fact, in some cases adjustment reverses the sign of the differencethat is, for example, some denial rates that were higher for females than for males before adjustment become higher for males than for females after adjustment.

\section{Incidence of Higher-Priced Lending across Racial and Ethnic Groups}

Although most borrowers do not have higher-priced loans, the incidence of higher-priced lending varies substantially across racial and ethnic groups (table 10). Moreover, both the overall incidence of higher-priced lending and the differences across groups varies substantially across loan product categories. For government-backed loan products, small proportions of borrowers have higher-priced loans, and no meaningful differences appear across racial and ethnic groups. At the other extreme, the majority of borrowers for manufactured homes have higherpriced loans; and for this product, significant differences appear across racial and ethnic groups (although these differences are smaller than for some other products).

Differences in the incidence of higher-priced lending across loan products make it difficult to identify 
10. Unadjusted and adjusted incidence of higher-priced lending for loans on one- to four-family homes, by type of loan and by race and ethnicity and sex of borrower, 2004

A. Home purchase, owner-occupied site-built home

Percent except as noted

\begin{tabular}{|c|c|c|c|c|c|c|c|c|c|c|c|c|}
\hline \multirow{4}{*}{$\begin{array}{l}\text { Ritis and shlmicity } \\
\text { and sex }\end{array}$} & \multicolumn{8}{|c|}{ Cumbatismal } & \multirow{2}{*}{\multicolumn{4}{|c|}{ Government backed. tirst lien }} \\
\hline & \multicolumn{4}{|c|}{ Tïrst lien } & \multicolumn{4}{|c|}{ Juniun lisn } & & & & \\
\hline & \multirow[b]{2}{*}{$\begin{array}{c}\text { Rumber } \\
\text { of } \\
\text { lixmx }\end{array}$} & \multirow[b]{2}{*}{$\begin{array}{l}\text { T'midjuxlsil } \\
\text { imcickence }\end{array}$} & \multicolumn{2}{|c|}{$\begin{array}{l}\text { Adjusted incidence. } \\
\text { by adjostunent factor }\end{array}$} & \multirow[b]{2}{*}{$\begin{array}{c}\text { Yumbir } \\
\text { of } \\
\text { listmx }\end{array}$} & \multirow[b]{2}{*}{$\begin{array}{l}\text { mitjusted } \\
\text { incickence }\end{array}$} & \multicolumn{2}{|c|}{$\begin{array}{l}\text { idjusled incidnce. } \\
\text { by adjustnent factor }\end{array}$} & \multirow[b]{2}{*}{$\begin{array}{c}\text { Vumber } \\
\text { of } \\
\text { lixinx }\end{array}$} & \multirow[b]{2}{*}{$\begin{array}{c}\text { ITntaljuxtsid } \\
\text { incidence }\end{array}$} & \multicolumn{2}{|c|}{$\begin{array}{l}\text { Rodjuxted incidens: } \\
\text { by adjustunent factor }\end{array}$} \\
\hline & & & $\begin{array}{l}\text { Borrower- } \\
\text { nililied }\end{array}$ & $\begin{array}{c}\text { Bistower- } \\
\text { related } \\
\text { plus } \\
\text { lencker }\end{array}$ & & & $\begin{array}{l}\text { Borrowel- } \\
\text { wlitiod }\end{array}$ & $\begin{array}{l}\text { Tsinvower- } \\
\text { related } \\
\text { plux } \\
\text { lencker }\end{array}$ & & & $\begin{array}{l}\text { Borrower- } \\
\text { nilised }\end{array}$ & $\begin{array}{l}\text { Buncswer- } \\
\text { related } \\
\text { plus } \\
\text { lender }\end{array}$ \\
\hline \multicolumn{13}{|l|}{ Rate atal eshatic ify } \\
\hline $\begin{array}{l}\text { Americau Indian or } \\
\text { Alaska Natiw ... }\end{array}$ & 28,1017 & 18.1 & 17.2 & 11.8 & 7,618 & 50.2 & $47 . .5$ & 33.6 & 4.751 & 4.9 & 4.1 & 1.1 \\
\hline $\begin{array}{l}\text { Asian ................ } \\
\text { Black ir Alitioum }\end{array}$ & 196.359 & 5)$. & 7.4 & 8.1 & 32.444 & 34.4 & 30.8 & 20.9 & 5.412 & 2.5 & 1.7 & .8 \\
\hline Americau ...... & 232.688 & 32.4 & 26.7 & 15.7 & 62,434 & 61.9 & 58.3 & 37.1 & 50,275 & 1.5 & 1.3 & 1.1 \\
\hline 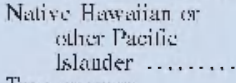 & 201.203 & 15.7 & 16.3 & 11.1 & 6,195 & 496 & 44.9 & 33.5 & 2.373 & 3.3 & 1.6 & 1.4 \\
\hline 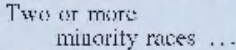 & 2.613 & 22.9 & 23.2 & 12.2 & 6i) 9 & 43.2 & 44.3 & 26.6 & 4iii & 20.5 & 17.0 & 1.2 \\
\hline Tivint & 47,209 & 69 & 10.8 & 9.4 & 9,000 & 29.3 & 36.7 & 31.2 & 10,035 & 1.1 & 1.1 & 1.4 \\
\hline Race missing ......... & 3901.136 & 13.4 & 16.8 & 11.1 & $9(1,1+1 j$ & 40.7 & 43.5 & 33.2 & 35.547 & 1.4 & 1.3 & i) \\
\hline Hispanic white & 301.915 & 201.2 & 166 & 11.6 & 87,612 & 580 & 499 & 35.1 & 47,055 & 2.1 & 1.1 & 1.1 \\
\hline Non-llispanis: white .. & $2,476.255$ & 8.7 & 8.7 & 8.7 & 394,357 & 301.4 & 30.4 & 301.4 & $3(4.8(i)$ & 1.1 & 1.1 & 1.1 \\
\hline \multicolumn{13}{|l|}{ Sic $x$} \\
\hline Oue male ....... & 1.129 .781 & 15.3 & 15.3 & 15.3 & 237.097 & 46.1 & 46.1 & 40.1 & 145.375 & 1.3 & 1.3 & 1.3 \\
\hline One fimale & 850,213 & $15 \ldots$ & 14.4 & 15.0 & 162,680 & 47.8 & 45.9 & 46.7 & 98,428 & 1.6 & 1.5 & 1.3 \\
\hline Iwo males .......... & 38.170 & 9.5 & 9.5 & 9.5 & 7.879 & 34.4 & 34.4 & 34.4 & $10,0 j 44$ & 1.2 & 1.2 & 1.2 \\
\hline 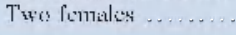 & 31,0183 & 10.4 & 90 & 9.8 & 6,064 & 37.2 & 34.5 & 35.2 & 6,716 & 1.2 & 1.3 & 1.1 \\
\hline
\end{tabular}

NoTE: Excludes transition-period loans (those for which the application was submitted before 2004). For definition of higher-priced lending and explanation of adjustment factors, see text. For method of allocation into racial and

ethnic categories and definitions of categories, see general note to table 6

and text note 35 . Loans taken out jointly by a male ond temale are not tabulated

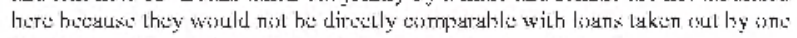

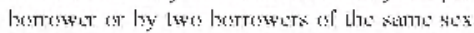

10.-Continued

B. Refinance, owner-occupied site-built home

Percent except as noted

\begin{tabular}{|c|c|c|c|c|c|c|c|c|c|c|c|c|}
\hline \multirow{4}{*}{$\begin{array}{l}\text { Ritus ind stmicity } \\
\text { and sex }\end{array}$} & \multicolumn{8}{|c|}{ Comwentismal } & \multirow{2}{*}{\multicolumn{4}{|c|}{ Governnent backed, first lien }} \\
\hline & \multicolumn{4}{|c|}{ First lien } & \multicolumn{4}{|c|}{ Juniar lien } & & & & \\
\hline & \multirow[b]{2}{*}{$\begin{array}{l}\text { Number } \\
\text { of } \\
\text { lixums }\end{array}$} & \multirow[b]{2}{*}{$\begin{array}{c}\text { T-nualjuxtsid } \\
\text { incididnee }\end{array}$} & \multicolumn{2}{|c|}{$\begin{array}{l}\text { Adjusted incidence. } \\
\text { by adjustunent fiactor }\end{array}$} & \multirow[b]{2}{*}{$\begin{array}{c}\text { Sumber } \\
\text { of } \\
\text { listunx }\end{array}$} & \multirow[b]{2}{*}{$\begin{array}{l}\text { madjuxted } \\
\text { incidinae }\end{array}$} & \multicolumn{2}{|c|}{$\begin{array}{l}\text { Adjusted incidince, } \\
\text { by acliustnent fiactor }\end{array}$} & \multirow[b]{2}{*}{$\begin{array}{l}\text { Yumber } \\
\text { of } \\
\text { lixins }\end{array}$} & \multirow[b]{2}{*}{$\begin{array}{l}\text { Tinuiljustidal } \\
\text { incidines }\end{array}$} & \multicolumn{2}{|c|}{$\begin{array}{l}\text { Aljustud incidenes, } \\
\text { by adjustunent factor }\end{array}$} \\
\hline & & & $\begin{array}{c}\text { Borrower- } \\
\text { ielated }\end{array}$ & $\begin{array}{l}\text { Bomber- } \\
\text { Irlated } \\
\text { plus } \\
\text { lindst }\end{array}$ & & & $\begin{array}{l}\text { Borrower- } \\
\text { related }\end{array}$ & $\begin{array}{l}\text { Th:nimbur- } \\
\text { related } \\
\text { plus } \\
\text { linds }\end{array}$ & & & $\begin{array}{l}\text { Borrower- } \\
\text { related }\end{array}$ & $\begin{array}{c}\text { Bunvswer- } \\
\text { related } \\
\text { plus } \\
\text { lender }\end{array}$ \\
\hline \multicolumn{13}{|l|}{$\begin{array}{l}\text { Rare atrid whaticity } \\
\text { American Indian or }\end{array}$} \\
\hline $\begin{array}{c}\text { Alaska .alive } \\
\text { Alite }\end{array}$ & 44,5013 & 30.2 & 210 & 14.7 & 2.981 & 26.8 & 24.4 & 26.1 & 2,216 & 4.4 & 4.2 & 10 \\
\hline Asian ............. & 317.114 & 5)$. & 9.7 & 13.1 & 10.519 & 35.4 & 24.) & 24.3 & 3.348 & 3.6 & 2.0 & 1.0 \\
\hline $\begin{array}{l}\text { Eilack of African } \\
\text { Anzerican ..... }\end{array}$ & 391.524 & 34.6 & 20.5 & 17.6 & 24,292 & 45.2 & 41.3 & 26.4 & 46,603 & 1.0 & 1.2 & 1.5 \\
\hline $\begin{array}{l}\text { Native Ilawaiiau or } \\
\text { shlis Pacilis }\end{array}$ & & & & & & & & & & & & \\
\hline $\begin{array}{l}\text { Islauder } \\
\text { Twyo or mari: }\end{array}$ & 31.381 & 16.4 & 186 & 14.5 & 2,367 & 35.8 & 33.2 & 24.6 & 1.547 & 6.1 & 4.1 & 1.4 \\
\hline $\begin{array}{l}\text { miuority races } \\
\text { ming }\end{array}$ & 5.189 & 21.1 & 23.4 & $15 . i$ & 394 & Li). 3 & 25.4 & 24.7 & 347 & 18.7 & 19.6 & 2.3 \\
\hline Toint ............. & 67.100 & 11.4 & 14.7 & 1.3 .5 & 5609 & 23.3 & 36.5 & 24.8 & 6,101 & 9 & 1.1 & 1.2 \\
\hline Race missing .. & 827.5010 & 19.3 & 25.4 & 15.3 & 82,329 & 32.7 & 42.1 & $2+.8$ & 31,6013 & 2.15 & 3.0 & 1.3 \\
\hline llispanit white & 378.826 & 19.3 & 18.5 & 14.3 & 30.687 & 35.1 & 28.7 & 25.2 & 31.814 & 1.9 & 1.2 & 1.4 \\
\hline Nen-Hispanic whice & $3,698,309$ & 129 & 129 & 12.9 & 285.5015 & 230 & 320 & 230 & 152,619 & 1.3 & 1.3 & 1.3 \\
\hline \multicolumn{13}{|l|}{ Sic $x$} \\
\hline Oue male. & $1,3601,350$ & 18.6 & 186 & 18.6 & 90,691 & 34.01 & 34.11 & 34 & 63.536 & 1.4 & 1.4 & 1.4 \\
\hline One fimale: & $1,173,835$ & 19.8 & 18.5 & 18.7 & 67,266 & 32.6 & 32.6 & 339 & 40.282 & 1.7 & 1.6 & 1.4 \\
\hline L'wo males ..... & 401012 & 12.1 & 13.1 & 13.1 & $3 ., 024$ & 23.6 & 236 & 23.6 & 3.103 & 3.2 & 2.2 & 2.2 \\
\hline Two femalles ..... & 43,2018 & 17.3 & 14.5 & 13.4 & 2,887 & 31.7 & 36.6 & 22.6 & 3,053 & 1.8 & 1.5 & 1.6 \\
\hline
\end{tabular}

NoTE: See note to table 10.A. 
10. Unadjusted and adjusted incidence of higher-priced lending for loans on one- to four-family homes. by type of loan and by race and ethnicity and sex of borrower, 2004-Continued

C. Home improvement, conventional loan, owner-occupied site-built home Percent except as noted

\begin{tabular}{|c|c|c|c|c|c|c|c|c|}
\hline \multirow{3}{*}{$\begin{array}{l}\text { Rive and ethmicity } \\
\text { and sex }\end{array}$} & \multicolumn{4}{|c|}{ Гंirst licn } & \multicolumn{4}{|c|}{ Junis lien } \\
\hline & \multirow{2}{*}{$\begin{array}{l}\text { Number } \\
\text { of } \\
\text { loans }\end{array}$} & \multirow{2}{*}{$\begin{array}{l}\text { Lnadjusted } \\
\text { incidence }\end{array}$} & \multicolumn{2}{|c|}{$\begin{array}{l}\text { Adjusted incideuce, } \\
\text { by adjustment tautol }\end{array}$} & \multirow{2}{*}{$\begin{array}{c}\text { Number } \\
\text { loil } \\
\text { loans }\end{array}$} & \multirow{2}{*}{$\begin{array}{l}\text { IInadjusted } \\
\text { incidience }\end{array}$} & \multicolumn{2}{|c|}{$\begin{array}{l}\text { Adjusted incideuce, } \\
\text { by adjustmeut tactor }\end{array}$} \\
\hline & & & $\begin{array}{l}\text { Thenowiver- } \\
\text { related }\end{array}$ & $\begin{array}{l}\text { Thorronfer- } \\
\text { related } \\
\text { plus: limdir }\end{array}$ & & & $\begin{array}{l}\text { Bomrous:t- } \\
\text { related }\end{array}$ & 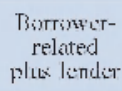 \\
\hline \multicolumn{9}{|l|}{ Rare atrib ethaticity } \\
\hline Americau Indian or Alaska_lative .. & 3.775 & 23.4 & 25.8 & 22.5 & 2.628 & 18.8 & 17.4 & 17.5 \\
\hline 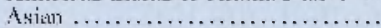 & 8007 & 8.4 & 163 & 18.8 & 6,467 & 13.5 & 15.1 & 16.6 \\
\hline Black ar Alician American . . . . & 27,677 & 42.5 & 39.2 & 24.6 & 19.520 & 37.9 & 31.3 & 180 \\
\hline \multicolumn{9}{|l|}{ Native llawaiiau or other } \\
\hline Pacilic Islander a. . . . . & 2,237 & 17.7 & 22.4 & 21.9 & 1.749 & 26.5 & 22.6 & 169 \\
\hline I'wo or more minority races ... & 341 & 22.3 & 23.6 & 18.6 & 193 & 16.6 & 15.1 & 14.1 \\
\hline I $_{\text {vint }} \ldots \ldots \ldots \ldots \ldots \ldots \ldots \ldots \ldots \ldots \ldots \ldots \ldots \ldots \ldots$ & 3.894 & 15.5 & 20.7 & 19.2 & 5.2801 & 15.2 & 18.3 & 16.3 \\
\hline Race missing $\ldots \ldots \ldots \ldots \ldots \ldots \ldots$. & 36,877 & 21.5 & $32-3$ & 21.4 & 61. .ji15 & 17.4 & 23.1 & 15.9 \\
\hline Hispramic white & 28.305 & 26.7 & 27.6 & 210 & $1.5,464$ & 210 & 2010 & 16.5 \\
\hline Non-llispanit white .... & 221.213 & 19.5 & 19.5 & 19.5 & 259.771 & 15.6 & 15.6 & 15.6 \\
\hline \multicolumn{9}{|l|}{ Sex } \\
\hline Oue male ...... & 74,062 & 26.1 & 26.1 & 26.1 & 71.519 & 24.4 & 34.4 & 24.4 \\
\hline Oni fimale $\ldots \ldots$ & 74.479 & 27,9 & 25.8 & 26.5 & 57,771 & 22,3 & 21.4 & 23.6 \\
\hline I'wo males ........................ & 3.545 & 17.2 & 17.3 & 17.2 & 3.390 & 19.1 & 19.1 & 19.1 \\
\hline Tưo fumalis & 3.053 & 230 & 18.5 & 21.2 & 2,8017 & 100 & 18.1 & 102 \\
\hline
\end{tabular}

Note: See note to table $10 . \mathrm{A}$.

10.-Continued

D. Manufactured housing, conventional loan, first lien, owner-occupied home

Percent except as noted

\begin{tabular}{|c|c|c|c|c|c|c|c|c|}
\hline \multirow{3}{*}{$\begin{array}{l}\text { Rives and ethmicity } \\
\text { and ses }\end{array}$} & \multicolumn{4}{|c|}{ Heme purchiasio } & \multicolumn{4}{|c|}{ R:linani: } \\
\hline & \multirow{2}{*}{$\begin{array}{l}\text { Yumber } \\
\text { of } \\
\text { listans }\end{array}$} & \multirow{2}{*}{$\begin{array}{l}\text { Lnadjusted } \\
\text { incidines }\end{array}$} & \multicolumn{2}{|c|}{$\begin{array}{l}\text { Adjusted incidence, } \\
\text { by udjustment Puctior }\end{array}$} & \multirow{2}{*}{$\begin{array}{c}\text { Number } \\
\text { of } \\
\text { lisams }\end{array}$} & \multirow{2}{*}{$\begin{array}{l}\text { Wuadiusted } \\
\text { incidenco: }\end{array}$} & \multicolumn{2}{|c|}{$\begin{array}{l}\text { Adjusted incideuce, } \\
\text { by adjuximeint liatus }\end{array}$} \\
\hline & & & $\begin{array}{l}\text { Thonowar- } \\
\text { related }\end{array}$ & $\begin{array}{l}\text { Borrower- } \\
\text { rolaud } \\
\text { plus leuder }\end{array}$ & & & $\begin{array}{l}\text { Berrompict- } \\
\text { related }\end{array}$ & $\begin{array}{l}\text { Eiorrower- } \\
\text { roluhud } \\
\text { plus leuder }\end{array}$ \\
\hline \multicolumn{9}{|l|}{ Rat'e strol eshorisity } \\
\hline American Indiau or Alaska Vative. & 1.168 & 68.2 & 58.3 & 54.8 & 513 & 51.9 & 53.5 & 506 \\
\hline 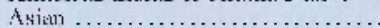 & 537 & 62.8 & 62.6 & 61.9 & 210 & 42.9 & 478 & 560 \\
\hline Hlack or African Americau ........ & 5.175 & 78.5 & 64.8 & (ii) & 2.316 & 67.7 & 56.1 & 50.1 \\
\hline Pacilic Tolander ........... & 315 & 70.8 & 69.2 & 65.2 & 102 & 480 & 44.5 & 45.5 \\
\hline I'wo or more minority races..... & 21 & 47.6 & 51.2 & 57.0 & 26 & 43.3 & 54.3 & -3.8 \\
\hline I & 918 & $58 \ldots 3$ & 568 & 601.2 & 568 & 41.2 & 40.3 & 48.7 \\
\hline Race missing $\ldots \ldots \ldots \ldots \ldots$ & 6.535 & 57.2 & 56.6 & 55.4 & 7.420 & 50.0 & 51.6 & 46.3 \\
\hline Hispamic while ......... & 5.598 & 67.5 & 65.2 & 60.7 & 2.274 & 46.2 & 56.7 & 500 \\
\hline Non-llispanit white ......... & 76,324 & 54.7 & 54.7 & 54.7 & 56,713 & 46.6 & 46.6 & $46 i$ \\
\hline \multicolumn{9}{|l|}{ Setix } \\
\hline$O_{n i}$ mali $\ldots \ldots \ldots$ & 28,10101 & 61.0 & 61.0 & 61.0 & 17.181 & 486 & 48.6 & 48.6 \\
\hline Oue temale ............ & 23.177 & 60.5 & $61 j .2$ & 50.8 & 12.773 & 49.8 & 49.0 & 40.2 \\
\hline Iwo males ...................... & 1.506 & 65.1 & 65.1 & 65.1 & 5010 & 56.3 & 56.3 & $56 . \overline{3}$ \\
\hline Twwo femialis ................... & 1.547 & 650 & 64.6 & 65.1 & 622 & 47.3 & 508 & 536 \\
\hline
\end{tabular}

Note: See note to table 10.A. 
10. Unadjusted and adjusted incidence of higher-priced lending for loans on one- to four-family homes, by type of loan and by race and ethnicity and sex of borrower, 2004-Continued

E. Nonowner-occupied site-built home

Percent except as noted

\begin{tabular}{|c|c|c|c|c|c|c|c|c|c|c|c|c|}
\hline \multirow{4}{*}{$\begin{array}{l}\text { Riws and slmicity } \\
\text { and } s e x\end{array}$} & \multicolumn{8}{|c|}{ Conwntismal, linst lisn } & \multirow{2}{*}{\multicolumn{4}{|c|}{ Other ${ }^{1}$}} \\
\hline & \multicolumn{4}{|c|}{ Hsame purchas: } & \multicolumn{4}{|c|}{ Retimanee } & & & & \\
\hline & \multirow[b]{2}{*}{$\begin{array}{l}\text { Number } \\
\text { of } \\
\text { lixums }\end{array}$} & \multirow[b]{2}{*}{$\begin{array}{l}\text { T. muldjuxkid } \\
\text { incictence }\end{array}$} & \multicolumn{2}{|c|}{$\begin{array}{l}\text { Adjusked incidence, } \\
\text { by adjustunent fiactor }\end{array}$} & \multirow[b]{2}{*}{$\begin{array}{l}\text { Yumber } \\
\text { of } \\
\text { lsanx }\end{array}$} & \multirow[b]{2}{*}{$\begin{array}{l}\text { madjuxited } \\
\text { incickence }\end{array}$} & \multicolumn{2}{|c|}{$\begin{array}{l}\text { Adjustud incidnce. } \\
\text { by acliustment factor }\end{array}$} & \multirow[b]{2}{*}{$\begin{array}{l}\text { Sumber } \\
\text { of } \\
\text { lisenns }\end{array}$} & \multirow[b]{2}{*}{$\begin{array}{l}\text { ITntaljuxlid } \\
\text { inciclence }\end{array}$} & \multicolumn{2}{|c|}{$\begin{array}{l}\text { Rajjustud incidencs, } \\
\text { by adjustunent factor }\end{array}$} \\
\hline & & & $\begin{array}{c}\text { Borrower- } \\
\text { nilitled }\end{array}$ & \begin{tabular}{|c|} 
BS:minuser- \\
relatedl \\
plus \\
lender
\end{tabular} & & & $\begin{array}{l}\text { Borrower- } \\
\text { rslatid }\end{array}$ & $\begin{array}{l}\text { Th:nuwer- } \\
\text { related } \\
\text { plus } \\
\text { lenckr }\end{array}$ & & & $\begin{array}{l}\text { Borrower- } \\
\text { nilited }\end{array}$ & \begin{tabular}{|c|} 
Buntwaser- \\
relaterd \\
plus \\
lendler
\end{tabular} \\
\hline \multicolumn{13}{|l|}{ Reres and whaticity } \\
\hline 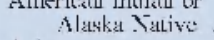 & 3.576 & 169 & 15.6 & 11.1 & 3,166 & 19.7 & 21.5 & 14.1 & 828 & 34.8 & 25.2 & 31.2 \\
\hline Asian ............... & $33,5 i 2$ & 7.4 & 8.5 & 8.6 & 18.8019 & 7.0 & 10.9 & 11.3 & 3.785 & 37.5 & 33.1. & 310.4 \\
\hline 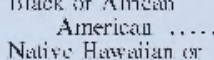 & 46,2601 & 38.6 & 24.2 & 14.7 & $46,6 i i j$ & 33.5 & 27.7 & 16.7 & $11,(09)$ & 46.8 & 43.2 & 33.6 \\
\hline 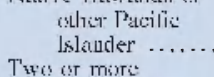 & $3,4 j 7$ & 15.8 & 146 & 11.2 & 2.6616 & 14.6 & 17.3 & $13 . i$ & 731 & 42.8 & 33.5 & 29.5 \\
\hline $\begin{array}{l}\text { Twes or mire } \\
\text { miustity races }\end{array}$ & 424 & 25.7 & 23.5 & 11.4 & 424 & 24.8 & 27.5 & $159)$ & 97 & 38.1 & 19.9 & 55.4 \\
\hline Toint & 8.571 & 7.1 & 110 & 0.7 & 5,421 & 8.2 & 13.5 & 11.2 & 1.466 & 27.2 & 31.8 & 286 \\
\hline Rave missing.. & 76.434 & 11.5 & 14.1 & 10.6 & $6+341$ & 15.5 & 22.2 & 13.5 & 13.877 & 41.1 & $4 j 0$ & 33.6 \\
\hline Hispamic while: & 40,643 & 16.8 & 15.4 & 100 & 28,011 & 170 & 18.1 & 13.3 & 7.522 & $\begin{array}{l}+1.1 \\
4 \% .4\end{array}$ & 40.1 & 3.5 \\
\hline Non-llispanis white & 502030 & 9.4 & 9.4 & 9.4 & 3301979 & 10.9 & 10.19 & 1009 & $81,+18$ & 30.2 & 310.2 & 30.2 \\
\hline \multicolumn{13}{|l|}{$\operatorname{sic} x$} \\
\hline Oue male.. & 219,7001 & 17.7 & 17.7 & 17.7 & 161.011 & 17.9 & 17.9 & 17.) & 3i) 283 & 43.5 & 43.5 & 43.5 \\
\hline One fismale: & 111,338 & 17.4 & 169 & 160 & 85,278 & 19.8 & 19.8 & 18.4 & 20,416 & 430 & 42.5 & 4.1 \\
\hline I'wo males ....... & 19,437 & 8.3 & 83 & 8.3 & 9) 103 & 7.9 & 7.9 & 7.9 & 2.526 & 27.2 & 27.2 & 27.2 \\
\hline Twyo fumpialis....... & 6428 & 7.6 & 68 & 70 & 3,307 & 12.0 & 03 & 10.2 & 984 & 356 & 33.5 & 320 \\
\hline
\end{tabular}

NoTE: See note to table $10 . \mathrm{A}$

1. "Other" consists of government-hacked loans of all types, junior" liens,

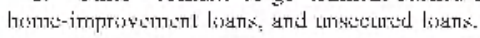

consistent patterns across all types of lending. Conventional home-purchase lending and conventional refinance lending include most of the borrowers covered by the HMDA data, and consequently those loan types are the main focus of the discussion of higherpriced lending that follows. In general, unadjusted differences in the incidence of higher-priced lending between non-Hispanic whites, on the one hand, and blacks, on the other, are large, but these differences are substantially reduced after controlling for borrower-related factors plus lender.

Most of the reduction in the difference in the incidence of higher-priced lending across groups comes from adding the control for lender to the control for borrower-related factors. For conventional first-lien home-purchase loans, the mean unadjusted incidence of higher-priced lending was 32.4 percent for blacks and 8.7 percent for non-Hispanic whites, a difference of 23.7 percentage points. Borrowerrelated factors account for about one-fourth of the difference. Adding to this adjustment the control for lender reduces the remaining gap markedly, to 7 percentage points. For conventional first-lien refinancings, the unadjusted difference between blacks and non-Hispanic whites is 21.7 percentage points; this difference is reduced to 4.7 percentage points after controlling borrower-related factors plus lender, and about two-thirds of that reduction comes from the addition of the control for lender. Similar patterns for differences between black and non-Hispanic white borrowers are found for the junior-lien products.

The picture for Asians differs greatly from that for blacks. Asians have a lower unadjusted mean incidence of higher-priced lending for first-lien conventional home-purchase and refinance loans than do non-Hispanic whites. The gap is narrowed by controlling for borrower-related factors plus lender, although the incidence of higher-priced lending remains lower for Asians than for non-Hispanic whites. Hispanic whites show a pattern similar to that of blacks, but with smaller differences relative to non-Hispanic whites. For first-lien conventional loan products, the adjusted differences for Hispanic whites are less than one-half those for blacks; for conventional homepurchase junior liens, the differences for Hispanic whites are close to those for blacks.

The foregoing analysis indicates that the information in the HMDA data- that is, adjusting the HMDA data for borrower-related factors plus lender-is insufficient to account fully for racial or ethnic differences in the incidence of higher-priced lending; significant differences remain unexplained. Explaining 
11. Unadjusted and adjusted incidence of higher-priced lending for conventional, first-lien loans on site-built. owner-occupied, one- to four-family homes, by selected race and ethnicity for selected characteristics of borrower; property, and lender, 2004

Percent except as noted

\begin{tabular}{|c|c|c|c|c|c|c|c|c|}
\hline \multirow{3}{*}{$\begin{array}{l}\text { Selected tharacteristic, } \\
\text { by rawe and ethnicily of bencewer }\end{array}$} & \multicolumn{4}{|c|}{ Home purchase } & \multicolumn{4}{|c|}{ Retinauce } \\
\hline & \multirow{2}{*}{$\begin{array}{l}\text { Yumber } \\
\text { of } \\
\text { livans: }\end{array}$} & \multirow{2}{*}{$\begin{array}{l}\text { Tharljusted } \\
\text { incidenee }\end{array}$} & \multicolumn{2}{|c|}{$\begin{array}{l}\text { Adjusted incideuce, } \\
\text { by adjustment Factior }\end{array}$} & \multirow{2}{*}{$\begin{array}{c}\text { Number } \\
\text { of } \\
\text { lesans: }\end{array}$} & \multirow{2}{*}{$\begin{array}{l}\text { TTnadjustud } \\
\text { incidence: }\end{array}$} & \multicolumn{2}{|c|}{ 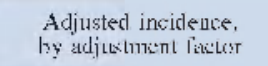 } \\
\hline & & & $\begin{array}{l}\text { Bormwer- } \\
\text { related }\end{array}$ & $\begin{array}{l}\text { Borrower- } \\
\text { relaud } \\
\text { plus leuder }\end{array}$ & & & $\begin{array}{l}\text { Borrower- } \\
\text { related }\end{array}$ & $\begin{array}{l}\text { biorrower- } \\
\text { rolaud } \\
\text { plus leucler }\end{array}$ \\
\hline \multicolumn{9}{|l|}{ INCOMF OF T3ORROWFR } \\
\hline \multicolumn{9}{|l|}{ Lower } \\
\hline Tlack is Africian American & $87,8+1$ & 39.2 & 35.2 & 21.7 & 161.762 & 42.1 & 396 & 259 \\
\hline Ilispanit white .................. & $83.6+2$ & 236 & 21.2 & 16.3 & 1.20 .253 & 22.5 & 34.2 & 30.4 \\
\hline Non-llispanic white ............ & 637,019 & 12.9 & 12.9 & 12.) & 961.571 & 19.3 & 19.3 & 19.3 \\
\hline \multicolumn{9}{|l|}{ Widale: } \\
\hline Tlack or Afician American & 66.997 & 339 & 31.1 & 18.1 & 112.0177 & 34.8 & 33.8 & 20.1 \\
\hline Ilispanit: white .............. & 84,958 & 22.1 & 19.5 & 13.3 & $1.18,696$ & 20.8 & 21.5 & 16,6 \\
\hline Nem-Hispanic white :... & 648,85 & 90 & 00 & 99 & 989.420 & 140 & 149 & 140 \\
\hline \multicolumn{9}{|l|}{ Higher } \\
\hline bilack or African Americau & 70.247 & 23.) & 19.8 & 10.9 & 104,662 & 26.15 & 22.8 & 12.7 \\
\hline 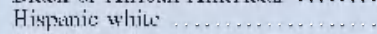 & 118.728 & 17.4 & 12.5 & 7.8 & 123,101 & 169 & 146 & 10.4 \\
\hline Nen-Hispamic whice & $10,190.544$ & 5.8 & 5.8 & 5.8 & 1.539 .336 & 90 & 900 & 90 \\
\hline \multicolumn{9}{|l|}{ IACOME OF CFNSTS TRACT } \\
\hline \multicolumn{9}{|l|}{ Loher } \\
\hline Tlack or A frician Amurican & 60.713 & 419 & 34.7 & 22.7 & 141.851 & 42.5 & 37.5 & 27.4 \\
\hline Hispanic while & 85.791 & 260 & 250 & 18.8 & 126.577 & 23.3 & 256 & 22.9 \\
\hline Non-llispanit white . & 254.231 & 150 & 150 & 150 & 383,904 & 21.7 & 31.7 & 21.7 \\
\hline \multicolumn{9}{|l|}{ Widale: } \\
\hline Black or A Arician American & 107,177 & 320 & 200 & 17.8 & 175,784 & 334 & 31.2 & 19.5 \\
\hline llispanit: white ............ & 137.291 & 20.5 & 17.7 & 130 & 167.456 & 19.2 & 19.6 & 16,0 \\
\hline Nom-Hispanic whice & $1.229,890$ & 10.2 & 103 & 10.3 & $1.936 .16 \mathrm{i}$ & 150 & 150 & 150 \\
\hline \multicolumn{9}{|l|}{ Wighor } \\
\hline bilatk or African Americau . & 55.401 & 22.7 & 18.2 & 9.8 & 73.571 & 23.2 & 18.1 & 10.2 \\
\hline Ilispanit: white .............. & $7 n, 431$ & 13,6 & 16.5 & 7.01 & $84,1,51$ & 13.6 & 11.7 & B.. \\
\hline Non-Ilispanic white .......... & 984.982 & 5.2 & 5.3 & 5.2 & $1.3701,653$ & 7.4 & 7.4 & 7.4 \\
\hline \multicolumn{9}{|l|}{ CRA ASSLSSWUVI ARLA } \\
\hline \multirow{2}{*}{\multicolumn{9}{|c|}{ 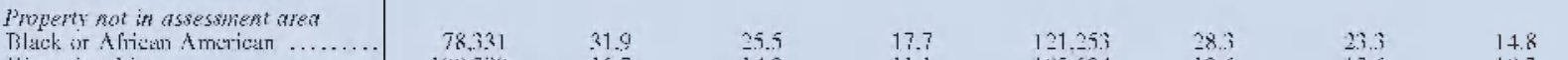 }} \\
\hline & 78,331 & 31.9 & 25.5 & 17.7 & 121,253 & 283 & 233 & 14.8 \\
\hline Ilispanit: white ..................... & 1001.296 & 16.7 & 14.3 & 11.1 & 105,634 & 13.6 & 1.2 .6 & 10.3 \\
\hline Nem-Hispanic whice . ............... & $1,010,824$ & 7.4 & 7.4 & 7.4 & $1.419,602$ & 8.8 & 8.8 & 8.8 \\
\hline \multicolumn{9}{|l|}{ Property in assersment arra } \\
\hline Black or African Americau & 43.680 & 12.7 & 9.99 & 6.6 & $79,+133$ & 13.3 & 10.9 & 6.4 \\
\hline $\begin{array}{l}\text { Hitprunic while } \\
\text { Non-Ilispanic white . . . . . . }\end{array}$ & $\begin{array}{r}68,101 \\
6101870\end{array}$ & 9.6 & $\begin{array}{l}5.6 \\
1.8\end{array}$ & $\begin{array}{l}4 . ! \\
2.8\end{array}$ & $\begin{array}{l}113,714 \\
0,164,166\end{array}$ & $\begin{array}{l}7.7 \\
3.9\end{array}$ & $\begin{array}{l}5.3 \\
3.0\end{array}$ & $\begin{array}{l}4.6 \\
3.9\end{array}$ \\
\hline & & & & & & & & \\
\hline
\end{tabular}

Notes appear at end of table.

the remaining differences is likely to require more details about such factors as the specific credit circumstances of each borrower, the specific loan products they seek, and the business practices of the institutions they approach for credit.

Understanding the patterns within the HMDA data is also likely to require more information. Two somewhat offsetting patterns are shown in the data. On the one hand, minority borrowers (except for Asians) tend to disproportionately use government-backed products, which show a much lower incidence of higher-priced loans. The implication is that the difference in the incidence of higher-priced lending between minorities and non-Hispanic whites is lower for the combined loan product, conventional and government-backed loans, than for each product separately. On the other hand, for a given loan type, whether government-backed or conventional, nonAsian minorities tend to disproportionately borrow from lenders that have higher incidences of higherpriced loans, a tendency on the part of minority borrowers that accounts for much of the aggregate difference in outcomes between them and nonHispanic white borrowers.

The disproportionate borrowing by non-Asian minorities from higher-priced lenders could occur because of often benign factors such as a "segmented" marketplace in which different lenders offer different products and borrower groups self-select the product-lender combination that best matches their credit or other circumstances. Such a marketplace does not necessarily raise public-policy concerns regarding fair lending: For example, compared with non-Hispanic whites, minority groups on average 
11.-Continued

Percent except as noted

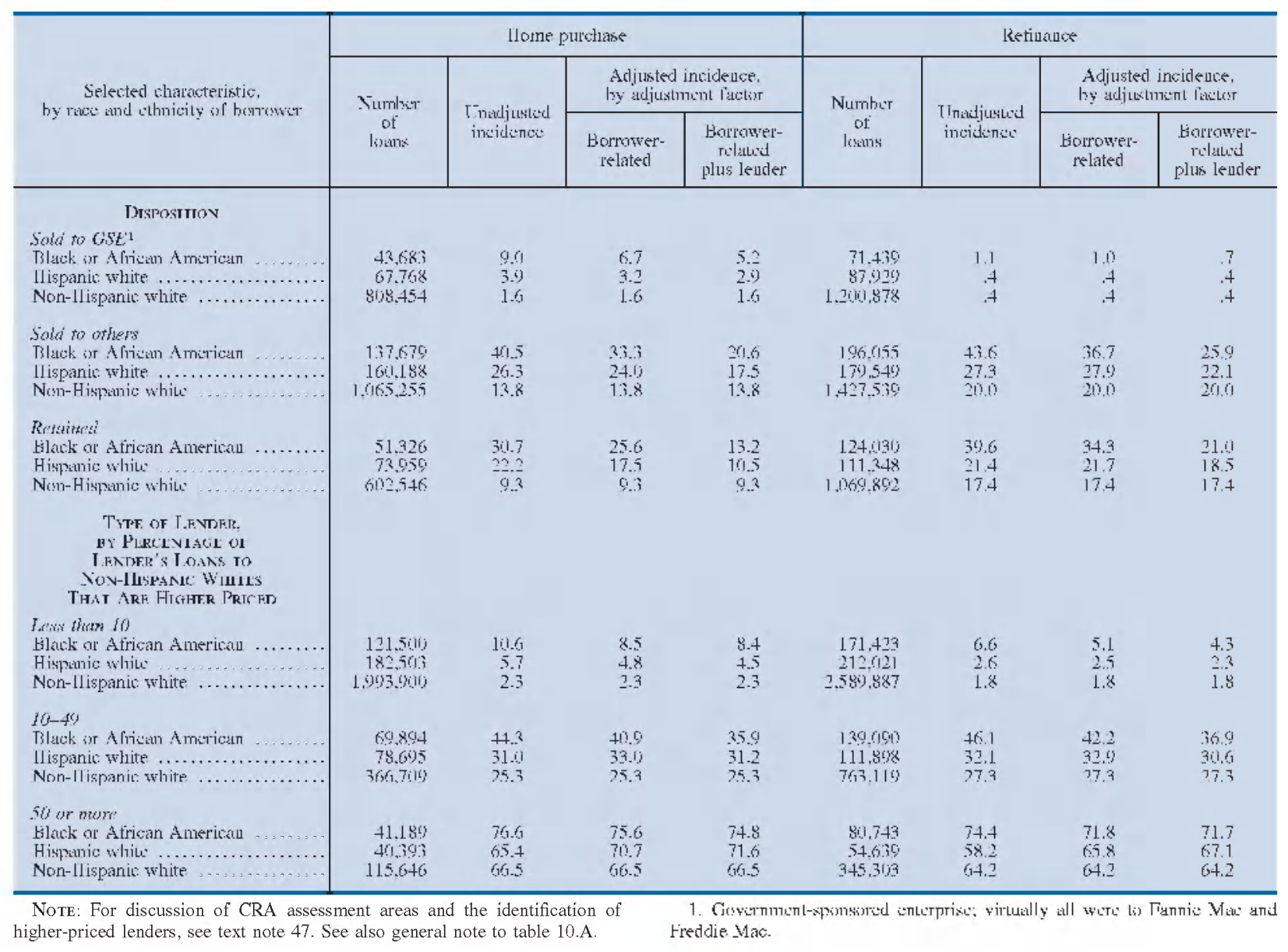

may seek loans with higher loan-to-value ratios (perhaps because on average they may have less savings to meet down-payment and closing cost requirements), which are typically higher priced and which are the specialty of certain lenders. This explanation could account for differences in lender choice, but demonstrating it requires loan-specific informationsuch as loan-to-value ratios - as well as other information that is not in the HMDA data.

However, a situation that might suggest an inadequately functioning marketplace - and that could trigger fair lending concerns-would occur if minority borrowers are incurring prices on their loans that are higher than is warranted by their credit characteristics. Such a problem could arise in one or both of the following circumstances: (1) neighborhoods with high proportions of minority residents may be less well served by lenders offering prime products, a circumstance that would make obtaining lower-priced loans more difficult for well-qualified minorities, or
(2) some minority borrowers may be steered to lenders who typically charge higher prices than the credit characteristics of these borrowers warrant. The data reported under HMDA are insufficient to tell us whether either explanation (or any other) is correct, nor do they tell us why minorities disproportionately use government-backed products.

\section{Incidence of Higher-Priced Lending for Selected Subgroups}

Although, for reasons discussed above, we cannot definitively explain the racial and ethnic pricing differences that remain after adjusting for borrowerrelated factors plus lender or the reasons that minorities may disproportionately obtain credit from higherpriced lenders, some additional insights may be gained by analyzing subgroups of lenders and borrowers (table 11). We present data only for blacks 
and Hispanic whites because they are the two minority groups whose outcomes differ most from those of non-Hispanic whites in the incidence of higher-priced lending. We also restrict the comparison to the two loan-products that account for the largest number of loans-conventional home-purchase loans and refinancings. We analyze these two minority groups and the two loan products with regard to five factors: (1) the borrower's relative income; (2) the relative income of the census tract in which the property related to the loan is located; (3) the location of the property relative to the lender's assessment area as defined under the Community Reinvestment Act of 1977 (CRA); (4) the disposition of the loan-that is, whether the loan was retained or sold and, if it was sold, to whom; and (5) the proportion of the lender's loans that are higher priced (less than 10 percent, 10-49 percent, or 50 percent or more-the last proportion being taken to indicate that the lender specializes in higher-priced lending)..$^{47}$

Results for borrowers grouped by their relative income and their census tract income classification offer little evidence that unexplained racial differences in pricing or lender choice vary by income. Although the incidence of higher-priced loans is higher for lower-income borrowers and those who live in lower-income census tracts, the same is true for all three racial groups. Thus, although unexplained price differences are somewhat lower for higher-income borrowers, price patterns are generally similar to those of the overall decompositions.

The decompositions for CRA assessment area and loan sales provide evidence on whether the channel through which a loan was obtained and the subsequent disposition of the loan affect racial or ethnic groups differently. Although the overall incidence of higher-priced loans reported in the 2004 HMDA data is much lower for loans sold to the GSEs, the data offer scant evidence that the disposition (sold or retained) is related to unexplained racial differences.

However, whether the loan was originated by an institution in its CRA assessment area does matter.

47. Larger depository institutions covered by the CRA (generally those. with assets of $\$ 250$ million or mov) art required to idsentity the census tracts in their CRA assessment areas as of the end of each calondar yoar. That information was used to determine which loans in the IIMDA data whe for poprtios within the lenders CRA assessment areas. When lenders were part of a bank holding company, the combined assessment areas of all banks in the holding company were uscd for the analysis. I ior a definition of "assessment arta," sto not: 4 to box "Rétsoms for I.oan Price Variation."

The identilication of specialists in high-priced lending was based solkly on the incidence of higher-priced lowe for non-ILispanie whites. lhis restristion prewented the idsentification from being affected by diflerences belween the pricing outcomes of blacks and Hispanics, on the one hand, and those of nom-Hispanic whiles, on the other.
Differences across groups for lending within an assessment area are about one-third of those for lending outside the assessment area. Moreover, for all racial and ethnic groups, lending within an assessment area exhibits a much lower incidence of higherpriced lending.

One possible explanation for the assessment-area effect may be that the channel through which loans are originated matters. Loans extended to borrowers outside an institution's assessment area may be more likely to have come through mortgage brokers, who may price differently or who operate in areas with different market conditions than do institutions that originate loans directly. Although this pattern may suggest that brokers charge higher prices, particularly to minorities, it is not necessarily evidence of unfair treatment or that the existence of the broker channel adversely affects minorities. It may indicate that brokers serve markets or individuals who are more costly to serve, or whose credit profiles are weaker, and price accordingly. If so, then were it not for broker activity, some of these borrowers might not be served at all or might pay higher prices. Determining whether brokers treat minority borrowers fairly is a complex undertaking and requires information unavailable in the HMDA data. The same can be said about lenders that originate loans through different channels.

Finally, although the aggregate lending patterns of specialists in higher-priced lending exhibit unexplained racial or ethnic differences, so do the aggregate patterns of other lenders to approximately the same degree. And for the higher-priced specialists with the highest incidence of higher-priced lending, differences across racial and ethnic groups are, in some instances, lower than for other lenders. Regarding the racial and ethnic differences in the lending patterns that do exist among higher-priced lending specialists, the analysis shows that income, loan amount, and other HMDA factors appear to explain little of those differences.

\section{Differences in Mean Price Spreads across Racial and Ethnic Groups}

Patterns across racial and ethnic groups for the mean spreads paid by those with higher-priced loans are quite different from patterns across such groups for the incidence of higher-priced lending (table 12). For the loan products with the largest numbers of borrowers, the unadjusted mean spreads are lower for all minority groups except blacks than they are for nonHispanic whites. Typically, Asian borrowers have the 
12. Unadjusted and adjusted mean APR spreads for higher-priced loans on one- to four-family homes,

by type of loan and by race and ethnicity and sex of borrower, 2004

A. Home purchase, owner-occupied site-built home

Percent except as noted

\begin{tabular}{|c|c|c|c|c|c|c|c|c|c|c|c|c|}
\hline \multirow{4}{*}{$\begin{array}{l}\text { Ritus and sthmicity } \\
\text { and sex }\end{array}$} & \multicolumn{8}{|c|}{ Cinventisnal } & \multirow{2}{*}{\multicolumn{4}{|c|}{ Government backed, tirst lien }} \\
\hline & \multicolumn{4}{|c|}{ Tirst licn } & \multicolumn{4}{|c|}{ Juniın lisn } & & & & \\
\hline & \multirow{2}{*}{$\begin{array}{l}\text { Number } \\
\text { wl' } \\
\text { higher- } \\
\text { rivisil } \\
\text { loans }\end{array}$} & \multirow[b]{2}{*}{$\begin{array}{l}\text { T!midjuxkid } \\
\text { meanl } \\
\text { sprasd }\end{array}$} & \multicolumn{2}{|c|}{$\begin{array}{l}\text { Adjusted mx:m xpresd } \\
\text { by adjustunent fiactor }\end{array}$} & \multirow{2}{*}{$\begin{array}{l}\text { Yumber } \\
\text { of } \\
\text { bięher- } \\
\text { prioud } \\
\text { loaus }\end{array}$} & \multirow[b]{2}{*}{$\begin{array}{l}\text { mithustud } \\
\text { mean } \\
\text { xprisd }\end{array}$} & \multicolumn{2}{|c|}{$\begin{array}{l}\text { Adjusced nn:m xproud } \\
\text { by adjustment factor }\end{array}$} & \multirow{2}{*}{$\begin{array}{l}\text { Yumber } \\
\text { of } \\
\text { higher- } \\
\text { piisid } \\
\text { locus }\end{array}$} & \multirow[b]{2}{*}{ 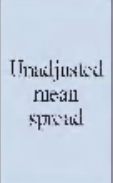 } & \multicolumn{2}{|c|}{$\begin{array}{l}\text { Adjusted mutan sproud, } \\
\text { by adjustunent factor }\end{array}$} \\
\hline & & & $\begin{array}{l}\text { Borrower- } \\
\text { nilisted }\end{array}$ & $\begin{array}{l}\text { Pastruber- } \\
\text { related } \\
\text { plus } \\
\text { lenckr }\end{array}$ & & & $\begin{array}{l}\text { Borrower- } \\
\text { ristaked }\end{array}$ & 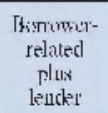 & & & $\begin{array}{l}\text { Borrower- } \\
\text { nilised }\end{array}$ & $\begin{array}{l}\text { Buntsarer- } \\
\text { related } \\
\text { plus } \\
\text { lender }\end{array}$ \\
\hline \multicolumn{13}{|l|}{ Rares artid shaticity } \\
\hline $\begin{array}{l}\text { Ameritau Indiau or } \\
\text { Alaska . Salive }\end{array}$ & $5.11 ! 1$ & 40 & 4.1 & 4.1 & 3828 & 63 & 64 & 64 & 235 & 42 & 40 & 41 \\
\hline$A \operatorname{sian} . . . \ldots \ldots \ldots$ & 11.771 & 3.8 & 4.0 & 4.0 & 11.164 & 6.2 & 6.4 & 6.4 & 137 & 4.3 & 4.2 & 4.2 \\
\hline $\begin{array}{l}\text { Black is Africim } \\
\text { American }\end{array}$ & 75477 & 17 & 17 & 1 & $30<57$ & $\mathrm{cos}$ & $=$ & 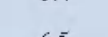 & (1) & 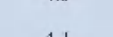 & 16 & 1. \\
\hline 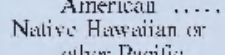 & 3,423 & 4.2 & 4.2 & 4.2 & $38,65 ?$ & 6.6 & 6.3 & $6 . \%$ & M11. & 4.1 & (4.) & 4.2 \\
\hline 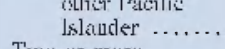 & 3,186 & 4.1) & 4.1 & 4.1 & 3.670 & 6.3 & 6.5 & 6.5 & 55 & 4.3 & 4.3 & 4.5 \\
\hline $\begin{array}{l}\text { Twwo si mirs } \\
\text { miunity races }\end{array}$ & $5 \%$ & 4.1 & 4.3 & 4.1 & $3 i 12$ & 6.4 & 6.5 & 6.5 & 82 & 3.9 & 3.6 & 4.1 \\
\hline Toint & 3.242 & 4.1 & 4.1 & 4.1 & 2662 & 6.7 & 6.5 & 6.5 & 114 & 4.2 & 4.1 & 4.2 \\
\hline Rate missing .. & 53.074 & 4.1 & 4.1 & 4.1 & 3i). $131 \mathrm{j}$ & 6.4 & 6.5 & 6.5 & 515 & 4.2 & 4.2 & 4.1 \\
\hline Hispanic while: & 61.248 & 30 & 40 & 4.1 & 501817 & 63 & 64 & 64 & 973 & 4.7 & 4.2 & 4.2 \\
\hline Non-llispanic white & $216.4 j i 9$ & 4.1 & 4.1 & 4.1 & 119.879 & 6.4 & 6.4 & 6.4 & 3,214 & 4.1 & 4.1 & 4.1 \\
\hline Sis $x$ & & & & & & & & & & & & \\
\hline Oue male.. & 173.166 & 4.6 & 4.0 & 4.6 & 10i). .257 & 6.4 & 6.4 & 6.4 & 1.,924 & 4.2 & 4.2 & 4.2 \\
\hline One fimale: & 130.250 & 4.1 & 4,10 & 40 & 77,785 & 6.7 & 6.7 & 6.4 & 1.555 & 4.2 & 4 & 4.2 \\
\hline I'wo males ...... & 3,632 & 4.1 & 4.1 & 4.1 & 2.711 & 6.3 & 6.3 & 6.3 & 126 & 4.1 & 4.1 & 4.1 \\
\hline Two fempalss ... & 3,246 & 4.1 & 40 & 4.1 & 2,261 & 64 & 63 & 63 & 83 & 40 & 3.18 & $\begin{array}{l}+.1 \\
3.9\end{array}$ \\
\hline
\end{tabular}

NotE: For definition of APR spread, see table 7, note 1. See also note to table 10.A.

12.-Continued

B. Refinance, owner-occupied site-built home

Percent except as noted

\begin{tabular}{|c|c|c|c|c|c|c|c|c|c|c|c|c|}
\hline \multirow{4}{*}{$\begin{array}{l}\text { Rivis ind sthnicity } \\
\text { and } s \mathrm{x}\end{array}$} & \multicolumn{8}{|c|}{ Connentisnal } & \multirow{2}{*}{\multicolumn{4}{|c|}{ Government backed. first lien }} \\
\hline & \multicolumn{4}{|c|}{ First lien } & \multicolumn{4}{|c|}{ Juniar lien } & & & & \\
\hline & \multirow{2}{*}{$\begin{array}{l}\text { Nunbler } \\
\text { ol } \\
\text { higher- } \\
\text { rrisid } \\
\text { louns }\end{array}$} & \multirow{2}{*}{ 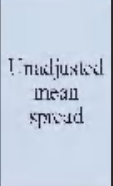 } & \multicolumn{2}{|c|}{ 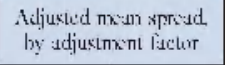 } & \multirow{2}{*}{$\begin{array}{l}\text { Yumber } \\
\text { ull } \\
\text { hizher- } \\
\text { prisid } \\
\text { loaus }\end{array}$} & \multirow{2}{*}{$\begin{array}{l}\text { muljustid } \\
\text { mean } \\
\text { xprisd }\end{array}$} & \multicolumn{2}{|c|}{$\begin{array}{l}\text { Adjusud nx:m xproud } \\
\text { by sdjusumsnl Fickur }\end{array}$} & \multirow{2}{*}{$\begin{array}{l}\text { Yunkler } \\
\text { of } \\
\text { higher- } \\
\text { misid } \\
\text { loulls }\end{array}$} & \multirow{2}{*}{$\begin{array}{l}\text { Thnuljustivd } \\
\text { neatul } \\
\text { sprial }\end{array}$} & \multicolumn{2}{|c|}{ 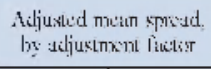 } \\
\hline & & & $\begin{array}{l}\text { Pismumer- } \\
\text { related }\end{array}$ & $\begin{array}{l}\text { Borrower- } \\
\text { nilued } \\
\text { plus } \\
\text { kindr }\end{array}$ & & & $\begin{array}{l}\text { Thanimer- } \\
\text { related }\end{array}$ & $\begin{array}{l}\text { Borrower- } \\
\text { rivluted } \\
\text { plus } \\
\text { kindr }\end{array}$ & & & \begin{tabular}{|l} 
Bastisaser- \\
celated
\end{tabular} & $\begin{array}{l}\text { Borrower- }- \\
\text { niluted } \\
\text { plus } \\
\text { leinder }\end{array}$ \\
\hline \multicolumn{13}{|l|}{$\begin{array}{l}\text { Ratre and efhaticity } \\
\text { American Tndian or }\end{array}$} \\
\hline Alaska _ative & 8,977 & 4.1 & 4.2 & 4.1 & $80 j$ & 7.2 & 6.8 & 7.1 & 98 & 4.1 & $4.6 j$ & 3.8 \\
\hline $\begin{array}{l}\text { A siam .............. } \\
\text { Hilack or African }\end{array}$ & 12,250 & 35 & 4.1 & 4.1 & 2,675 & 6.5 & 69 & 7.1 & 91 & 4.4 & 3.7 & 3.8 \\
\hline American .... & 135,467 & 43 & 4.3 & 43 & 10,974 & 7.5 & 7.2 & 7.2 & 456 & 37 & 3.8 & 3.8 \\
\hline $\begin{array}{l}\text { Native Ilawaiiau or } \\
\text { chlice Pacilii } \\
\text { lslauder ...... }\end{array}$ & $5,1.53$ & 4.1. & 4.2 & 4.2 & 81.1 & 6.8 & 7.1 & 7.1 & 34 & 5.1 & 3.7 & 3,6 \\
\hline Two or mist & 1072 & 40 & 4 & 41 & 76 & 6.8 & 70 & 73 & 6.5 & 30 & 30 & 30 \\
\hline Ioint ............. & 6,973 & 4.1 & 4.2 & 4.2 & 1,308 & 7.0 & 7.1 & 7.1 & 50 & 3.6 & 3.8 & 3.6 \\
\hline Race missing .. & 150,741 & 42 & 4.2 & 42 & 26915 & 7.6 & 73 & 7.2 & 603 & 38 & 30 & 30 \\
\hline Ilispanit white ..... & 73,181 & 4.5 & 4.1 & 4.2 & 7.255 & 6.9 & 70 & 7.1 & 408 & 4.4 & 4.0 & 3.9 \\
\hline Non-Hikpanic while & 476194 & 4.2 & 4.2 & 4.2 & 68,211 & 7.1 & 7.1 & 7.1 & 2,002 & 3.8 & 38 & 3.8 \\
\hline $\operatorname{Sic} x$ & & & & & & & & & & & & \\
\hline Oue male .. & 252,618 & 4.1 & 4.1 & 4.1 & 30,905 & 7.1 & 7.1 & 7.1 & 895 & 3.5 & 3.9 & 3.i) \\
\hline Onis fiemale & $232,5 \times 3$ & 4.2 & 4.2 & 4.1 & 21.019 & 7.1 & 7.1 & 7.1 & 823 & 39 & 39 & 3.8 \\
\hline l'wo males ....... & 4.833 & 4.3 & 4.2 & 4.2 & 314 & 7.0 & 7.10 & 7.6 & 68 & 4.1 & 4.1 & 4.1 \\
\hline Twoe femalises ..... & 7,479 & 43 & 4.2 & 4.2 & 914 & 7.2 & 69 & 7.0 & 55 & 39 & 4.1 & 4.3 \\
\hline
\end{tabular}

Note: See note to table 12.A. 
12. Unadjusted and adjusted mean APR spreads for higher-priced loans on one- to four-family homes, by type of loan and by race and ethnicity and sex of borrower, 2004 - Continued

C. Home improvement, conventional loan, owner-occupied site-built home Percent except as noted

\begin{tabular}{|c|c|c|c|c|c|c|c|c|}
\hline \multirow{3}{*}{$\begin{array}{l}\text { Ratec and whnicity } \\
\text { and } \operatorname{ses}\end{array}$} & \multicolumn{4}{|c|}{ First lism } & \multicolumn{4}{|c|}{ Junies lien } \\
\hline & \multirow{2}{*}{$\begin{array}{l}\text { Number } \\
\text { of } \\
\text { highter- } \\
\text { prisced } \\
\text { listans }\end{array}$} & \multirow{2}{*}{$\begin{array}{l}\text { Tonadjustied } \\
\text { mian } \\
\text { spread }\end{array}$} & \multicolumn{2}{|c|}{$\begin{array}{l}\text { Adjusted mean spread, } \\
\text { by adjustment factor }\end{array}$} & \multirow{2}{*}{$\begin{array}{c}\text { Number } \\
\text { of } \\
\text { highter- } \\
\text { priced } \\
\text { lesanss }\end{array}$} & \multirow{2}{*}{$\begin{array}{l}\text { TIniwjusuled } \\
\text { meen } \\
\text { spread }\end{array}$} & \multicolumn{2}{|c|}{$\begin{array}{l}\text { Adjusted meau spread. } \\
\text { by adjustmeut factor }\end{array}$} \\
\hline & & & $\begin{array}{l}\text { Thansower- } \\
\text { related }\end{array}$ & $\begin{array}{l}\text { Thorrinwer- } \\
\text { related } \\
\text { plusi linder }\end{array}$ & & & $\begin{array}{c}\text { Benrewrec- } \\
\text { related }\end{array}$ & 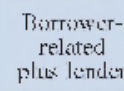 \\
\hline \multicolumn{9}{|l|}{ Reree and eshaticity } \\
\hline Americau Indiau or Alaska Cative & 883 & 4.5 & 4.6 & 4.4 & 493 & 7.7 & 76 & 7.8 \\
\hline Asiann ........................... & 752 & 30 & 4.3 & 4.4 & 875 & 7.5 & 7.8 & 79 \\
\hline Black or A ficican American & 11.770 & 4.6 & 46 & 4.5 & 7,389 & 8.4 & 8.3 & 8.1 \\
\hline \multirow{6}{*}{ 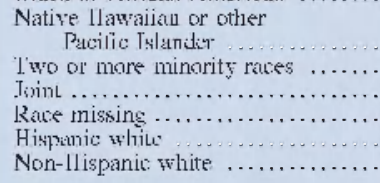 } & 397 & 42 & 4.4 & 4.5 & 463 & 79 & 801 & 7.7 \\
\hline & 76 & 4.4 & 4.3 & 4.3 & 32 & 7.7 & 7.9 & 66 \\
\hline & 6015 & 4.4 & 4.5 & 4.4 & 800 & 7.8 & 8.1 & 8.2 \\
\hline & 7.92010 & 4.5 & 4.6 & 4.5 & 10,633 & 7.9 & 8.2 & 801 \\
\hline & 7.572 & 4.3 & 4.3 & 4.4 & 3,255 & 7.7 & 8.1 & 801 \\
\hline & 43.2019 & 4.4 & 4.4 & 4.4 & 41,410 & 7.9 & 7.9 & 7.9 \\
\hline \multicolumn{9}{|l|}{ Sex } \\
\hline Oue male... & 19344 & 4.4 & 4.4 & 4.4 & 17,425 & 8.2 & 8.2 & 8.2 \\
\hline One fimale .............. & 20,1104 & 4.4 & 4.4 & 4.4 & 12,873 & 8.1 & 8.1 & 8.1 \\
\hline l'wo males ................. & 438 & 4.3 & 4.3 & 4.3 & 457 & 7.9 & 7.9 & $7.9)$ \\
\hline Twes femralies ................ & 729 & 46 & 4.4 & 4.1 & 532 & 80 & 80 & 79 \\
\hline
\end{tabular}

Note: See note to table 12.A.

\section{2.-Continued}

D. Manufactured housing, conventional loan, first lien, owner-occupied home Percent except as noted

\begin{tabular}{|c|c|c|c|c|c|c|c|c|}
\hline \multirow{3}{*}{$\begin{array}{l}\text { Rixe and ethmicity } \\
\text { and ses }\end{array}$} & \multicolumn{4}{|c|}{ Home purchise } & \multicolumn{4}{|c|}{ Relinani: } \\
\hline & \multirow{2}{*}{$\begin{array}{l}\text {-iumber } \\
\text { of } \\
\text { higher- } \\
\text { pricidd } \\
\text { lisams }\end{array}$} & \multirow{2}{*}{$\begin{array}{l}\text { Tondjustid } \\
\text { mean } \\
\text { sproad }\end{array}$} & \multicolumn{2}{|c|}{$\begin{array}{l}\text { Adjusted mean spread. } \\
\text { by adjuxtment lactist }\end{array}$} & \multirow{2}{*}{$\begin{array}{l}\text { Number } \\
\text { ol } \\
\text { higher- } \\
\text { pricud } \\
\text { lesuns }\end{array}$} & \multirow{2}{*}{$\begin{array}{l}\text { TImidjustud } \\
\text { meaul } \\
\text { spriad }\end{array}$} & \multicolumn{2}{|c|}{$\begin{array}{l}\text { Adjusted mean spread. } \\
\text { by adjuximient fikitust }\end{array}$} \\
\hline & & & $\begin{array}{c}\text { Thonowar- } \\
\text { related }\end{array}$ & $\begin{array}{l}\text { Borrower- } \\
\text { rolaud } \\
\text { plus leuder }\end{array}$ & & & $\begin{array}{l}\text { Bomrousci- } \\
\text { related }\end{array}$ & $\begin{array}{l}\text { biorrower- } \\
\text { rolawid } \\
\text { plus leuder }\end{array}$ \\
\hline \multicolumn{9}{|l|}{ Reres artal eshaticity } \\
\hline Americau Indiau or Alaska Native .. & $7 i) 6$ & 6.0 & 6.0 & 5.9 & 266 & 5.4 & 5.3 & 4.9 \\
\hline Asiam .............................. & 337 & 5.4 & 5.5 & 5.5 & 90 & 4.9 & 5.7 & 5.7 \\
\hline Hlack or African Americal .......... & 4,060 & $6.1)$ & 5.9 & 5.6 & 1.567 & 5.4 & 5.3 & 5.3 \\
\hline Pacilic Tslander .......... & 223 & 58 & 6.1 & 66 & 40 & 4.8 & 50 & 5.1 \\
\hline l'wo or more minority races ............... & lị & 5.6 & 6.8 & 5.3 & 11 & 3.9 & 4 & 3.2 \\
\hline $\mathrm{I}_{\text {ivint }} \ldots \ldots \ldots \ldots \ldots \ldots \ldots \ldots \ldots$ & 535 & 5.6 & 58 & 5.7 & 234 & 4.9 & 5.1 & 5.1 \\
\hline Race missing ............... & 3.738 & 5.9 & 5.3 & 5.7 & $4 . \overline{370}$ & 4.8 & 4.7 & 4.9 \\
\hline Hispamic whlo . ............ & 3.777 & 60 & 6.1 & 60 & 1.0 .51 & 50 & 50 & 5.1 \\
\hline Non-llispanit white ........... & 41.725 & 5.6 & 5.6 & 5.6 & 26,104 & $5 . i$ & $5 . i$ & $5-1$ \\
\hline \multicolumn{9}{|l|}{ Stex } \\
\hline One malis ............... & 17.145 & 58 & 58 & 5.8 & 8.350 & 50 & 50 & 501 \\
\hline Oue female $\ldots \ldots \ldots \ldots$ & 13.413 & 5.7 & 5.7 & 5.7 & 6,363 & 5.1 & $5 i 1$ & $5 i$ \\
\hline l'wo males $\ldots \ldots \ldots \ldots . .$. & $1 . j 1^{i}$ & 5.6 & 5.9 & 5.6 & 315 & 5.4 & 5.4 & 5.4 \\
\hline 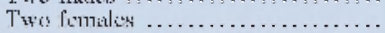 & 1,0015 & 5.7 & 56 & 60 & 204 & 5.4 & 5.3 & 5.7 \\
\hline
\end{tabular}

Note: See note to table 12.A.

lowest mean spreads. Furthermore, adjusting for differences in loan amounts, incomes, and other HMDA factors plus lender either does little to the average spreads or changes them in different directions for different groups. One consistent difference that persists after adjustment is the difference between blacks and non-Hispanic whites. After adjustment, the gap in the mean spreads between these groups for the most common loan products is between 0.10 and 0.15 percentage points.

\section{Differences in Pricing by Sex of Borrower}

As with denial rates, there is little evidence of systematic differences in pricing when borrowers are 
12. Unadjusted and adjusted mean APR spreads for higher-priced loans on one- to four-family homes, by type of loan and by race and ethnicity and sex of borrower, 2004-Continued

E. Nonowner-occupied site-built home

Percent except as noted

\begin{tabular}{|c|c|c|c|c|c|c|c|c|c|c|c|c|}
\hline \multirow{4}{*}{$\begin{array}{l}\text { Rivis and slmicity } \\
\text { and sex }\end{array}$} & \multicolumn{8}{|c|}{ Conmentimal, lixst lisn } & \multirow{2}{*}{\multicolumn{4}{|c|}{ Other ${ }^{1}$}} \\
\hline & \multicolumn{4}{|c|}{ Hisme purchiss } & \multicolumn{4}{|c|}{ Refinence } & & & & \\
\hline & \multirow{2}{*}{$\begin{array}{l}\text { Numb:r } \\
\text { ol } \\
\text { highher- } \\
\text { pricsid } \\
\text { loans }\end{array}$} & \multirow[b]{2}{*}{$\begin{array}{l}\text { T'mialjuxkil } \\
\text { meall } \\
\text { sprusd }\end{array}$} & \multicolumn{2}{|c|}{$\begin{array}{l}\text { Ridjusled mx:m xprsidd } \\
\text { by adjustunent factor }\end{array}$} & \multirow{2}{*}{$\begin{array}{c}\text { Yumbxr } \\
\text { of } \\
\text { lighlaer- } \\
\text { privid } \\
\text { loans }\end{array}$} & \multirow[b]{2}{*}{$\begin{array}{l}\text { mitiljuxted } \\
\text { mean } \\
\text { xpridd }\end{array}$} & \multicolumn{2}{|c|}{$\begin{array}{l}\text { Adjusted mim xproud. } \\
\text { by adjustnent factor }\end{array}$} & \multirow{2}{*}{$\begin{array}{c}\text { Vumber } \\
\text { of } \\
\text { higher- } \\
\text { privid } \\
\text { louns }\end{array}$} & \multirow[b]{2}{*}{$\begin{array}{l}\text { TThudjuskid } \\
\text { neall } \\
\text { spritid }\end{array}$} & \multicolumn{2}{|c|}{$\begin{array}{l}\text { Adjuxisted meun sprsid, } \\
\text { by adjustunent factor }\end{array}$} \\
\hline & & & $\begin{array}{l}\text { Borrower- } \\
\text { nilited }\end{array}$ & $\begin{array}{l}\text { Bistumer- } \\
\text { related } \\
\text { plus } \\
\text { lencker }\end{array}$ & & & $\begin{array}{l}\text { Borrower- } \\
\text { wislud }\end{array}$ & $\begin{array}{l}\text { Thisnower- } \\
\text { related } \\
\text { plux } \\
\text { lender }\end{array}$ & & & $\begin{array}{c}\text { Borrower- } \\
\text { nilitid }\end{array}$ & $\begin{array}{l}\text { Bungiswer- } \\
\text { related } \\
\text { plus } \\
\text { lendler }\end{array}$ \\
\hline \multicolumn{13}{|l|}{ Rare atrol eshotic ity } \\
\hline $\begin{array}{l}\text { Americau Indian or } \\
\text { Alusk Salivi ... }\end{array}$ & 603 & 30 & 4.1 & 4.1 & 623 & 4.1 & 4.3 & 43 & 288 & 6.5 & 6.2 & 6.3 \\
\hline Asian...$\ldots \ldots \ldots$ & 2.476 & 3.9 & 3.9 & 4.0 & 1.319 & 3.9 & 4.0 & 4.1 & 1.419 & 6.5 & 6.2 & 6.1 \\
\hline Bluck is A fivicum & & & & & & & & & & & & \\
\hline $\begin{array}{l}\text { American } \ldots . . . \\
\text { Nialifo Hatwatian or }\end{array}$ & 17.841 & 4.2 & 4.1 & 4.1 & 15.731 & 4.3 & 4.3 & 4.3 & 5.197 & 6.5 & 6.3 & 6.2 \\
\hline $\begin{array}{l}\text { shlyer Pacilie } \\
\text { Islauder ........ }\end{array}$ & $53 !$ & 4.j) & 4.0 & 3.9 & 388 & 4.2 & 4.4 & 4.8 & 298 & 6.7 & 6.3 & 6.2 \\
\hline $\begin{array}{l}\text { T'wo ar mor: } \\
\text { minority races ... }\end{array}$ & 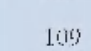 & 4.1 & 4.4 & 4.1 & 105 & 3.9 & 3.9 & 3.7 & 37 & 6.7 & 6.2 & 6.7 \\
\hline Tivint & 637 & 4.10 & 4.7 & 3.9 & 444 & 4.2 & 4.2 & 40 & 390 & 6.5 & 6.4 & 60 \\
\hline Race missing $\ldots \ldots \ldots$. & 8.816 & 4.1 & 4.1 & 4.1 & 9995 & 4.2 & 4.3 & 4.2 & 5.698 & 6.7 & 6.3 & 6.3 \\
\hline Hispomic while & 6831 & 3.0 & 4.0 & 4.0 & 50102 & 4.1 & 4.2 & 4.2 & 3,718 & 63 & 6.2 & 6.1 \\
\hline Non-llispanit white . & 47.211 & 4.0 & 4.0 & 4.0 & 35930 & 4.1 & 4.1 & 4.1 & 34,622 & 6.1 & 6.1 & 6.1 \\
\hline \multicolumn{13}{|l|}{$\sin x$} \\
\hline Oue male ............ & 38.917 & 4.0 & 4.0 & 4.0 & 28,824 & 4.2 & 4.2 & 4.2 & 16.711 & 6.4 & 6.4 & 6.4 \\
\hline One fimale & 19.340 & 40 & 40 & 40 & 16004 & 4.2 & 4.2 & 4.2 & 8.774 & 63 & 63 & 6.4 \\
\hline l'wo males ........... & 1,6015 & 4.1 & 4.1 & 4.1 & 718 & 4.1 & 4.1 & 4.1 & 688 & 6.3 & 6.3 & 6.3 \\
\hline 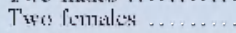 & 480 & 4.1 & 4.2 & 5.4 & 396 & 4.4 & 4.1 & 40 & 350 & 6.5 & 6.2 & 6.4 \\
\hline
\end{tabular}

Note: See note to table $12 . \mathrm{A}$

1. See table 1 lij.E., note 1 .

distinguished by sex (table 10). The differences in the unadjusted incidence of higher-priced lending are almost always small across loan products and generally narrow when HMDA factors plus lender are taken into account. Of the nineteen loan product comparisons with evidence of some pricing difference by sex, males have a higher incidence of higherpriced loans in nine cases, while females do in ten cases. Nearly identical patterns are exhibited for mean spreads, and there is no evidence that one sex consistently pays more than the other (table 12).

\section{The Role of Factors Not Included in HMDA}

An important limitation of the decompositions reported earlier is that controls were possible only for borrower-related factors included in the HMDA data plus lender when assessing differences in loan pricing among racial, ethnic, or other groups. As noted, many factors relevant to underwriting and pricing are not included in the HMDA data and thus cannot be accounted for in analyses that rely exclusively on the data. To provide some insight into how important controlling for these other factors might be in accounting for pricing differences across borrower groups, we collaborated with Georgetown Univer- sity's Credit Research Center (CRC) to perform additional analyses using a CRC database. The CRC data consist of both HMDA data and a wide range of other loan-level factors not in the HMDA data that may relate to credit underwriting and pricing.

The CRC data, which were provided by eight lenders that specialize in subprime lending, are equivalent to the 2004 HMDA filings of those lenders (for the loans they originated) plus non-HMDA information on many other characteristics of the loans and borrowers. ${ }^{48}$ The non-HMDA information consists of credit history scores (in this instance, FICO scores), loan-to-value ratios for first-lien loans, the appraised value of property, and information on whether the interest rate on the loan was adjustable or fixed, whether underwriting for the loan waived certain certifications by the borrower (that is, whether the loan was a "low documentation" product), whether the loan carried a prepayment penalty, and whether the loan was originated through a broker. Unlike the HMDA data, the CRC data are not disaggregated

48. The eight subprime mortgatye lenders are subsicliaries of large financial instilutions. The 2004 data from these lenclers comsist of about 626,000 loans that they originated; mor than 60 present of the loans in that group are higher-pricod. The data trom thess: subprims: lemelers haţe been used in various research iniliatiłes and public policy deliberations. 
13. Loan pricing by eight subprim، specialists, conventional first-lien loans on owner-occupied one- to four-family homes, by type of loan and by selected race and ethnicity of borrower, 2004

A. Unadjusted and adjusted incidence of higher-priced lending

Percent except as noted

\begin{tabular}{|c|c|c|c|c|c|c|c|c|}
\hline \multirow[b]{3}{*}{ Rike and ethnicity } & \multicolumn{4}{|c|}{ Home purcliaxio } & \multicolumn{4}{|c|}{ Refinane: } \\
\hline & \multirow[b]{2}{*}{$\begin{array}{l}\text { Number } \\
\text { is' losans: }\end{array}$} & \multirow[b]{2}{*}{$\begin{array}{l}\text { Lnadjusted } \\
\text { incidience }\end{array}$} & \multicolumn{2}{|c|}{$\begin{array}{l}\text { Adjusted incideuce, } \\
\text { by adjustment factor }\end{array}$} & \multirow[b]{2}{*}{$\begin{array}{l}\text { Number } \\
\text { oil lisans }\end{array}$} & \multirow[b]{2}{*}{$\begin{array}{l}\text { IInadiusted } \\
\text { incidience }\end{array}$} & \multicolumn{2}{|c|}{$\begin{array}{l}\text { Adjusted incideuce, } \\
\text { by adjustmeut tactor }\end{array}$} \\
\hline & & & $\begin{array}{l}\text { Thenาiswer- } \\
\text { related }\end{array}$ & $\begin{array}{l}\text { Thorrinwer- } \\
\text { related } \\
\text { plus } \\
\text { non-llyDA } \\
\text { writi } \\
\text { tactors }\end{array}$ & & & $\begin{array}{l}\text { Pumbuper- } \\
\text { related }\end{array}$ & $\begin{array}{l}\text { Bomronwer- } \\
\text { related } \\
\text { plus } \\
\text { nou-LMLA } \\
\text { wedit } \\
\text { factors }\end{array}$ \\
\hline Black ar A fician American & 6,360 & 85.8 & 84.4 & 839 & 37.354 & 829 & 819 & 80.7 \\
\hline $\begin{array}{l}\text { Ilispanit: white } \ldots \ldots \ldots \ldots \ldots \\
\text { Nen-Hispanic while }\end{array}$ & $\begin{array}{r}6.1101 \\
30,224\end{array}$ & $\begin{array}{l}72.6 \\
82.9\end{array}$ & $\begin{array}{l}83.3 \\
82.9\end{array}$ & $\begin{array}{l}83.1 \\
82.9\end{array}$ & $\begin{aligned} 12.80 i 01 \\
1.3566 ?\end{aligned}$ & $\begin{array}{l}7.7 \\
80.7\end{array}$ & $\begin{array}{l}78.8 \\
80.7\end{array}$ & $\begin{array}{l}801,9 \\
8017\end{array}$ \\
\hline
\end{tabular}

NoTE: Includes transition-period loans (those for which the application was submitted before 2004). For details on higher-priced lending, the :ubprimu lenders, and the adjustment factors, see text and text note 49 . For method of alloca.

tion into racial and ethnit cateso

Soukc: Credit Research Center, Georgetown Liniwersity

13.-Continued

B. Unadjusted and adjusted mean APR spreads for higher-priced loans

Percentage points except as noted

\begin{tabular}{|c|c|c|c|c|c|c|c|c|}
\hline \multirow[b]{3}{*}{ Race and ethuicity } & \multicolumn{4}{|c|}{ Heme purshase } & \multicolumn{4}{|c|}{ Relinanes } \\
\hline & \multirow[b]{2}{*}{$\begin{array}{l}\text { Tumblye } \\
\text { of } \\
\text { highter- } \\
\text { priseed } \\
\text { liswans }\end{array}$} & \multirow[b]{2}{*}{$\begin{array}{l}\text { Lnadjusted } \\
\text { spread }\end{array}$} & \multicolumn{2}{|c|}{$\begin{array}{l}\text { Adjuxled spread, } \\
\text { by adjustment factor }\end{array}$} & \multirow[b]{2}{*}{$\begin{array}{l}\text { Number } \\
\text { of } \\
\text { highther- } \\
\text { priced } \\
\text { lesums: }\end{array}$} & \multirow[b]{2}{*}{$\begin{array}{l}\text { I- Iuadjusted } \\
\text { sprieud }\end{array}$} & \multicolumn{2}{|c|}{$\begin{array}{l}\text { Adjustid sproded, } \\
\text { by adjustment tactor }\end{array}$} \\
\hline & & & $\begin{array}{c}\text { Then:ower- } \\
\text { related }\end{array}$ & $\begin{array}{l}\text { Thimsinet- } \\
\text { related } \\
\text { plus } \\
\text { nou-lIMDA } \\
\text { credit } \\
\text { Laciors }\end{array}$ & & & $\begin{array}{l}\text { Benreswer- } \\
\text { related }\end{array}$ & 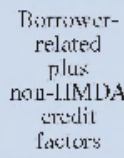 \\
\hline $\begin{array}{l}\text { black of African Americau } \\
\text { Hispanic while ............ }\end{array}$ & $\begin{array}{l}5.463 \\
4,437\end{array}$ & 5.1 & $\begin{array}{l}5.1 \\
4.9\end{array}$ & $\begin{array}{l}5.0 \\
4.9\end{array}$ & $\begin{array}{r}30,95 i) \\
0,183\end{array}$ & $\begin{array}{l}5.1 \\
4.7\end{array}$ & $\begin{array}{l}5.1 \\
4.8\end{array}$ & $\begin{array}{l}5.1 \\
40\end{array}$ \\
\hline Non-Ilispanit white ....... & 25.653 & 4.9 & 4.9 & 4.9 & $109) .524$ & 5.0 & 5.10 & 50 \\
\hline
\end{tabular}

Note: For definition of APR spread, see table 7, note 1 . See also notes to table 13.A.

by individual lender; consequently, the analysis of the data could not control for lender. Together, the eight lenders accounted for about 22 percent of the higher-priced conventional first- or junior-lien homepurchase or refinance loans related to owner-occupied properties reported by HMDA filers for 2004 .

The CRC analyzed pricing differences among the combined filings of the eight lenders in a manner identical to that used to prepare table 10 - that is, using only data reported in HMDA-and then it extended the adjustment of differences by using the non HMDA items in its database. ${ }^{4}$ The number of loans in the CRC database was sufficient to allow meaningful analysis of conventional home-purchase and refinance loans on one- to four-family, site-built, owner-occupied homes for two minority groups-

49. Only loans with complets intomation on all rovent factors Wher ust in the analysis. Loans with missing intomation for any factor hact a some what lower incidence of higher-priced lending than tich the loans used in the analysis. blacks and Hispanic whites-and for non-Hispanic whites.

For pricing outcomes for conventional first-lien home-purchase loans from the eight lenders, as adjusted for borrower-related factors (that is, using only the HMDA data), the incidence of higher-priced lending differs between black and non-Hispanic white borrowers by 1.5 percentage points and between Hispanic white and non-Hispanic white borrowers by 0.3 percentage point (table 13 ). When additional factors available only in the CRC data are taken into account, the differences between black and nonHispanic white borrowers and between Hispanic white and non-Hispanic white borrowers falls about one-third. For refinance loans, the 1.2 percentage point gap between black and non-Hispanic white borrowers that remains after controlling for HMDA data items is removed when additional factors in the CRC database are controlled for. With respect to mean APR spreads for these loan products, gross 
differences across racial or ethnic groups (that is, differences that exist in the raw, or unadjusted, data) are de minimus, a fact little changed by adding more controls from either the HMDA or the CRC data.

These results suggest that an analysis employing comprehensive information on specific loan products (for example, different types of adjustable-rate loans) from specific lenders-information unavailable in the HMDA or CRC data-would be required to draw firm conclusions about racial or ethnic differences in pricing.

USING THE EXPANDED HMDA DATA AS A SCREENING TOOL FOR FAIR LENDING ENFORCEMENT

Ensuring compliance with the nation's fair lending laws is one of the responsibilities of the federal and state agencies that regulate financial institutions. For some time, the Federal Reserve has been using a statistical analysis system that relies on the HMDA data to help assess fair lending compliance by highvolume mortgage lenders. The system identifies which supervised institutions and which loan products and geographic markets show meaningful differences in the denial rates of loan applications by the race, ethnicity, or sex of the borrower and thus warrant greater supervisory attention. The statistical analysis system measures differences in denial rates by comparing applications for a specific loan product filed by applicants who differ by race, ethnicity, or sex but who are matched on the basis of the limited set of items in the HMDA data. For example, the analysis can focus on denial rates of whites, Hispanic whites, and blacks by comparing the denials of applicants from each of those groups who sought the same loan product for about the same loan amount, are from the same metropolitan area, and have similar incomes, dates of application, and number of applicants in the transaction. The statistical analysis system also provides compliance examiners with a specific list of matched application files to review during the on-site part of an examination.

The expanded data provide opportunities to improve the statistical analysis system in two ways. First, some of the new data items can be used to refine the existing system of analyzing denial rates of loan applications by allowing more precise differentiation among loan products. Lien status and manufactured-home designation are prominent examples because both typically have significant roles in loan underwriting. Second, the new loanpricing information provides opportunities to expand the statistical analysis beyond the disposition of applications to differences in loan pricing. The data can be reviewed for differences across groups in the incidence of higher-priced lending and in average spreads paid by borrowers with loans priced above the thresholds. The pricing data can also be reviewed for broader patterns that may indicate fair lending issues. For example, an institution's overall lending activity can be reviewed to identify geographic variations in pricing that may be associated with neighborhood racial or ethnic population characteristics. Each of these approaches will improve the fair lending analyses conducted by examiners.

\section{Screening Using the 2004 HMDA Data}

As of this writing, the Federal Reserve has modified its statistical analysis system for fair lending examinations to incorporate the new information available in the expanded HMDA data. To examine the potential utility of the enhanced system, we used a streamlined version of the system to conduct a review of the lending activity of the 8,853 institutions reporting 2004 HMDA data. The approach here and in the earlier sections of this article are related, but unlike the earlier sections, which involved an analysis of aggregate patterns that included a control for lender, this exercise uses the data to identify patterns in the lending of individual institutions.

The streamlined analysis starts by evaluating the statistical significance of differences across racial or ethnic lines in the unadjusted (or gross) incidence of denial rates, incidence of higher-priced lending, and average spreads paid by those with higher-priced loans for each lender separately. This procedure produces a series of lender-product combinations. For each lender-product combination, further analysis matches each minority applicant (or borrower) with nonminority applicants (or borrowers) on the basis of a variety of factors available in the HMDA data, including loan product, borrower income and loan amount, geographic market (for example, specific MSA), and number of applicants (one or more than one).

Adjusted differences are computed by comparing the denial rates, incidence of higher-priced lending, and average APR spreads of minorities with those of the tomminorilies matched to them. This procedure is designed to remove the effects of these other factors from the calculations of the differences. The adjusted differences are an estimate of the expected differences in outcomes if a minority and a aonminority with the same income, loan amount, and number of 
applicants applied for the same loan product, at the same institution, in the same market.

The streamlined analysis used for purposes of this article relies on publicly available data as well as data filed under HMDA that are not subject to public disclosure (the dates an application was filed and acted on). A picture of the outcomes of the statistical analysis system with regard to the analysis of denial rates or pricing can be conveyed by reviewing the number of loan products for which the system indicates a statistically significant difference between blacks and Hispanics (as a group) and non-Hispanic whites in denial rates, in the incidence of higherpriced lending, or in the mean differences in pricing for those with higher-priced loans. ${ }^{50}$ The focus of the streamlined analysis is on the eight owner-occupied product areas that account for the vast majority of owner-occupied loans in the 2004 HMDA data. ${ }^{51}$

In total, there are 13,260 lender-product combinations for the 8,853 HMDA reporting institutions that have at least one black or Hispanic borrower who can be matched (for comparison) to at least one nonHispanic white borrower. Of the 13,260 lenderproduct combinations, 2,418 have at least fifty black or Hispanic borrowers and at least fifty non-Hispanic white borrowers, numbers that provide a more meaningful basis for comparison.

For the black and Hispanic group and the nonHispanic white group, we have calculated, for the 13,260 lender-product combinations, the distribution across the categories of the statistical significance of three indicators-the difference in denial rates (table 14), in the incidence of higher-priced lending (table 15), and in the mean spreads for loans above the threshold (table 16). We differentiate between situations in which the black and Hispanic group has

50. Black and Hispanic borrowers wele selected for this review because these groups goncrally showed the greatest differences from non-Ilispanic whites. The groups was combined to have sutticient numbers for a meaningful statistical companisom. The "Hispanic" category used here includes all borrowers designated as ILispanic regardless of their race. This definition differs from that used in the previous section, which restricted the calegory of "Hispanics" to white Hispanics.

51. The eight products are virtually the same as those portrayed in table 9 with the modifications of (1) adding ritinance and hom:improvement first liens to the manufacturect-housing produch areat and (2) combining the homs-improvement and junior-lisen refinancing products and sxpanding the category to include government-backed loans. Combining protucts for this exercise wats done purely for the purpose of paralleling the way products are srouped in the Federal Restrw's statistical analysis system. The key product areas are identical to those used for lables 7 and 8 . The proctuct groupings do not affect the actual matching procedure because minority bonowers are always matched with non-ILispanic white borrowers with bxastly the same product as defined using all the information available in IIML $A$. Tramsilion-period applications were used in the denial-rate comparisom but not in the comparisons for pricings. an indicator (denial rate, incidence of higher-priced loans, or mean spread) that is greater than that for the non-Hispanic white group and situations in which an indicator is lower for the black and Hispanic group than for the non-Hispanic white group. Differences are presented in two ways: (1) as the distribution of the statistical significance of the unadjusted rate or incidence and (2) for each unadjusted category, as the distribution of the statistical significance that remains after the statistical analysis system has been applied. The categories of statistical significance are, from highest to lowest level of significance, 1 percent, 5 percent, 10 percent, and not statistically significant.

\section{Denial Rates}

Of the 13,260 lender-product combinations, 3,075, or 23 percent, are those in which the minority group has an unadjusted denial rate that is different from that of the non-Hispanic white group by a statistically significant amount. In almost all of these cases, the black and Hispanic denial rate is higher, although the reverse holds in 4 percent of the cases. Eleven percent of the lender-product combinations show a statistically significant difference in denial rates after the matching procedure is employed ( 6 percent at the 1 percent significance level), and only 2 percent of the 11 percent show a lower denial rate for blacks and Hispanics.

\section{Incidence of Higher-Priced Loans}

Of the 13,260 lender-product combinations, 1,148, or 9 percent, have a statistically significant difference between the minority and nonminorily groups in the unadjusted incidence of higher-priced lending. Most of the significant differences show a higher incidence for the black and Hispanic group, although about 8 percent show a lower incidence. Employing the matching process to control for differences in income, loan amount, and other HMDA factors reduces the number of statistically significant differences by more than one-half. Of the lender-product combinations that are statistically significant at the 1 percent level when unadjusted differences are evaluated, fewer than one-half ( 2 percent of the total number of lender-product combinations) are statistically significant at the 1 percent level after adjustment. A similar reduction occurs in the number of lenders with at least one loan product with a statistically significant minority-nonminority difference-the matching procedure reduces the number of lenders almost 50 percent (data not shown in tables). 
14. Distribution of the difference between denial rates on applications by black and Hispanic applicants as a group and such denial rates for non-Hispanic white applicants, by lender-product combination, 2004

Percent except as noted

\begin{tabular}{|c|c|c|c|c|c|c|c|}
\hline \multirow{3}{*}{ 'Typo of unadjusud diflerence: } & \multirow{3}{*}{$\begin{array}{l}\text { Number of } \\
\text { leuder-product } \\
\text { combinitions } \\
\text { betore } \\
\text { adjustmint }\end{array}$} & \multicolumn{6}{|c|}{ Distribution of percentage of leuder-product combinatious atter adjustmeut } \\
\hline & & \multicolumn{3}{|c|}{$\begin{array}{c}\text { Black and llispanic denial rate is higher } \\
\text { and diflerence is statistically significant. } \\
\text { by degree of signiticauce }\end{array}$} & \multirow{2}{*}{$\begin{array}{l}\text { Dititerence } \\
\text { is not } \\
\text { xtulisticially } \\
\text { signiticaut }\end{array}$} & \multirow{2}{*}{ 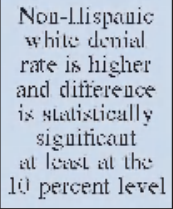 } & \multirow{2}{*}{ Lotal } \\
\hline & & 1 percint & 5 percent & 10 percent & & & \\
\hline \multicolumn{8}{|l|}{$\begin{array}{l}\text { Hiack aud Ilispanic denial rate is } \\
\text { higher and difference is statistically } \\
\text { itgnificunt }\end{array}$} \\
\hline 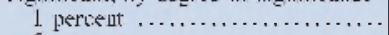 & 1,643 & 43.8 & 16.4 & 8.6 & 31.1 & (1) & $100 j$ \\
\hline 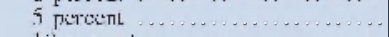 & 7.58 & 4.1 & 124 & 9.5 & 7401 & 0 & 100 \\
\hline lif perceut...$\ldots \ldots \ldots \ldots \ldots \ldots$ & 557 & .7 & 5.7 & 8.8 & 84.7 & i & 1010 \\
\hline $\begin{array}{l}\text { Differeuce is not statistically } \\
\text { thignificant }\end{array}$ & 10,185 & $\therefore$ & $4 \& .0$ & 1.0 & 98.1 & .4 & 100 \\
\hline $\begin{array}{l}\text { Non-llispanit white deuial rate is } \\
\text { highter and difference is statistically } \\
\text { signiticaut. by degree of siguiticauce }\end{array}$ & & & & & & & \\
\hline 1 perceint & 48 & 2.1 & $\hat{3} .1$ & 0 & 4.5 .8 & 5010 & 1010 \\
\hline 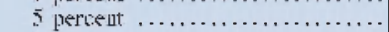 & 34 & j) & (i) & (i) & 94.1 & 5.9 & 1iij \\
\hline 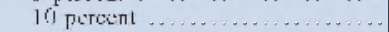 & 36 & 0 & 0 & (1) & 80.6 & 19.4 & 100 \\
\hline
\end{tabular}

NoTE: Includes transition-period applications (those submitted before 2004); for explanation, see text note 46 . The adjustment factors and the racial and ethnic categories differ from those in tables 9 through 13 . For explanation of

The effect of employing the statistical procedures is particularly dramatic for those products for which the black and Hispanic group shows an unadjusted incidence that is lower by a statistically significant amount. Only 7 percent of such cases remain statistically significant after the matching procedures are employed - and none are at the 1 percent significance level.

The reduction in the number of statistically significant differences results primarily from a reduction in the magnitude of the differences. For example, on average, the minority-nonminotily difference in the incidence of higher-priced loans for those lenderproduct combinations in which the unadjusted difference is positive and statistically significant falls 4.5 percent, or about one-fourth, after matching.

\section{Mean Pricing Spreads}

The matching procedure yields a similar reduction in the number of lender-product combinations showing a statistically significant difference in the mean spreads for blacks and Hispanics versus those for non-Hispanic whites. Of the 13,260 lender-product combinations, 5 percent show a statistically significant minority-nomminority difference in the mean spread; about one-third of these show a lower spread for blacks and Hispanics. The number of statistically significant differences for lender-product combinations is reduced 60 percent after the matching proce- adjustment tactors and for method of allocation into racial and ethnic cate-

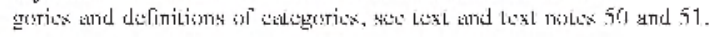

dure is employed, and about one-sixth of those show a lower spread for blacks and Hispanics. The number of lenders with a statistically significant difference in mean spread for at least one product also falls about 60 percent when adjustments are made.

\section{Overall Patterns}

A high degree of overlap exists among lenders with statistically significant adjusted differences between the minority and aonminority groups in denial rates, the incidence of higher-priced lending, and mean spreads. For example, 60 percent of the lenders with a difference in the adjusted mean spread that is statistically significant at the 1 percent level also have a statistically significant difference in the incidence of higher-priced lending for at least one product. Almost 80 percent of the lenders with an adjusted difference in the incidence of higher-priced lending that is statistically significant at the 1 percent level also have a statistically significant difference in the denial rates for at least one product. However, the presence of statistically significant differences in multiple outcome measures does not necessarily imply a more serious fair lending concern; it may simply reflect differences in the distribution of credit characteristics of the minority and nonminority populations served by the lender.

We emphasize that the Federal Reserve's statistical analysis system is only a screening tool. The HMDA 
15. Distribution of the difference between incidence of higher-priced loans for black and Hispanic borrowers as a group and the incidence for non-Hispanic white borrowers, by lender-product combination, 2004

Percent except as noted

\begin{tabular}{|c|c|c|c|c|c|c|c|}
\hline \multirow{3}{*}{ 'Т ype of unadjustad dillerence } & \multirow{3}{*}{$\begin{array}{l}\text { Number of } \\
\text { leuder-product } \\
\text { combiniations } \\
\text { betore } \\
\text { adjustumint }\end{array}$} & \multicolumn{6}{|c|}{ Distribution of percentage of leuder-product combiuations atter adjustment } \\
\hline & & \multicolumn{3}{|c|}{$\begin{array}{c}\text { Black and Lispauic iucidence is higher } \\
\text { and difference is statistically significant. } \\
\text { by degree of signiticauce }\end{array}$} & \multirow{2}{*}{$\begin{array}{l}\text { Difterence } \\
\text { is not } \\
\text { xtatisticially } \\
\text { signiticaut }\end{array}$} & \multirow{2}{*}{ 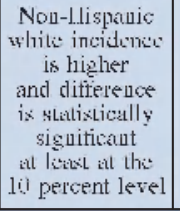 } & \multirow{2}{*}{ Liotal } \\
\hline & & I percent & 5 percent & 10 present & & & \\
\hline 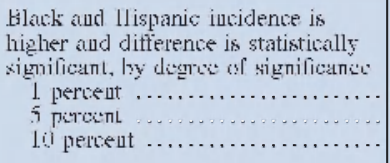 & $\begin{array}{l}537 \\
285 \\
241\end{array}$ & $\begin{array}{r}43.0 \\
4.0 \\
1.2\end{array}$ & $\begin{array}{r}1.5 .4 \\
11.9 \\
4.6\end{array}$ & $\begin{array}{l}7.5 \\
8.4 \\
9.1\end{array}$ & $\begin{array}{l}34.01 \\
74.7 \\
85.1\end{array}$ & $\begin{array}{l}0 \\
0 \\
0\end{array}$ & $\begin{array}{l}10 j 0 \\
100 \\
10 j\end{array}$ \\
\hline $\begin{array}{l}\text { Differeuce is not statistically } \\
\text { significant }\end{array}$ & 12,112 & .1 & .3 & .4 & 900 & .2 & 100 \\
\hline 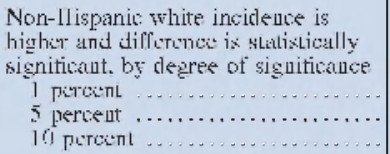 & $\begin{array}{l}33 \\
26 \\
31\end{array}$ & $\begin{array}{l}0 \\
0 \\
0\end{array}$ & $\begin{array}{l}0 \\
0 \\
0 \\
0\end{array}$ & $\begin{array}{l}0 \\
0 \\
0\end{array}$ & $\begin{array}{l}93.9 \\
961.2 \\
901,2\end{array}$ & $\begin{array}{l}6.1 \\
3.8 \\
9.7\end{array}$ & $\begin{array}{l}100 ? \\
100 j \\
100 ?\end{array}$ \\
\hline
\end{tabular}

NoTE: Excludes transition-period loans (those for which the application was submitted before 2004). The adjustment factors and the racial and ethnic categories differ from those in tables 9 through 13 . For explanation of adjustment

data alone, no matter how much they are manipulated, cannot be used to conclude whether a particular applicant was treated adversely on the basis of a prohibited factor regarding either the disposition of the application or the pricing of the loan. The data reveal little about an individual's financial circumstances and nothing about the condition or value of the property offered as collateral. Furthermore, the data reveal nothing about the underwriting standards used by a lender to assess the creditworthiness of an individual or to set loan price. Moreover, the data do not reveal how a lender's credit decisions relate to its overall business strategy. For example, the data do not account for the possibility that an institution's outreach efforts may attract a larger proportion of applicants with weaker credit profiles than do other institutions. Consequently, the data do not provide a final basis on which to draw conclusions regarding either the existence or the absence of fair lending violations.

\section{The Use of Screening in the Enforcement Process}

As implemented in the Federal Reserve's bank supervisory process, the statistical analysis system is used as a screening procedure to identify those institutions and their specific products that warrant closer review for fair lending concerns. Examiners familiar with the procedures and products of a given institution factors and for method of allocation into racial and ethuic catesories and detini-

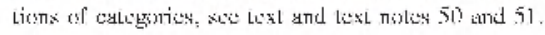

conduct the analysis and tailor it to the specific circumstances relevant to the institution in ways that reflect the institution's product offerings, its compliance risk-management systems, and the Federal Reserve's overall supervisory experience with the institution. Thus, the system used as a screening tool to analyze fair lending compliance for a particular institution is more complex than the streamlined analysis used in this article.

If an institution is targeted for more-intensive review, follow-up procedures can take one or more forms, including soliciting more information from the institution regarding its lending and underwriting procedures; gathering additional loan-level data, such as credit scores and loan-to-value ratios; performing detailed reviews of loan-file data; and conducting interviews with current or past bank personnel or borrowers. The follow-up can be integrated into the normal consumer examination cycle or can become a special review of fair lending compliance. The Federal Reserve has already applied the expanded statistical management system that includes the 2004 HMDA data to many of the institutions it supervises and has contacted those that exhibited relatively large pricing differences by race, ethnicity, or sex to learn more about their lending practices and to improve compliance oversight.

In addition, a review of the 2004 data by other agencies is under way. The Federal Reserve is sharing the screening procedures with other agencies so that, if they wish, they may integrate them into their 
16. Distribution of the difference between mean APR spread of prices for loans above the threshold for black and Hispanic borrowers as a group and the mean spread for non-Hispanic white borrowers, by lender-product combination, 2004 Percent except as noted

\begin{tabular}{|c|c|c|c|c|c|c|c|}
\hline \multirow{3}{*}{ 'Typo of unidjusked di iferenes } & \multirow{3}{*}{$\begin{array}{l}\text { Number of } \\
\text { leuder-product } \\
\text { combinitions } \\
\text { betore } \\
\text { adjustumint }\end{array}$} & \multicolumn{6}{|c|}{ Distribution of percentage of leuder-product combinations after adjustmeut } \\
\hline & & \multicolumn{3}{|c|}{$\begin{array}{l}\text { Black and llispanic mean spread is higher } \\
\text { and dilfurenet is statistically significant. } \\
\text { by degree of signiticauce }\end{array}$} & \multirow{2}{*}{$\begin{array}{l}\text { Ditterence } \\
\text { is not } \\
\text { xlatisticually } \\
\text { signiticaut }\end{array}$} & \multirow{2}{*}{ 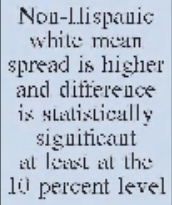 } & \multirow{2}{*}{ lintal } \\
\hline & & 1 percent & 5 percent & 10 percent & & & \\
\hline 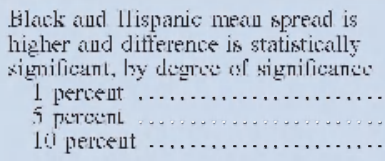 & $\begin{array}{l}173 \\
145 \\
127\end{array}$ & $\begin{array}{r}28.5 \\
5.5 \\
4.7\end{array}$ & $\begin{array}{r}18.6 \\
8.3 \\
63\end{array}$ & $\begin{array}{l}6.4 \\
9.0 \\
7.1\end{array}$ & $\begin{array}{l}40.7 \\
77.2 \\
81.9\end{array}$ & $\begin{array}{l}0 \\
0 \\
0\end{array}$ & $\begin{array}{l}100 j \\
100 \\
1010\end{array}$ \\
\hline $\begin{array}{l}\text { Differeuce is not statistically } \\
\text { significanl }\end{array}$ & 12,611 & .1 & .2 &..$^{3}$ & 09.3 & .2 & 100 \\
\hline 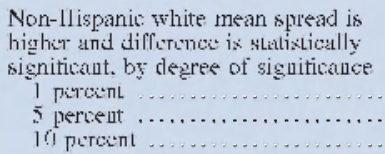 & $\begin{array}{l}75 \\
57 \\
73\end{array}$ & $\begin{array}{l}1.3 \\
1.8 \\
0\end{array}$ & $\begin{array}{l}1.3 \\
1.8 \\
0\end{array}$ & $\begin{array}{l}0 \\
0 \\
1.4\end{array}$ & $\begin{array}{l}84.0 \\
91.2 \\
97.2\end{array}$ & $\begin{array}{r}1.3 .2 \\
5.3 \\
1.4\end{array}$ & $\begin{array}{l}100 ? \\
1010 \\
100\end{array}$ \\
\hline
\end{tabular}

NotE: For definition of APR spread, see table 7, note 1. See also note to table 15.

supervisory programs. It is also responding to agency requests for additional, more detailed analysis of individual institutions that may be of concern to the agencies.

\section{Follow-Up Procedures When Unexplained Differences Are Found}

Experience with fair lending reviews indicates that widely used and largely noncontroversial, objective underwriting factors, such as credit scores and loanto-value ratios, can often account for some or perhaps all of the pricing differences by race, ethnicity, and sex that are not explained by the HMDA data. Thus, generally the first step in a compliance examination in which pricing differences are at issue is to gather additional information on the factors that are used in underwriting and pricing but that are not included in the HMDA data. These factors can vary from institution to institution and from product to product. This step is generally taken after consultation with the lending institution and after a review of its underwriting policies and procedures. If accounting for these objective factors explains all racial or ethnic pricing differences remaining after controlling for HMDArelated factors, the examination will typically be closed unless other pricing issues remain. If, however, not all differences can be explained by controlling for these factors, further steps will typically be taken.

Ordinarily examiners will ask the institution to provide any evidence it has for the remaining differ- ences. Supervisory experience shows that these differences frequently arise in institutions that employ discretionary pricing programs. Lenders who indicate to examiners that pricing differences are the result of either (1) the use of discretionary pricing to adjust for varied market factors, such as a competitor's pricing or individualized credit-risk or pricing-related factors not encompassed in a rate sheet, or (2) differences in the extent to which borrowers negotiate for the best available pricing on their loans should expect to be asked to provide credible evidence to support such explanations. Such evidence could include contemporaneous documentation from loan files, credible statements by participating loan personnel, and nondiscriminatory underwriting policies and procedures, such as internal audits of discretionary pricing patterns or training that focuses on a loan officer's responsibility to avoid setting pricing overages according to the perceived susceptibility of a given group to such pricing.

A particularly complex arena in which evidence of pricing differences may arise involves institutions having multiple loan origination channels, particularly channels that involve indirect loans (for example, those supplied by brokers or wholesalers). These channels can include multiple origination sources within a particular institution, including the institution's own loan officers along with those of its affiliates or subsidiaries, as well as indirect lending in which an institution originates loans referred to it by brokers or loan correspondents or purchases loans or pools of loans from unaffiliated, third-party origina- 
tors. Such channels can encompass significant variety in the nature of the relationships between a given lender and the affiliates, brokers, or third-party originators that deliver loans to the lender. Indeed, such relationships may range across a spectrum from a prime-rate lender that also operates a subprimc business in the same geographic market through a direct subsidiary to a regional bank in one section of the country that makes fully "arm's length" purchases of closed loans from an unaffiliated mortgage company operating solely in a different area.

From a fair lending perspective, a lender whose different channels of lending serve either borrowers or geographic areas that differ by race, ethnicity, or other prohibited characteristic is likely to be further reviewed. That will certainly be the case if these different channels produce loan pricing that also differs by race, ethnicity, or other prohibited characteristic $^{52}$ 'A full review of fair lending compliance in multiple-channel situations will turn on complex factual analyses that are beyond the scope of this article. It is sufficient to note here that such analyses will cover the type and degree of pricing differences, the nature of the various channels, the lender's legal and business relationships with other entities (for example, affiliates, brokers, correspondents, or wholesalers), the lender's business or economic basis for operating through those channels, and the lender's explanation for the pricing differences.

The process of examining an institution for which pricing differences based on race, ethnicity, or sex are statistically significant and for which purely objective pricing factors, such as credit scores or loan-to-value ratios, cannot explain the differences, will include a review of loan files; discussions with management or loan personnel about possible reasons for the differences; a review of evidence put forth to support their explanations; interviews with customers, where necessary, regarding their experiences with the lender; and a careful vetting of an institution's policies and procedures and actual practices. If, after conducting an examination, there is no credible nondiscriminalory explanation for such differences, examiners will consider what supervisory action will be appropriate to address the issue. Moreover, a lender that cannot account for differences in pricing across groups may also be exposed to private rights of action under

52. The expanded IIML $\triangle$ data can be: used to roughly difterentiats the pricing of an institulion's retail lenting operations from the pricing of loans obtained from olher chanmels by comparing the locations of borrowers with the locations of an institution's assessment artas. Loans outside an institution's assessment areas are mors likely to have been initiated by third-parly brokers or through other inclirect channels. applicable fair lending laws and may face adverse effects on its reputation.

\section{HOEPA Enforcement}

For the agencies that evaluate compliance with HOEPA, the expanded HMD'A data provide the first opportunity to readily identify which lenders extend home loans subject to that law and to measure the extent of their involvement in such lending. The new information also provides examiners with the data needed to efficiently select samples of loan files for review. The data can also be used to examine patterns of HOEPA-related lending across borrowers and neighborhoods, arrayed by their racial and ethnic profiles. Such analysis may reveal possible fair lending issues and may indicate communities where credit counseling activities could be targeted.

The Federal Reserve's statistical analysis system has been augmented to include several screens to aid HOEPA-related enforcement. These screens include the identification of HOEPA loans that are potentially unaffordable given a comparison of the applicant's income and the estimated monthly loan payments, the identification of loans with APR spreads that would appear to have triggered HOEPA coverage but were not reported as such, and the calculation of differences across racial and ethnic groups in the incidence of HOEPA lending. ${ }^{53}$

\section{SUMMARY AND CONCLUSIONS}

In 2002 the Federal Reserve Board amended its Regulation $\mathrm{C}$ to expand the types of information that lenders covered by HMD'A must disclose to the public about their home-lending activities. The amendments are intended to improve the quality, consistency, and utility of the reported data and to keep the regulation in step with recent developments in homeloan markets. Data reported for 2004 are the first to reflect the changes in the reporting rules.

'As anticipated, the expanded data provide new opportunities to assess home-lending activity. Newly available information on lien status and on whether a loan is for a site-built or manufactured home, as well as more uniformity in the information on homeimprovement and refinancing loans, allows analyses that are more relevant to the current state of the

53. The stimated monthly loan payment is derived from IIML $A$ data using the reported loan amount and an estimated $A P^{P} R$ that assumes a fixed-rate thirly-year loan. 
market. Most prominently, the new information provides the first publicly available loan-level information on loan pricing in the higher-priced segment of the home-loan market, a segment that was virtually nonexistent a decade or so ago but is now an important part of the overall home-loan market.

This article presents an analysis of the 2004 HMDA data. The analysis is conducted with the national HMDA database and is designed to provide an understanding of the overall patterns in the data rather than patterns that pertain to any individual market or lender. Much of the presentation focuses on the new items in the data. On balance, the analysis suggests that the information on lien status, manufactured homes, requests for pre-approval, and refined product definitions provides a much improved basis for describing lending activity and the disposition of applications for credit. Much of the initial public review of the data will, however, undoubtedly focus on loan pricing and particularly on the incidence of higher-priced lending and the comparison of prices paid by borrowers grouped by race, ethnicity, and sex.

The most likely initial public focus will be on the incidence of higher-priced lending among minorities (particularly blacks) and among non-Hispanic whites. In the raw data, the differences between these two groups in the incidence of higher-priced lending are generally more than 20 percentage points for various loan products. Our analysis shows, however, that more than two-thirds of the aggregate difference in the incidence of higher-priced lending between black and non-Hispanic white borrowers can be explained by differences in the groups' distributions of income, loan amounts, other borrower-related characteristics included in the HMDA data, and the choice of lender. Further, analysis at the level of individual lenders suggests that about 2 percent of the 8,853 lenders covered by HMDA exhibited a statistically significant difference in the incidence of higher-priced loans between black and Hispanic borrowers, on the one hand, and non-Hispanic white borrowers, on the other, after accounting for factors included in the HMDA data.

Thus, we see a sizable narrowing, at both the aggregate and institution levels, in the unexplained differences in the the incidence of higher-priced lending between minority and nomminority groups. This narrowing suggests that controlling for credit-related factors not found in the HMDA data, such as credit history scores and loan-to-value ratios, might further reduce unexplained racial or ethnic differences. Whether controlling for such additional factors will completely account for all remaining differences is unclear. In that regard, our collaborative study with the Credit Research Center on the lending activities of eight large subprimc lenders, reported here, suggests that controlling for credit-related factors not included in the data can make a difference. Our analysis demonstrated that for some products the racial or ethnic differences were fully accounted for, whereas for other products, unexplained differences remained. Clearly, reaching convincing conclusions about whether institutions treat individuals differently on a prohibited basis requires institutionspecific analysis.

Hence, our analysis strongly indicates that the raw data alone can lead to inaccurate conclusions, which in turn may be unfair to particular institutions and may lead to unnecessary restrictions on the availability of loans to less-creditworthy applicants. Riskbased pricing has greatly expanded the availability of home loans to borrowers who, because of weaknesses in their credit profiles, had previously been unable to qualify. It would be unfortunate if unwarranted accusations of illegal bias, stemming from improperly analyzed pricing differences, discouraged lenders from participating in this segment of the market.

The primary responsibility for ensuring compliance with fair lending laws falls on lenders. HMDA data may help lenders analyze and monitor their lending patterns. In addition, the regulatory agencies use the data for screening purposes to identify individual lenders that warrant heightened scrutiny regarding their loan-pricing activities. Where warranted, such reviews include gaining a fuller understanding of the institution's loan-pricing practices, analyzing loan-level data, and interviewing appropriate personnel to determine whether pricing differences identified through the HMDA screening process are explained by controlling for these additional data or by other objective factors.

To improve its fair lending examination capabilities, the Federal Reserve has modified its statistical analysis tool to use the new data to screen institutions for significant differences in lending outcomes across borrowers grouped by race, ethnicity, or sex. The Federal Reserve has already applied this expanded statistical management system to many of the institutions it supervises. It has also contacted those institutions that exhibit relatively large pricing differences to learn more about their lending practices and to improve its compliance oversight. Moreover, a review of the 2004 data by other agencies is under way, and the Federal Reserve is sharing the screening procedures with other agencies to facilitate their efforts. 
Institution-specific evaluations, which are not possible with the HMDA data alone, are essential to determining whether loan-pricing differences in fact reflect discriminatory treatment of minority groups. However, the aggregate data can nonetheless provide valuable, broader insights into the experience of such groups in the home-loan market. For example, black and Hispanic borrowers taken together are much more likely than non-Hispanic white borrowers to obtain credit from institutions that report a higher incidence of higher-priced loans. On the one hand, this pattern may be benign and reflect a sorting of individuals into different market segments by their credit characteristics. On the other hand, it may be symptomatic of a more serious issue. Lenders that report a lower incidence of higher-priced products may be either less willing or less able to serve minority neighborhoods. More troubling, these patterns may stem, at least in part, from borrowers being steered to lenders or to loans that offer higher prices than the credit characteristics of these borrowers warrant. Reaching accurate determinations among these alternative possible outcomes is one goal of the supervision system. Moreover, we hope that future research using the new HMDA data will provide insights that will facilitate this process.

\section{APPENDIX: ENHANCED DATA ON PRIVATE MORTGAGE INSURANCE}

Historically, mortgage lenders have required prospective borrowers to make a down payment of at least 20 percent of a home's value before they will extend a home-purchase loan. Such down payments are required because experience has shown that homeowners with little equity are substantially more likely to default on their mortgage. Private mortgage insurance (PMI) emerged as a response to both creditors' concerns about the elevated credit risk of lending backed by little equity in a home and the difficulties that some consumers encounter in accumulating sufficient savings to meet required down-payment and closing costs.
PMI protects a lender if a borrower defaults on a loan: It reduces a lender's credit risk by insuring against losses associated with default up to a contractually established percentage of the claim amount. The costs of the insurance are typically paid by the borrower through a somewhat higher interest rate on the loan.

In 1993 the Mortgage Insurance Companies of America (MICA) asked the Federal Financial Institutions Examination Council (FFIEC) to process data from PMI companies on applications for mortgage insurance and to produce disclosure statements for the public based on the data ${ }^{5+}$ The PMI data largely mirror the types of information submitted by lenders covered by HMDA. However, because the PMI companies do not receive all the information about a prospective loan from the lenders seeking insurance coverage, some HMDA items are not included in the PMI data. In particular, loan-pricing information, requests for pre-approval, and HOEPA status are unavailable in the PMI data.

For 2004 the seven PMI companies that were writing private mortgage insurance submitted data to the FFIEC through MICA. In total, these companies acted on nearly 2 million applications for insurance: 1.3 million to insure mortgages for purchasing homes and about 650,000 to insure mortgages for refinancing existing mortgages. PMI companies approved more than 90 percent of the applications they received. Approval rates are high because lenders are familiar with the underwriting standards used by PMI companies and generally submit applications for insurance only if the applications are likely to be approved.

54. Iounded in 1973, MICA is the trade association for the PMI industry. The FFFFC. prepares disclosure slalements for each of the PMI companies. The statements are available at the corporate huadquarters of ach company and at a contral dopository in cash MSA in which HMT)A data are held. The eentral deposilory also holds aggregate tala for all the PMT companies active in that MSA. Tn atdilion, the P.MI data are avalable from the I coderal keserve Board through its HMT)A Assislance T ine (202-452-2016). 